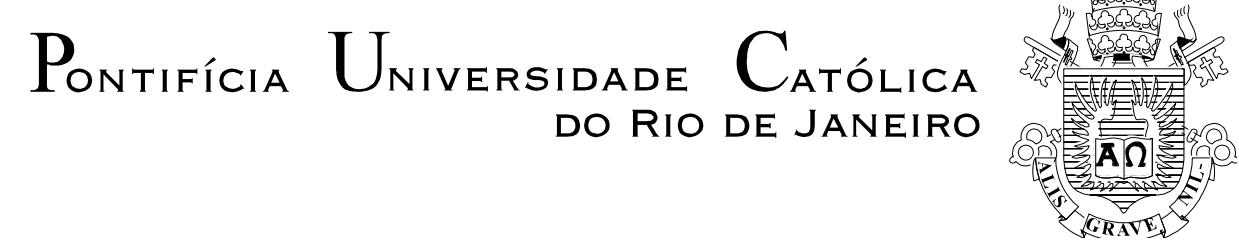

Priscila Andrade Magalhães Rodrigues

\title{
Diurno e noturno. \\ Desigualdades de origem e de formação entre estudantes de um curso de pedagogia
}

\section{Tese de Doutorado}

Tese apresentada ao Departamento de Educação da PUC-Rio como requisito parcial para obtenção do título de Doutora em Ciências Humanas/ Educação pelo Programa de Pós-graduação em Educação da PUC-Rio.

Orientadora: Rosaly Hermengarda Lima Brandão 


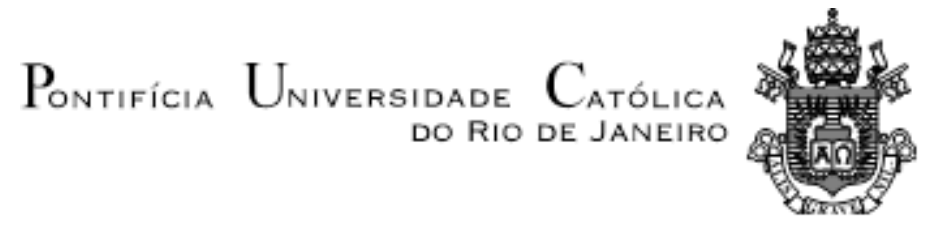

Priscila Andrade Magalhães Rodrigues

\author{
Diurno e noturno. \\ Desigualdades de origem e de formação entre \\ estudantes de um curso de pedagogia
}

Tese apresentada ao Departamento de Educação
da PUC-Rio como requisito parcial para obtenção
do título de Doutora em Ciências Humanas/
Educação pelo Programa de Pós-graduação em
Educação da PUC-Rio.

Prof ${ }^{a}$. Rosaly Hermengarda Lima Brandão

Orientadora

Departamento de Educação - PUC-Rio

Prof $^{a}$. Alicia Maria Catalano de Bonamino

Departamento de Educação - PUC-Rio

Prof $^{\mathrm{a}}$. Isabel Alice Oswald Monteiro Lelis

Departamento de Educação - PUC-Rio

Prof $^{\mathrm{a}}$. Miriam Waidenfeld Chaves

UFRJ

Prof $^{a}$. Hustana Maria Vargas

UFF

Prof ${ }^{a}$. Denise Berruezo Portinari

Coordenadora Setorial do Centro de Teologia e Ciências Humanas

PUC-Rio

Rio de Janeiro, 30 de maio de 2014. 
Todos os direitos reservados. É proibida a reprodução total ou parcial do trabalho sem a autorização da universidade, da autora e da orientadora.

\section{Priscila Andrade Magalhães Rodrigues}

Cursou teologia na Faculdade Batista do Rio de Janeiro (2006) e pedagogia na Universidade do Estado do Rio de Janeiro (2009), onde foi bolsista de extensão e de estágio interno complementar. Em 2009, defendeu seu mestrado em educação brasileira, na Pontifícia Universidade Católica do Rio de Janeiro, com dissertação na área de formação de professores, sendo bolsista do $\mathrm{CNPq}$ durante todo o curso. Atualmente, atua como professora estatutária de educação básica no Colégio Brigadeiro Newton Braga (CBNB) e integra o Grupo de Pesquisas em Sociologia da Educação (SOCEd), coordenado por Zaia Brandão.

Ficha Catalográfica

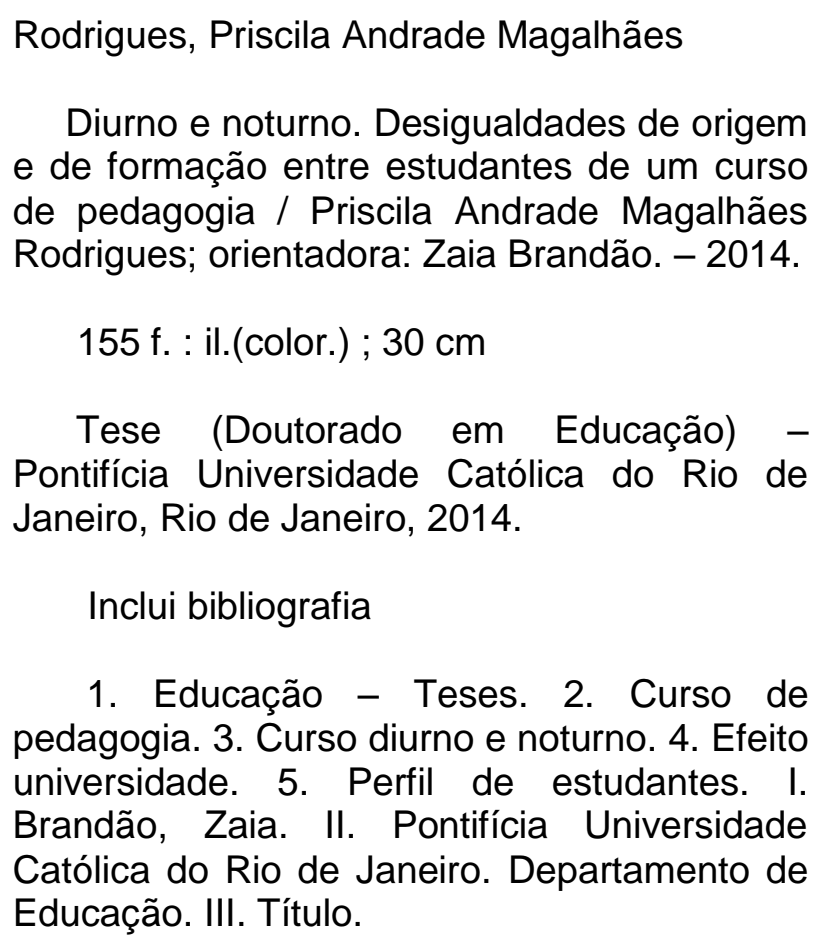

1. Educação - Teses. 2. Curso de pedagogia. 3. Curso diurno e noturno. 4. Efeito universidade. 5. Perfil de estudantes. I. Brandão, Zaia. II. Pontifícia Universidade Católica do Rio de Janeiro. Departamento de Educação. III. Título.

CDD: 370 


\title{
Agradecimentos
}

\begin{abstract}
A Deus, pela graça da vida.
Ao querido Felipe, pelo companheirismo e amizade.

Obrigada por estar sempre ao meu lado!

À minha querida mãe, pelo constante apoio, que, mesmo distante, sempre me encoraja a seguir em frente.
\end{abstract}

À Zaia, pela orientação, incentivo e apoio nesta caminhada.

Às prezadas professoras Alicia Bonamino e Hustana Vargas, que durante os dois exames de qualificação trouxeram inúmeras contribuições para a pesquisa.

\author{
À Andrea e Vanessa, sempre amigas. \\ À Liliane e ao Luís Paulo, cuja amizade, mesmo distante, \\ sempre se faz presente.
}

Ao casal Paula e Matteus, pela constante amizade.

A todos os queridos amigos que me acompanharam nesta jornada, seja no ambiente acadêmico, seja no ambiente escolar.

Ao Colégio Brigadeiro Newton Braga, por me conceder um precioso período de licença.

Ao SOCEd, pelo rico espaço de aprendizagem da pesquisa.

À CAPES e à PUC-Rio, pelo investimento em meus estudos. 


\section{Resumo}

Rodrigues, Priscila Andrade Magalhães; Brandão, Rosaly Hermengarda Lima. Diurno e noturno. Desigualdades de origem e de formação entre estudantes de um curso de pedagogia. Rio de Janeiro, 2014. 155p. Tese de doutorado - Departamento de Educação da Pontifícia Universidade Católica do Rio de Janeiro.

Esta pesquisa buscou verificar as diferenças entre os perfis e condições de trabalho/estudo dos turnos diurno e noturno de alunos do curso de pedagogia de uma instituição pública do estado do Rio de Janeiro. As condições de formação e de desenvolvimento do trabalho estudantil desses estudantes foram cotejadas através do olhar do próprio estudante e de seus professores. Procuramos caracterizar as possíveis diferenças de oportunidades de formação oferecidas nos dois turnos. Como já analisado pela literatura, estudantes de pedagogia são oriundos geralmente de estratos de camadas populares, e demandariam, portanto, condições humanas e materiais para maior dedicação e investimento no curso superior, de modo a contrabalançar as possíveis deficiências de sua formação básica. Realizamos entrevistas com 16 professores do curso de pedagogia da instituição pesquisada, aplicamos 334 questionários a estudantes de ambos os turnos, recebemos 57 relatos de estudantes sobre a sua experiência no curso e desenvolvemos 15 conversas informais com os estudantes dos dois turnos. Além deste material, procuramos caracterizar as condições de infraestrutura da universidade para o atendimento desses alunos, bem como o aproveitamento do curso e das oportunidades oferecidas pela universidade a eles. Os conceitos de habitus, capital cultural, trajetória e estratégia de Bourdieu foram fundamentais para este estudo. Apoiamo-nos ainda na bibliografia sobre qualidade da educação, tema investigado por duas décadas pelo SOCED, de cuja equipe faço parte. Em analogia aos estudos sobre o efeito escola, propusemo-nos a focalizar o efeito universidade. Neste sentido, o efeito universidade foi analisado a partir da organização dos processos acadêmicos, dos espaços universitários (bibliotecas, salas de estudo, áreas livres, etc), dos recursos de apoio acadêmico - conferências, eventos, bolsas de diferentes tipos (PIBIC, PIBID, de monitoria, de extensão...) - e do próprio "clima universitário" no sentido de ambiente favorecedor de atividades acadêmicas/culturais, sociais para os estudantes. Com este 
conjunto de elementos procuramos levantar algumas hipóteses sobre o efeito turno, identificando algumas diferenças que merecem uma maior reflexão sobre as desigualdades de oportunidades de formação entre os dois turnos.

\section{Palavras-chave}

Curso de pedagogia; curso diurno e noturno; efeito universidade; perfil de estudantes. 


\section{Abstract}

RODRIGUES, Priscila Andrade Magalhães; Brandão, Rosaly Hermengarda Lima (Advisor). Diurnal and nocturnal schedules. Inequalities of origin and training of students of a pedagogy course. Rio de Janeiro, 2014. 155p. Doctoral dissertation - Departamento de Educação da Pontifícia Universidade Católica do Rio de Janeiro.

This research analyzes the differences between the profiles and working/study conditions of diurnal and nocturnal schedules for students of pedagogy of a public institution in the state of Rio de Janeiro. The training and working development conditions of these students were collated through the eyes of the students themselves and their teachers. We have sought to characterize possible differences in training opportunities in both day and night schedules. As it has already been discussed in the specialized literature, pedagogy students generally come from lower class strata, and therefore these students require human and material conditions for greater commitment and investment in a higher education course in order to counterbalance the possible shortcomings of their basic training. 16 professors of pedagogy of the institution studied have been interviewed, 334 questionnaires to students in both diurnal and nocturnal schedules have been applied, 57 students have written reports about their experience in the course and we have had 15 informal conversations with students of the two schedules. In addition to this material, we have sought to characterize the conditions of the university infrastructure to treat these students as well as the use of the course and the opportunities offered by the university to them. Bourdieu's concepts of habitus, cultural capital, trajectory and strategy were essential for this study. We also base it on the literature on quality of education, a theme that has been researched for two decades by SOCED, whose staff I am part of. In analogy to the studies on the school effect, we have decided to focus on the university effect. Thus, the university effect has been analyzed from the organization of the academic processes of the university buildings (such as libraries, study rooms, open spaces, etc.), the academic support resources - conferences, events, scholarships of different types (PIBIC, PIBID, monitoring, extension...) - and the "university atmosphere" which promotes academic, cultural and social activities for students. With this set of 
elements, we have sought to raise some hypotheses about the schedule effect, identifying some differences that deserve further consideration of the inequalities in educational opportunities between those students who study in the morning and those ones who study in the evening.

\section{Keywords}

Pedagogy course; diurnal and nocturnal schedule; university effect; students' profile. 


\section{Sumário}

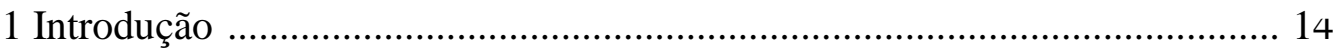

2 Construindo o objeto de pesquisa ....................................................... 18

2.1 Ressignificando uma temática que parece estar saturada ....................... 19

2.1.2 Qualidade da educação versus a carreira docente ............................... 21

2.1.3 Perfil dos estudantes versus condições de formação ............................ 25

2.1.4 Estudantes de cursos noturnos .......................................................... 28

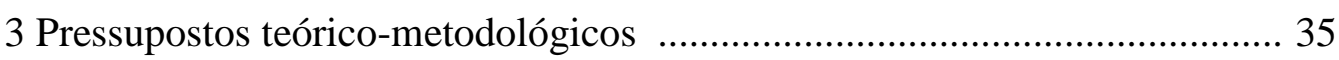

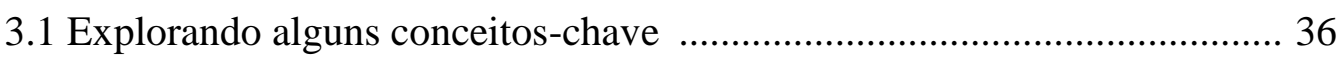

3.2 Estratégias de investigação/método ..................................................... 43

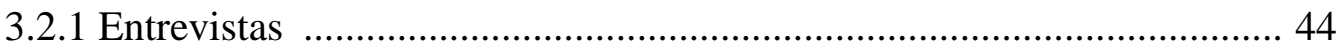

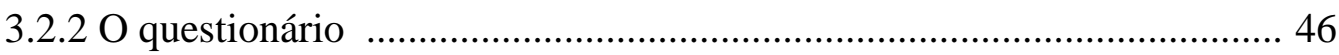

3.2.3 A aplicação dos questionários ............................................................ 49

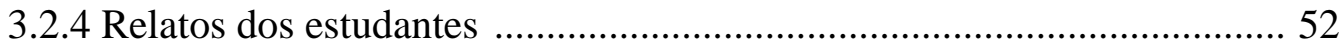

4 Perfil de estudantes e condições sociais de estudo ...................................... 53

4.1 Perfil dos estudantes de pedagogia da UERJ ........................................ 53

4.1.2 Situação socioeconômica ............................................................. 58

4.1.3 Trajetória escolar e escolha profissional ........................................... 67

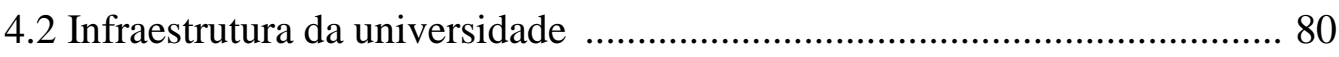

4.2.1 A Faculdade de Educação e o currículo de curso de pedagogia da

UERJ - Maracanã …........................................................................... 86 
4.2.2 Análise da grade curricular 96

4.3 Trajetória no curso de pedagogia: perfil acadêmico e condições para estudo 101

5 Entre a vivência da universidade e a vivência de um "aulão avançado"

5.1 O efeito universidade

5.2 Organização dos processos acadêmicos

5.2.1 Organização institucional e corpo docente

5.2.2 Alunos do curso noturno e o sentimento de discriminação

5.2.3 Ensino, extensão e pesquisa

5.2.4 Articulação entre universidade e escola de educação básica

6 Considerações finais

7 Referências bibliográficas 139

Anexos 146 


\section{Lista de quadros, mapas e tabelas}

Quadro 1 - Quadro-resumo dos conceitos dos itens do questionário dos estudantes

Quadro 2 - Alunos matriculados nas disciplinas em que foram aplicados os questionários $\mathrm{X}$ respondentes ............................................................ 50

Gráfico 1 - Percentual de respondentes por turno ...................................... 51

Tabela 1 - Faixa etária dos estudantes ........................................................ 54

Mapa 1 - Distribuição geográfica dos estudantes por turno ........................ 57

Tabela 2 - Situação de trabalho dos estudantes .......................................... 58

Tabela 3 - Área de trabalho dos estudantes .................................................. 59

Tabela 4 - Regime de trabalho dos estudantes ........................................... 60

Tabela 5 - Distribuição dos estudantes que realizam estágio ....................... 61

Gráfico 2 - Nível de escolaridade da mãe ................................................. 63

Gráfico 3 - Nível de escolaridade do pai .................................................. 63

Tabela 6 - Renda mensal da família ....................................................... 64

Tabela 7 - Principal responsável financeiro da família ................................ 65

Tabela 8 - Custeio dos estudos ............................................................. 66

Tabela 9 - Tipo de instituição onde cursou o ensino médio ......................... 67

Tabela 10 - Domínio de língua inglesa ....................................................... 68

Tabela 11 - Quero ser professor x Não sou professor atualmente ................. 70

Tabela 12 - Áreas em que nossos estudantes pretendem trabalhar ................ 74

Tabela 13 - Áreas em que nossos estudantes pretendem trabalhar dentro da educação ................................................................................ 75

Tabela 14 - Subáreas em que pretende trabalhar dentro da pedagogia .......... 76

Tabela 15 - Áreas em que se pretende trabalhar fora da pedagogia .............. 77

Gráfico 4 - Distribuição de horas-aulas entre as áreas de conhecimento do

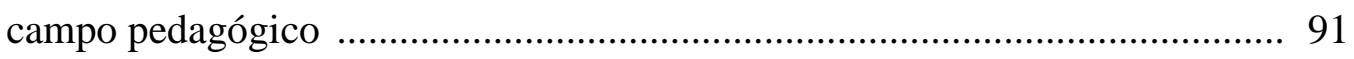

Quadro 3 - Grade de horários da UERJ .................................................. 94

Quadro 4 - Distribuição das disciplinas curriculares em áreas de

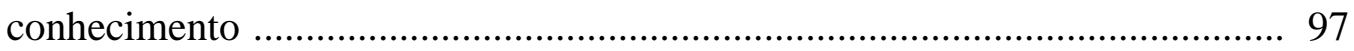

Tabela 16 - Tempo dedicado ao estudo acadêmico semanalmente ................. 102 
Tabela 17 - Dificuldades acadêmicas enfrentadas pelos estudantes

Tabela 18 - Participação nas atividades acadêmicas oferecidas pela universidade

Gráfico 5 - Participação nas diferentes atividades acadêmicas oferecidas pela universidade

Tabela 19 - Nível de exigência do curso

Tabela 20 - Nível de satisfação com o curso 


\title{
Introdução
}

\begin{abstract}
Apesar da urgência, é necessário que as pessoas possuam o tempo e as condições humanas e materiais para ir mais longe. O trabalho de formação deve estar próximo da realidade escolar e dos problemas sentidos pelos professores. É isto que não temos feito. Quando os professores aprendem mais, os alunos têm melhores resultados.
\end{abstract}

(Ann Lieberman)

Desde o curso de mestrado, minhas preocupações de pesquisa têm sido voltadas à formação dos professores das séries iniciais, em especial àquela oferecida pelos cursos de pedagogia. A formação que recebi durante minha graduação e licenciatura em pedagogia suscitou questões e dúvidas. Como seria alfabetizar crianças? Como ensinar tantos conteúdos e habilidades a elas, tendo estudado durante apenas um semestre disciplinas fundamentais, como processo de alfabetização, matemática, ciências, geografia e história, o que, em geral, era considerado insuficiente para a nossa formação, inclusive pelos nossos professores de pedagogia? Além dessas questões, percebíamos que o estágio supervisionado também não dava conta de fazer uma ponte entre os conhecimentos estudados na universidade e a prática de sala de aula.

No decorrer do curso de mestrado, participei da elaboração de uma proposta de estudo que buscava integrar todos os envolvidos no estágio supervisionado de duas licenciaturas - estagiários, supervisores de estágio e professores regentes -, em uma investigação em conjunto, para pensar e propor estágios mais participativos e que promovessem uma imersão mais profunda do estudante na escola. Os problemas que envolvem o estágio supervisionado, discutidos durante os encontros, me fizeram pensar sobre a minha própria e recente experiência de estágio vivenciada na graduação, o que me levou a refletir sobre esta experiência, buscando analisar como o estágio acontece na escola e qual a responsabilidade de cada pessoa envolvida no estágio supervisionado desses futuros professores.

Este estudo (Rodrigues, 2009) teve como principal contribuição o reconhecimento do lugar da escola de educação básica na formação de futuros 
docentes. A partir dessa experiência, professores da escola puderam, junto aos professores da universidade, contribuir para a formação desses futuros docentes. Os estagiários, por sua vez, tiveram a oportunidade de vivenciar uma experiência de imersão em seu futuro local de trabalho. Tal proposta possibilitou ainda, na visão de todos os envolvidos, uma melhor articulação entre a teoria estudada na universidade e a prática de sala de aula.

Agora, no doutorado, retomo minhas preocupações com o curso de pedagogia, no momento em que atuo como professora dos anos iniciais, e em um recorte de um amplo estudo do Grupo de Pesquisas em Sociologia da Educação (SOCED), da PUC-Rio, que tem investigado os cursos de pedagogia do Estado do Rio de Janeiro.

Hoje, há cinco anos atuando como professora da educação básica, percebo o distanciamento entre os problemas com os quais os professores são confrontados em sua prática de sala de aula, e a insuficiência da formação oferecida pelo curso de pedagogia. Realizando uma avaliação de minha própria formação, reconheço a importância de todas as disciplinas do curso, em especial, as de fundamentação assim como os estágios. Por outro lado, muitas discussões lá realizadas só vieram a ter sentido quando assumi a minha primeira turma, isto é, quando passei a operar com todos os conceitos estudados na prática docente diária. Foi somente nessa ocasião que consegui reduzir o gap existente entre a teoria e a prática. Esta situação evidencia o descompasso entre as discussões acadêmicas e as práticas escolares. Nem mesmo os estágios supervisionados conseguem realizar tal articulação, primeiro, porque geralmente eles são realizados ao final do curso; segundo, porque a maioria dos professores que os orientam não conhece a realidade da escola, em especial, a atuação docente nos anos iniciais, não conduzindo, portanto, o desejável processo de diálogo entre academia e escola.

Há, no entanto, outros fatores que dificultam a formação do estudante de pedagogia. De início, existem questões ligadas à própria origem do estudante, como sua trajetória escolar, suas vivências anteriores, bem como suas condições econômicas. Tais aspectos relacionam-se diretamente às condições que este estudante há de enfrentar (ou não) para se dedicar ao curso, pois elas decidirão se ele terá que trabalhar para se manter, se ele será capaz de realizar os estágios oferecidos na universidade, acadêmicos ou não, se poderá estudar na biblioteca, se 
participará dos eventos que acontecem na instituição de ensino superior, enfim, se poderá experimentar a vida universitária ou apenas conseguirá, com muito esforço, assistir às aulas. Outro fator de muita relevância na vida do estudante universitário é o fator institucional, ou seja, aquele ligado à infraestrutura da instituição de ensino superior e mesmo do próprio curso. Este último aspecto está ligado à oferta de recursos e serviços - como biblioteca, laboratórios de informática, refeitórios, atendimento ao estudante tanto com relação às questões burocráticas como para apoio acadêmico; à organização curricular do curso; à distribuição dos professores pelas disciplinas; à promoção de eventos, enfim, aspectos ligados a vida universitária.

Neste estudo, foco minhas análises sobre as condições institucionais, sociais e individuais nas quais se realiza a formação do estudante de pedagogia, numa perspectiva comparativa entre os estudantes do curso diurno e noturno da Universidade do Estado do Rio de Janeiro. Uma das hipóteses iniciais do estudo era a de que existiriam diferenças de perfis de estudantes nestes dois turnos que repercutiriam (positiva e negativamente) nesta formação. Observamos, no decorrer da pesquisa, que há alguma diferença entre o perfil desses estudantes. Entretanto, há ainda outro fator a ser considerado, que são as diferenças de oportunidades acadêmicas oferecidas pelo curso em análise ao corpo discente dos turnos diurno e noturno.

Enquanto egressa do curso analisado, pude compartilhar de inúmeras oportunidades acadêmicas e também de dificuldades enfrentadas por mim e meus colegas durante nossa formação. Como muitos estudantes, por exemplo, também migrei ao final do curso para o período noturno a fim de cursar disciplinas que não pude cursar no período a elas destinado, embora originalmente fosse matriculada no diurno. Ali vivenciei o "clima" de estudo que o aluno do noturno experimenta, que, como corroborado em entrevista por uma funcionária da biblioteca para esta pesquisa, trata-se de um clima mais corrido, mais apressado, mais objetivo, enquanto que pela manhã, podemos aproveitar melhor até mesmo os poucos espaços de convivência ofertados pela universidade. Enquanto aluna, conheci as rotinas do curso, os espaços físicos disponibilizados aos estudantes, os serviços da universidade. Voltar como pesquisadora exigiu um exercício de distanciamento que contribuiu para entender melhor o campo empírico de estudo. 
O relado desta pesquisa está divido em cinco partes. Após esta introdução, encontra-se o capítulo dois, onde mostramos os caminhos da construção do objeto de estudo, bem como realizamos uma revisão bibliográfica, que nos auxilia na construção de nosso objeto de pesquisa.

No terceiro capítulo, apresentamos nossos pressupostos teóricometodológicos.

O quarto capítulo faz referência aos dados encontrados, os quais estão divididos em três blocos de análise: a primeira parte contempla o perfil dos estudantes que fizeram parte de nosso estudo; o segundo bloco trata das questões de infraestrutura do curso analisado; e, por último, examinamos as condições de estudo apresentada por nossos estudantes.

No quinto capítulo, avaliamos as diferenças encontradas entre os dois turnos, destacando as implicações que tais diferenças possuem para a formação desses estudantes.

Por fim, no capítulo 5, elencamos as considerações finais a que chegamos com a pesquisa. 


\section{Construindo o objeto de pesquisa}

Atualmente, o SOCED está desenvolvendo um estudo com o objetivo de avaliar características de alguns cursos de pedagogia em universidades do Rio de Janeiro, focalizando "as condições de formação e do desenvolvimento do trabalho discente, tendo em vista os perfis, trajetórias escolares e condições de estudo" desses estudantes (Brandão, 2011).

Estudos revelam que as notas dos candidatos às vagas dos cursos de pedagogia estão entre as mais baixas dos vestibulares de todo o país, bem como que estes aspirantes à profissão docente estão situados nos níveis socioeconômicos (NSE) mais inferiores dentre os candidatos a vagas no ensino superior (Dias et al., 2008). Em sua maioria, os estudantes que ingressam no curso de pedagogia são oriundos de formação básica bastante precária, o que suscita a questão sobre em que medida o curso de pedagogia desenvolve estratégias para que seus estudantes superem as deficiências de sua formação anterior e se preparem adequadamente para assumir o magistério, estando aptos a promover um ensino de qualidade.

Este estudo dá continuidade à pesquisa desenvolvida pelo SOCED, que se dedicou a analisar durante uma década os processos de produção de qualidade de ensino, entre as melhores escolas do município do Rio de Janeiro no setor privado e público. Nosso objetivo com esta pesquisa foi, a partir de um recorte dos turnos diurno e noturno do curso de pedagogia da UERJ, cruzar os olhares dos estudantes e de seus professores sobre os processos e condições de formação desses alunos.

Inúmeras outras questões permeiam este estudo, a saber: quem são os estudantes que buscam o curso presencial de pedagogia da Universidade do Estado do Rio de Janeiro, do campus Maracanã, nos períodos diurno e noturno? Quais as razões que levam os estudantes a optarem pelo curso? O curso de pedagogia foi a primeira opção? Quais dentre estes estudantes desejam ser

professores? Qual a expectativa destes estudantes com relação ao curso? Como eles se percebem dentro da universidade? Quais as principais dificuldades 
enfrentadas? Como estes estudantes se mantêm no curso? Como estes alunos olham para a formação ali recebida? Quais condições (tempo, recursos financeiros, participações em atividades e programas oferecidos pela universidade) estes estudantes possuem para se dedicarem aos estudos? Como os professores veem os estudantes de pedagogia? Como os professores percebem a formação que o curso de pedagogia oferece a seus estudantes? Em que medida esses professores buscam estratégias em seus cursos (disciplinas ministradas) para tentarem superar as deficiências trazidas da formação básica que geralmente os estudantes possuem? Os professores do curso de pedagogia assinalam alguma diferença no perfil de estudantes nos dois períodos? Há diferenças entre os demais perfis de estudantes (como, por exemplo, os que fazem iniciação científica ou os que trabalham)? Há algum tipo de diferenciação de tratamento/estratégia de trabalho/currículo/avaliação, considerando as possíveis diferenças entre as condições de estudo do estudante do período diurno e noturno? Quais as principais dificuldades encontradas pelo professor de um curso de pedagogia?

Nosso estudo buscou, desse modo, assinalar as diferenças entre os perfis de estudantes do curso de pedagogia da UERJ do período diurno e noturno, bem como as condições de formação e de desenvolvimento do trabalho estudantil desses estudantes através do olhar do próprio estudante e de seus professores do curso de graduação. Buscamos ainda identificar, portanto, se existiriam diferenças de oportunidades de formação oferecidas aos alunos dos diferentes turnos.

\section{1}

\section{Ressignificando uma temática que parece estar saturada}

No levantamento de teses e dissertações que versam sobre o curso de pedagogia, no banco de teses da Capes, encontramos um número muito extenso e variado de trabalhos que normalmente se dividem em diferentes temáticas. Daquelas produções que versam sobre o perfil dos alunos e curso de pedagogia, 
verificamos que como analisado por Carrano $^{1}$ (2009), os estudos não avançam muito além de concluir que o curso é desprestigiado, de apontar para dificuldades enfrentadas pelos estudantes para se manterem no curso, de indicar a distância entre a teoria e a prática, e de tratar a relação entre aluno e professor. Carrano chega a dizer que a temática sobre a escolha do curso de pedagogia já está saturada. Além disso, os estudos coincidem ao reconhecerem que o curso de pedagogia, com maioria de mulheres, é um curso de segunda opção no vestibular, entendido como porta de entrada para o meio universitário. Encontramos ainda trabalhos que falam sobre representações sociais dos alunos que cursam pedagogia, sobre o perfil destes estudantes e suas condições de formação (Gatti e Barreto, 2008; Gatti, 2010). Mas há poucos estudos que realizam uma comparação entre os que estudam no diurno ou noturno, e quando há, geralmente tratam de cursos como, engenharia, administração, química (Dias et al., 2008; Peixoto, 2004, Faldini et al., 2003; Ferlin e Tozzi, 2005; Ruiz, 2004).

Por tal motivo, optamos pelo levantamento de estudos publicados em periódicos com recorte dos últimos dez anos, enfocando principalmente o perfil do alunado, a escolha da carreira docente pelos estudantes de pedagogia e os cursos diurnos e noturnos. A partir de alguns trabalhos, em especial daqueles que buscam traçar um perfil mais geral, como os levantamentos e estados da arte, buscamos alguns artigos citados pelos autores que vinham ao encontro de nossas questões de estudo, seguindo o que sugere Bourdieu (1996), de analisar a bibliografia, avançando a partir do levantamento de pesquisadores "mais avançados".

Entendemos que, embora nosso recorte esteja direcionado para as condições de formação de estudantes de pedagogia em seus respectivos turnos de estudo, nosso estudo localiza-se de modo geral no campo de análise dos perfis socioculturais e das condições de formação de jovens universitários. Este parece ser um aspecto pouco discutido na academia, já que segundo Carrano (2009, p. 181), há escassos trabalhos sobre "o fenômeno da mobilidade social e sobre como se dão as condições de experimentação da vida universitária após o ingresso". O autor ainda ressalta que um campo promissor para a pesquisa encontra-se

\footnotetext{
${ }^{1}$ Em estado da arte realizado sobre jovens universitários em teses e dissertações que tratavam de algum aspecto sobre o jovem nas áreas de educação, serviço social, ciências sociais, antropologia e política, entre os anos 1999 e 2006.
} 
na busca por saber como as instituições universitárias lidam com os diferentes capitais culturais de seus jovens estudantes. Que influências sobre as trajetórias universitárias estariam exercendo as distintas e desiguais condições de permanência na instituição? (idem).

Nosso estudo está situado especialmente nas condições dos cursos noturnos e diurnos de pedagogia em uma instituição de ensino pública, a Universidade do Estado do Rio de Janeiro, UERJ, campus Maracanã, percorrendo algumas percepções de professores e alunos desse curso.

\subsection{2}

\section{Qualidade da educação versus a carreira docente}

As políticas educacionais brasileiras dos últimos 15 anos parecem buscar meios de reverter o quadro de descaso com a educação, que historicamente resultou em baixa formação escolar. Uma das medidas foi a expansão do ensino fundamental gratuito, dos 6 aos 14 anos, que chega a patamares de universalização (Oliveira, 2007; Veloso, 2009). Contudo, o que se verifica é que uma parcela significativa das crianças desse nível de ensino não o conclui dentro da idade adequada. Por outro lado, "mais educação gera demanda por mais educação", como sugere Oliveira (2007, p. 686), o que levou a um aumento da demanda no país por ensino médio e mesmo por ensino superior. No entanto, o aumento da quantidade de alunos na educação básica não é acompanhado pela qualidade da educação, como se nota através do baixo rendimento de estudantes do ensino básico em avaliações como PISA, SAEB, Prova Brasil (Veloso et al., 2009). De modo semelhante, isso também se constata no ensino superior, em especial, nos cursos que preparam professores, como se observa nos estudos de Setton (1999), Peixoto (2009), Gatti e Barreto (2008), Dias et al. (2008), Gatti (2010). Esses estudos localizam os estudantes de cursos de formação de professores entre aqueles de menor nível socioeconômico e de menor nota de entrada no vestibular. 
Nos últimos anos, a principal questão da pauta das políticas educacionais tem sido a melhoria na educação. Inúmeras pesquisas vêm buscando identificar os fatores determinantes para uma educação que tem valor e consideram que a qualidade do professor é um item essencial. Menezes-Filho e Ribeiro (2009) verificaram em seu estudo a importância de um corpo docente qualificado, estável e assíduo, na variável escola, como responsável por melhores rendimentos de seus estudantes. Eles destacam ainda a necessidade de garantir que os melhores professores estejam na escola, tendo em vista que

a qualidade do ensino nas escolas públicas, que já era insuficiente, diminuiu ainda mais com a nova composição de crianças e professores que, em sua maioria, são oriundos de famílias com menos instrução e de camadas da sociedade com menor poder aquisitivo (Menezes-Filho \& Ribeiro, 2009, p. 172).

Com o propósito de organizarem sistemas de educação e de formação de qualidade, de modo a garantir elevados níveis de qualificação desde a educação básica e nos demais níveis de ensino, encontramos na literatura (Gatti et al. 2011; Ministério da Educação, Portugal, 2007) indícios de que só seremos capazes de garantir a qualidade da educação básica se os mecanismos de formação docente também forem de qualidade.

As pesquisas do SOCED que ao longo destes 10 anos se dedicam à análise das questões ligadas aos processos de produção de qualidade do ensino fundamental, tendo como campo empírico as melhores escolas nos níveis federais, municipais e privadas, também consideram a importância da formação docente e das condições do trabalho do professor para a produção da qualidade de ensino (Brandão, 2011).

A discussão sobre formação docente, porém, muitas vezes realiza um salto no debate, focalizando o professor a partir de sua formação inicial, sem considerar as questões que envolvem a escolha de jovens pela carreira docente, bem como sua precária formação básica que normalmente os acompanha, como se comprova nos baixos índices nos vestibulares daqueles que optam pelas licenciaturas (Gatti, 2009; Dias et al., 2008; Brito, 2007). 
Gatti (2009), em estudo sobre atratividade da carreira docente com estudantes de ensino médio, identificou certa relevância do magistério como função social para os estudantes entrevistados, considerando a profissão como nobre e gratificante. Entretanto, os estudantes ressaltam a desvalorização da profissão de professor, tanto social como financeiramente, destacando ainda as dificuldades que este profissional enfrenta em sua prática, por se tratar de um 'trabalho pesado', que consome muito o profissional, nas relações interpessoais. A pesquisa identificou uma preocupação dos estudantes ao escolher a carreira docente como opção profissional, ao haver uma "disparidade entre exigência e retorno, ou seja, os jovens falam do medo de trabalhar muito e não ser devidamente reconhecido" (Gatti, 2009, p. 42). Para os estudantes, essa atividade profissional parece muito árdua, quando comparada às suas necessidades e planos futuros.

\begin{abstract}
Árdua porque, apesar de transformadora e respeitável, exige uma forma de dedicação e um saber-fazer que ocupam completamente aquele que a ela se dedica, de modo a exigir demais e retribuir de menos. O exercício do magistério aparece como nobre e desejável, há reconhecimento e gratificação, por parte dos alunos, por esse ofício; mas tal sentimento de satisfação se mostra excessivamente intermitente e incontrolável para tornar-se um desejo/realidade por todos almejada ou mesmo suportada (idem).
\end{abstract}

Gatti et al. (2011) ressaltam o fato de o trabalho docente ser uma profissão de maior tensão que outras, ao exigir um compromisso contínuo do professor que não se esgota apenas durante o horário de trabalho. Além disso, as autoras destacam o alto grau de complexidade do trabalho deste profissional, "que implica, não só domínio de conhecimentos disciplinares e metodologias de ensino, mas também compreensões sobre o desenvolvimento cognitivo, afetivo e social das crianças e dos jovens, e compreensão e capacidade de lidar com diferenças" (Gatti et al., 2011, p. 137).

Para estes estudantes de ensino médio pesquisados por Gatti (2009), a profissão de professor está fadada ao desaparecimento, já que seus pais não querem que eles sejam professores, os pais de seus colegas também não querem, o que criaria um círculo vicioso. Tal situação exige, portanto, que a valorização da carreira docente esteja na pauta de discussões da política educacional, criando 
estratégias para que a profissão seja a opção profissional de jovens, em especial, que seja a preferência dos melhores. (Gatti e Barreto, 2008; Gatti, 2009; Gatti et al., 2011; Canário 2007, Ministério da Educação, 2007).

Considerando as características do trabalho docente, bem como sua importância, como salientaram os próprios estudantes da pesquisa citada (Gatti, 2009), Gatti et al. (2011, p. 138) entendem que por tal situação,

é que se vem colocando, com veemência, a necessidade de que a esse(a) profissional seja atribuído um valor diferenciado, constituindo-se uma verdadeira profissionalização para o professorado, para além de um ofício, com perspectivas atuais e futuras de reconhecimento, de remuneração digna, de sustentação de sua própria sobrevivência e de sua família, de condições dignas de trabalho.

A valorização da profissão do professor, com condições adequadas para o desenvolvimento de seu trabalho, é caminho para atender às demandas colocadas pelos jovens estudantes de ensino médio ao realizarem sua escolha profissional. Como Gatti et al. (idem) ressaltam, o "reconhecimento dos docentes da educação básica como profissionais essenciais ao país passa pela oferta de carreira digna e remuneração condizente com a formação deles exigida e ao trabalho deles esperado".

Mello e Rego (2004) ao darem um panorama sobre a formação de professores na América Latina e no Caribe sugerem ainda a necessidade de uma reinvenção da profissão docente de modo a contemplar a atual escola. As autoras apontam para a inadequada formação de professores - seja por lacunas que estes já carregam desde o ensino básico, seja pela má qualidade da maioria dos cursos de formação de professores - como um dos problemas que a escola e o professor enfrentam na tentativa de "atender com eficiência as necessidades de alunos de origens e interesses muito diversos" (Mello e Rego, 2004, p. 181). Ao levantarem estudos já desenvolvidos sobre a formação docente na América Latina e Caribe, Mello e Rego constatam que poucos são os estudos que se dedicam a examinar "o que é uma educação básica de qualidade, qual o perfil do professor que poderia assegurá-la e como deveriam ser os cursos de formação" que poderiam garanti-la (ibidem, p. 188). Numa perspectiva mais delimitada, nossa pesquisa optou por investigar as condições sociais e institucionais de formação e o perfil dos 
estudantes de pedagogia de cursos diurno e noturno, em uma das maiores e principais universidades públicas do Rio de Janeiro.

\subsection{3}

\section{Perfil dos estudantes versus condições de formação}

A questão sobre a atratividade da carreira docente tem sido bastante discutida no meio acadêmico. Em um balanço sobre as licenciaturas, Gatti e Barreto (2009) e Gatti (2010) já destacavam a importância de saber quem são os estudantes que optam pelos cursos de licenciatura. De suas considerações a partir de dados do ENADE 2005, com cerca de 137 mil estudantes de diferentes cursos de licenciatura, se lê que a razão para a escolha pelo magistério é de $65,1 \%$ entre os alunos do curso de Pedagogia, enquanto que para as demais licenciaturas essa porcentagem cai para 48,6\%. Cerca de $4,8 \%$ dos estudantes de Pedagogia afirmaram "não querer ser professor", enquanto que 13,3\% veem o curso como uma outra opção, caso não consigam exercer outro tipo de atividade profissional.

O estudo indica também que os estudantes de pedagogia são mais velhos se comparados aos estudantes das demais licenciaturas e se encontram fora da faixa etária considerada ideal para a formação (até 24 anos). Entre os estudantes, 22\% estão entre os de 25 a 29 anos, e 26,6\% estão entre os de 30 a 39 anos. Pouco mais de 53,3\% são solteiros, porcentagem que aumenta bastante entre os estudantes da licenciatura, 68,7\%. Como já sabido, a grande maioria é do sexo feminino $(92,5 \%)$.

Ainda de acordo com o estudo de Gatti e Barreto (2009) e Gatti (2010), quanto à situação econômica dos estudantes, boa parte se situa entre os que possuem renda familiar de até três salários mínimos $(41,9 \%)$ e de três a dez salários $(49,1 \%)$. Comparando com os dados que indicam a participação do estudante na renda familiar, percebemos que apenas $20 \%$ são totalmente custeados pela família, todos os demais trabalham ou exercem alguma atividade remunerada, e, desses, $41 \%$ contribuem ativamente para o sustento da família. $\mathrm{Ou}$ 
seja, cerca de $80 \%$ dos estudantes que cursam alguma licenciatura precisam trabalhar para se manter em seus estudos.

Essas informações revelam aspectos importantes sobre as condições de estudo desses futuros docentes, já que estudantes mais velhos possuem maiores responsabilidades financeiras e, no caso dos que trabalham, precisam se dividir entre trabalho, família e estudos, aspecto este com efeitos importantes sobre as condições de dedicação ao curso. Pude comprovar esta situação recentemente na condição de docente do curso em faculdade de pequeno porte. $\mathrm{O}$ fato de a idade de estudantes de pedagogia ser mais alta que a dos outros universitários (faixa etária de 18 a 24 anos) pode ser explicado também pela exigência de certificação superior de professores que já atuam na profissão e que possuem apenas a formação docente em ensino médio.

Este foi outro aspecto analisado nesta pesquisa, cuja hipótese era a de que o curso noturno normalmente fosse mais procurado por aqueles que já estão na profissão e que buscam a certificação para atenderem as exigências de sua atuação profissional ou mesmo para progressão na carreira docente, enquanto que no curso diurno, a maioria dos estudantes é recém-saída do Ensino Médio. Para muitos deles, o curso de pedagogia é uma porta de entrada ao ensino superior, uma “escolha pelo possível”, mesmo que não almejem atuar na docência.

Quanto à escolarização familiar, a maioria dos pais e mães dos alunos de pedagogia concluiu apenas a quarta série (atual $5^{\circ}$ ano), o que reflete diretamente no capital cultural/escolar desses estudantes. Gatti (2010) ressalta que esse aspecto indica que esses estudantes representam uma geração com formação bastante superior à de seus pais, sendo muitas vezes, os primeiros a alcançarem o ensino superior na família.

Vale destacar a contribuição dos estudos Gatti e Barreto (2009) e Gatti (2010) a esta tese, com a diferenciação do perfil daqueles que optam pelas licenciaturas. Uma ressalva a ser considerada é que nos estudos das autoras elas trabalharam com dados gerais de estudantes de pedagogia brasileiros de instituições públicas e privadas, sem diferenciação. Para efeito de comparação com nossos dados, este fator representa um complicador, já que minha pesquisa produziu dados de uma instituição pública. Por esta razão, consideramos nas análises, o caráter mais geral de seus resultados, sem comparações. 
Como assinala Ann Lieberman (1999), na epígrafe deste estudo, esses estudantes, geralmente de estratos populares, demandariam "condições humanas e materiais para irem mais longe", ou seja, demandariam condições de maior dedicação e investimento no curso superior, condições estas que a maioria não possui, de modo a contrabalançar as possíveis deficiências de sua formação básica.

Esses alunos que normalmente chegam à universidade com deficiências básicas na habilidade de leitura (Gimenes \& Pullin, 2010), escrita, matemática fundamental básica, e mesmo a habilidade oral, tão fundamental para a profissão de professor, necessitariam, portanto, de melhores condições humanas e financeiras para estudo (Neri, 2009; Tinto, 2004).

Tais condições, já suscitadas por Zago (2005) a partir de estudos voltados para as situações de estudantes universitários de camadas populares, são entendidas como tempo para leitura e releitura dos textos acadêmicos; relações com o meio de origem e meio universitário; hábitos de cultura e lazer; moradia; transporte; financiamento dos estudos (pois mesmo quando este é gratuito há inúmeros custos que precisam ser considerados); alimentação e saúde; bem como questões de infraestrutura oferecidas pela instituição de formação, tais como acesso a laboratórios de informática, à biblioteca, alimentação de baixo custo na própria universidade, acesso a eventos acadêmicos, entre outros.

Em estudo que buscou identificar fatores que promovem o sucesso e o insucesso escolar no ensino superior, Costa e Lopes (2009) elencam inúmeros aspectos que são considerados condições favoráveis à preparação de estudantes em formação superior. Essas condições são por eles chamadas de estruturas de apoio e são divididas em quatro "processos/momentos: (i) a atração e (ii) integração de novos alunos, (iii) o acompanhamento e (iv) a inserção profissional dos alunos" (Costa \& Lopes, 2009, p. 191). Neste sentido, a universidade promotora de condições favoráveis ao sucesso de seus estudantes já se apresenta aberta aos novos alunos, desde a clara divulgação de seus cursos, desenvolvendo portais com informações claras quanto ao acesso e organização interna da universidade; realizando encontros sobre métodos de estudo, gestão do tempo e recursos necessários ao ambiente universitário; apoio a estudantes com necessidades especiais; programas de tutorias (efetuadas por professores ou 
mesmo por alunos mais adiantados no curso), visando à integração dos novos estudantes; acompanhamento/orientação acadêmica dos estudantes, auxiliando-os em seu processo de aprendizagem; apoio pedagógico e psicológico; programas que detectem e acompanhem alunos com dificuldades de aprendizagem; assim como uma excelente estrutura física e de serviços como bibliotecas, salas de estudo, restaurante, etc. Todos esses serviços com horários adequados às necessidades dos estudantes contribuem para o sucesso destes no ensino superior. Os autores apontam ainda para experiências não necessariamente ligadas ao estudo, como a participação nos diretórios acadêmicos ou trocas internacionais entre estudantes, através de intercâmbio; e mesmo oferta de eventos acadêmicos e feiras de empregos. Esses são incentivos necessários à condição adequada de formação universitária.

\subsection{4}

\section{Estudantes de cursos noturnos}

A partir do levantamento em periódicos da área, percebemos que são escassos os estudos que se dedicam a comparar um curso ofertado em períodos distintos. Carrano (2009) identificou que não houve crescimento no número de estudos dedicados ao ensino noturno em comparação ao estado da arte anterior que analisou 1980-1998 (Spósito, 2002). Dos trabalhos existentes, há uma diversidade de cursos analisados, como administração, contabilidade, direito, química, engenharia, cujo enfoque se dá especialmente nas dificuldades de os estudantes conciliarem trabalho e estudo.

A expansão do ensino superior noturno é entendida para os estudiosos da área como uma forma de inclusão social (Dias et al., 2008). Comin e Barbosa (2011) e Gatti (2008) comprovam que houve um crescimento exponencial do ensino superior do país, em especial, dos cursos noturnos, que recebem cerca de $62 \%$ de todos os graduados. Dados do PNAD indicam que o maior crescimento do ingresso de estudantes no ensino superior se dá entre aqueles que trabalham mais de 40h semanais. 
Para Comin e Barbosa (2011) esse novo perfil de estudantes é explicado pela já inserção profissional desse indivíduo que busca na formação do ensino superior um meio de progredir e se manter no mercado de trabalho. Esse dado é corroborado, por exemplo, pelo aumento especialmente em profissões de professoras e enfermeiras, profissões que com mudança na legislação, passaram a exigir diplomas de nível superior para a atuação profissional.

Para os autores, o aumento de renda dos mais pobres, conjugada com políticas de inserção no ensino superior alavancou o aumento de estudantes que trabalham neste nível de ensino. Deste modo, aqueles que optam pelo curso noturno, são os que veem o estudo com otimismo - ao visualizarem impulso na carreira através de uma perspectiva financeira melhor, já que há prêmios salariais para cada nível de ensino cursado -, e também possuem condições de manterem os custos financeiros de estudar e a difícil tarefa de articular trabalho e estudo. Portanto, é provável que muitos desses estudantes procurem apenas a titulação e não tenham escolhido o curso com o objetivo de se tornarem professores.

Em estudo sobre o perfil dos candidatos que visam a uma vaga no curso superior da UFMG, Dias et al. (2008) buscou comparar os candidatos aos cursos diurnos e noturnos. Com relação ao perfil dos candidatos, notou-se que os que se buscam uma vaga nos cursos noturnos possuem nível socioeconômico inferior aos optam por tentar ingressar nos cursos diurnos, conforme também encontramos em Carrano (2009). Estes candidatos são oriundos em maior grau de escolas estaduais e demais públicas, enquanto que a maioria que decide pelos cursos diurnos é oriunda de escolas particulares, o que leva os autores a concluírem que o "curso noturno está atraindo candidatos com situação socioeconômica inferior" (Dias et al. 2008, p. 138). Para os autores, nos cursos noturnos as variáveis socioeconômicas possuem maior relevância em relação à possibilidade de aprovação, enquanto que, nos cursos diurnos, essa importância está ligada a variáveis relativas à formação do candidato, como por exemplo, escola em que estudou ou domínio de língua estrangeira. Percebe-se, por exemplo, que entre os estudantes com maiores e menores chances de aprovação no vestibular, os candidatos aos cursos noturnos, no quesito nota, sempre aparecem com percentual menor que o grupo geral de candidatos ou entre aqueles que fazem opção pelos cursos diurnos. 
Segundo os autores, todas as licenciaturas, com exceção de biblioteconomia, possuem candidatos com os menores índices de NSE em relação aos candidatos dos demais cursos, com destaque ao curso de pedagogia, que tem o mais baixo de todos os índices. Entre as licenciaturas, os estudantes com NSE menores estão entre aqueles que estudam em cursos noturnos. Entre os aprovados, há um ligeiro aumento do NSE, no entanto, esse índice fica bem abaixo, quando comparado com outros cursos de maior prestígio.

Com relação à raça e cor, Dias et al. (2008) indicam que há maior chance de aprovação para aqueles de cor branca, diferença esta que se acentua ainda mais em relação aos candidatos do curso noturno.

Outro fator interessante apontado pelo estudo diz respeito à localização geográfica de moradia e de estudo destes universitários. Os autores perceberam que os cursos noturnos tendem a atrair pessoas de regiões mais próximas à universidade. No caso específico da UFMG, "a maioria dos candidatos, tanto para os cursos noturnos quanto diurnos, mora em Belo Horizonte", ao passo que "os cursos noturnos atraem menos pessoas de fora da região de Belo Horizonte $-\mathrm{BH}$ - e Grande BH (Dias et al., 2008, p. 134)."

Em outro relatório comparativo entre cursos diurno e noturno da Universidade Federal de Minas Gerais (Peixoto, 2004), cujo objetivo foi o de identificar possíveis distinções entre os cursos, verificou-se que não há diferenças significativas entre o desempenho dos estudantes dos dois turnos no quesito nota. O estudo analisou o rendimento semestral dos estudantes, a integralização do curso no tempo proposto pela universidade, a participação dos estudantes nos programas de bolsas, o ingresso à pós-graduação e por fim a utilização do programa de assistência ao estudante na universidade. Com relação ao rendimento acadêmico na universidade e integralização do curso pelos estudantes, a autora não identificou aspectos muito díspares entre os dois turnos ${ }^{2}$. Neste estudo, os únicos fatores que refletiram uma diferença de comportamento entre os dois

\footnotetext{
${ }^{2}$ Entre os estudos por nós levantados, a diferença de rendimento foi encontrada especialmente nas áreas exatas (Viana et al. 1999; Faldini et al., 2003; Zanardi \& Lima, 2009). Percebeu-se ainda maior reprovação entre os estudantes do turno noturno. No estudo de Peixoto, a partir dos resultados do ENADE, verificou-se que, em geral, as notas dos estudantes do noturno variam em média 3\% entre os dois turnos, com vantagem para os estudantes do diurno. Matemática e ciências biológicas foram as áreas com maior diferenciação, $10 \%$ e 7\%; o curso de pedagogia teve variação de $5 \%$.
} 
turnos, foram os últimos dois aspectos. Fica evidente a desigual participação nos programas de bolsas oferecidos pela universidade entre os estudantes do curso noturno. Segundo a autora,

\begin{abstract}
isto pode se dar devido ao fato de que, no imaginário dos professores orientadores, os alunos do turno diurno seriam "naturalmente" voltados para uma formação acadêmica, concepção que é reforçada devido à grande maioria dos cursos noturnos oferecer apenas a modalidade licenciatura. Pode-se supor também que seus professores selecionam menos alunos do noturno por não confiarem na formação que lhes está sendo dada na graduação, situação que se deve à inserção desses docentes dentro da concepção do senso comum de que o curso noturno é de pior qualidade que o diurno. Considerariam eles, em decorrência, que aqueles alunos irão exigir mais do orientador e renderão menos na iniciação científica. (Peixoto, 2004, p. 14)
\end{abstract}

Com relação ao ingresso na pós-graduação, apesar da diferença entre os dois turnos, a autora reconhece que há uma boa porcentagem de estudantes de curso noturno que lá ingressam (cerca de $20 \%$, em comparação com os ingressantes oriundos de cursos diurnos).

O estudo verificou que cerca de $20 \%$ a mais dos benefícios oferecidos pelo programa de assistência da universidade, que distribui recursos entre os estudantes de acordo com sua renda, são utilizados pelos estudantes do curso noturno, o que, segundo Peixoto (2004), indica que estes estudantes possuem condições financeiras mais precárias que os estudantes do curso diurno.

Por fim, Peixoto (2004) conclui que outros fatores acadêmicos como o cumprimento da proposta curricular do curso e de seu conteúdo, os métodos pedagógicos dos professores, bem como os modos de avaliação demandariam uma melhor apreciação na tentativa de identificar diferenças entre os dois turnos, de modo a "adequá-los às necessidades da clientela diferenciada que eles contemplam" (Peixoto, 2004, p. 26). Ela propõe ainda que seja destinado um percentual de bolsas específicas a estudantes do curso noturno, de modo a garantir um padrão de participação comum entre estudantes do diurno e do noturno no que ela chama de "modalidade de atividade acadêmica" (ibidem, p. 27). Isso garantiria o acesso igual às oportunidades de participação nos programas de bolsas da universidade. 
Em estudo cujo objetivo foi o de analisar as práticas de avaliação do ensino-aprendizagem de estudantes de turnos diurno e noturno do curso de pedagogia, Carvalho (2012) identificou várias questões que contribuem para nosso estudo, em especial, ao traçar um perfil dos estudantes dos dois turnos e apontar para as dificuldades por eles enfrentadas.

Com relação à comparação entre os dois turnos, a autora encontrou diferenças entre currículo, carga horária, semestres para conclusão do curso que, entre os estudantes do noturno, é maior. A maioria dos estudantes observados pela autora, tanto do diurno como no noturno, ressalta que os principais fatores que dificultam o seu processo de aprendizagem é o cansaço físico e mental e a didática dos professores. Os estudantes do curso noturno identificam ainda o trabalho como fator prejudicial; entre estes, a autora conclui, no entanto, que não foi caracterizada desmotivação com o curso. Carvalho (2012) constatou que há maior empenho de alunos do curso noturno em encontrar formas de ultrapassar as adversidades inerentes à formação superior, "mostrando-se tão ou mais capazes que os alunos do turno diurno, inferindo-se, portanto, que as particularidades noturnas não se relacionam a incapacidades ou graus menores de formação" (idem, p. 136).

Entre os professores entrevistados pela autora, estes assumiram que exigem um pouco mais dos estudantes do turno diurno, por considerar que eles possuem mais tempo livre para estudar, bem como possuem condições de participar das atividades acadêmicas da universidade, como assumir bolsas de pesquisa, entre outras modalidades. Seus professores também ressaltaram que a falta de maturidade entre os estudantes do turno diurno interfere no comprometimento destes com sua formação, o que, segundo eles, se trata de um comportamento de estudantes do ensino médio. Para a autora, os professores reconhecem que as aulas precisam ser mais dinâmicas e intensivas no turno noturno. Mas, avaliam que o tempo da sala de aula é otimizado pelo esforço dos estudantes e sua experiência da vida, que os ajudam nas discussões em aula e na reflexão sobre os conteúdos.

Os estudantes do curso noturno reclamam da incompatibilidade de horário das disciplinas do curso, da falta de informações na universidade e de um currículo adaptado às suas necessidades. Para Carvalho (2012), aspectos ligados 
ao trabalho, carga-horária do curso reduzida, acesso aos setores administrativos da universidade também reduzidos, e tempo para se dedicar aos estudos são compensados pelo fato de o estudante do noturno ser um grupo mais maduro, que valoriza a formação universitária.

Entre os estudos que analisam o curso noturno de diferentes áreas disciplinares, apesar de algumas diferenciações próprias de cada curso, destaca-se que esse é constituído majoritariamente por um corpo discente na condição de aluno-trabalhador e que além do pouco tempo disponível, tais estudantes possuem pouco hábito de estudo (Viana et al., 1997). Faldini et al. (2003) identificou que os estudantes do curso noturno tendem a dedicar menos tempo médio semanalmente aos estudos que seus colegas do curso diurno; entretanto, em épocas de provas, esses tendem a estudar mais horas, o que pode revelar a necessidade de se tentar suprir a falta de estudo sistemática ao longo do curso. Os estudos identificam ainda que geralmente os cursos de bacharelado são ofertados no turno diurno, enquanto que as licenciaturas são disponibilizadas no noturno (Viana et al., 1997; Peixoto, 2004; Gatti, 2008).

A estrutura curricular do curso e os métodos de ensino dos professores são apontados como os principais fatores de desmotivação para o estudante. Para Ruiz (2004), os estudantes pesquisados gostariam que seu crescimento no curso fosse mais valorizado pelos docentes, indicando como estratégia dos professores para a motivação de seus alunos o apoio aos estudantes com relação à sua capacidade de desenvolvimento acadêmico.

Entre as estratégias para oferecer condições para o aluno do noturno aproveitar melhor seu curso, está o aumento do período de integralização do curso, de modo a evitar a sobrecarga de disciplinas e possibilitar que este estudante tenha tempo para utilizar recursos oferecidos pela universidade, realizar atividades de pesquisa e extensão, bem como ter tempo para executar seus trabalhos acadêmicos e usufruir de espaços como biblioteca e laboratórios para estudo (Viana et al., 1997). Ferlin e Tozzi (2005), ao investigarem a oferta de um curso de engenharia, ressaltam que, com o objetivo de garantir a qualidade dos dois cursos, a universidade busca manter os mesmos professores lecionando as mesmas disciplinas de manhã e à noite, o que garante, segundo eles, os mesmos conteúdos, programas e professores dos dois cursos (Ferlin \& Tozzi, 2005). Os 
autores mencionam também que cursos de extensão são criados na tentativa de auxiliar os estudantes nos conteúdos de maior dificuldade. Tais cursos, ofertados durante todo o ano, são realizados em diferentes dias da semana e horários, inclusive aos sábados, de forma que estudantes dos dois turnos possam frequentálos. Há também a manutenção de laboratórios e bibliotecas abertos até após o horário do turno da noite, até às $23 \mathrm{~h}$, além dos sábados, de sorte que os estudantes do noturno pudessem se servir destes espaços.

No geral, entre os pesquisadores que se dedicam a estudar os cursos noturnos, é praticamente unânime a concepção de que estes alunos demandam a realização de estratégias diferenciadas, tanto por parte da equipe docente e do próprio estudante, como também de aspectos ligados à organização do próprio curso de nível superior para o melhor aproveitamento destes (Viana et al., 1997; Ruiz, 2004; Faldini et al., 2003; Peixoto, 2004; Carvalho, 2012).

Esses dados indicam que há peculiaridades no perfil de estudantes de cursos diurnos e noturnos que merecem ser analisadas, visto que perfis diferentes de estudantes demandariam estratégias formativas específicas. Nossa hipótese inicial sugeriu que as condições de formação e de estudo desses estudantes são diferenciadas, mesmo em uma mesma instituição. Buscamos assim analisar as condições, processos e estratégias de formação desses estudantes do curso noturno, comparados aos estudantes de curso diurno, de uma mesma instituição. 


\section{Pressupostos teórico-metodológicos}

Inspirados por Costa e Lopes (2009) e Cazelli (2005), decidimos elaborar um quadro de referência teórico-metodológico a partir de três blocos de análise de nosso estudo, a saber: condições de origem social/perfil do estudante; condições institucionais do curso noturno e diurno de pedagogia; e condições para estudo do estudante. Cada um desses três blocos de análise é pautado em conceitos que estão diretamente ligados ao nosso objeto de estudo, logo, compondo nossos pressupostos teórico-metodológicos. Cada bloco permitirá cotejar as condições de formação dos estudantes dos dois turnos do curso estudado, possibilitando caracterizar as especificidades de cada turno. O material empírico coletado faz parte da pesquisa mais ampla desenvolvida pela equipe SOCED.

\section{I - Perfil do estudante de Pedagogia}

Este bloco analisa as condições de origem social do estudante, como sua trajetória na educação básica, seu capital socioeconômico, escolar e cultural; além de observar suas estratégias de entrada no ensino superior e reavaliar até que ponto sua opção pelo curso de pedagogia seria uma "escolha do possível"?

\section{II - Condições de infraestrutura da universidade, ou seja, do curso de pedagogia}

Este bloco abarca todas as condições físicas e organizacionais que a universidade oferece ao estudante. Os aspectos a serem considerados são os espaços como a biblioteca, o laboratório de informática; outros laboratórios específicos; a existência de restaurantes a custo baixo para o aluno; salas de estudo (horários adequados para o atendimento dos estudantes, bem como condições físicas foram aspectos observados); apoio pedagógico ao estudante, como por exemplo, atendimentos psicológicos, auxílio na criação de estratégias de 
estudo, programas de tutorias; disponibilidade aos alunos dos materiais de estudo, como artigos, excertos bibliográficos, apostilas, entre outros; atendimento adequado nas questões administrativas; atendimento ao aluno pelo professor quando necessário; oferta de bolsas/apoio para estudos; entre outros.

\section{III - Condições para estudo, ou aproveitamento do curso pelo estudante}

Este aspecto busca analisar como o curso de pedagogia é vivenciado pelo estudante. Este fator é medido através da análise sobre a disponibilidade de tempo para estudo; dificuldades encontradas (financeiras, falta de base escolar do estudante, etc.), bem como pelo aproveitamento dos estudantes das oportunidades oferecidas pela universidade, como bolsas e demais atividades acadêmicas.

\section{1}

\section{Explorando alguns conceitos-chave}

Primeiramente, partimos do princípio de que a relação entre indivíduo e sociedade é um movimento duplo, não sendo possível olhar individualmente a cada um dos lados e sim, a partir de sua relação, como destaca Norbert Elias (1989). A relação sociedade/indivíduo é, portanto, interdependente. Por outro lado, a sociedade não pode ser concebida apenas ao se considerar as estruturas institucionais e sociais sobre os indivíduos. Para o autor, “o indivíduo só pode ser entendido em termos de sua vida em comum com os outros" (Elias, 1989, p. 56).

Neste aspecto, Elias mostra que é importante superar a dualidade sujeito/sociedade. Para tanto, o autor sugere uma mudança de olhar copernicana,

quando o indivíduo para de tomar a si mesmo como ponto de partida de seu pensamento, para de fitar o mundo como alguém que olha de "dentro" de sua casa para a rua "lá fora", para as casas "do outro lado", e quando é capaz [...] de ver a si e a sua concha como parte da rua, de vê-los em relação a toda a rede humana móvel, só então é que se desfaz, pouco a pouco, seu sentimento de ser uma coisa isolada e contida "do lado de dentro", enquanto os outros são algo separado dele 
por um abismo, são uma "paisagem", um "ambiente", uma "sociedade" (Elias, 1994, p. 53).

Nesse sentido, o curso de pedagogia foi analisado considerando-o como parte de um processo maior de demanda crescente por cursos universitários, e de um movimento de democratização deste, que carrega consigo processos de desigualdades individuais e sociais de acesso e permanência. Ademais, concordamos com Elias (1987, p. 36) para quem

é impossível compreender com rigor a estrutura de uma sociedade se não souber encará-la simultaneamente em duas perspectivas: a nossa - e falamos dela na terceira pessoa - e na dela - ouvimos os seus membros referirem-se dela na primeira pessoa.

Por isso, construímos um caminho metodológico onde os envolvidos no processo de formação, estudantes e professores, pudessem expor suas percepções sobre as condições de formação oferecidas no curso de pedagogia nos períodos diurno e noturno. Nossa perspectiva de análise buscou olhar para tal realidade social "não só pelas concepções dos seus participantes, mas também por causas estruturais que escapam à sua consciência" (Vandenberghe, 1999, s.p.).

Assumimos a perspectiva bourdiana de que o real é relacional, ou seja, um objeto de estudo precisa ser pensado a partir de todas as relações que ele possibilita. Vandenberghe (1999), analisando esta questão, afirma que para a construção deste

sistema de relações entrelaçadas, duas coisas são importantes: em primeiro lugar, o sistema tem de ser completo, isto é, toda a população de elementos relevantes tem de ser levada em consideração; em segundo, os elementos têm de estar ligados uns aos outros por meio de relações internas, ou seja, de tal modo que não possam ser definidos independentemente uns dos outros, portanto de maneira que estejam mútua e conceitualmente implicados uns nos outros (Vandenberghe, 1999, s.p.).

Ao olhar para a origem social dos estudantes, percebemos, como Bourdieu e Passeron (1975), que há uma estreita ligação desta com as desigualdades escolares dos alunos, as quais tendem a reproduzir as posições de dominação na sociedade. 
Lançamos mão dos conceitos de habitus, capital, campo e estratégia de Bourdieu para pensar o perfil do estudante de pedagogia e seu envolvimento com o curso. O conceito de trajetória do sociólogo francês permite ainda entender as relações anteriores de nosso estudante tanto no que diz respeito à sua origem social, como na trajetória escolar vivenciada por eles. $\mathrm{Na}$ perspectiva relacional, compreendemos com Vandenberghe (1999, s.p.) que "as noções de campo, capital e habitus não podem ser definidas separadamente", mas, sim, na relação entre elas.

Para Bourdieu, "os habitus são princípios geradores de práticas distintas e distintivas (...), mas também são esquemas classificatórios, princípios de classificação, princípios de visão e de divisão e gostos diferentes" (Bourdieu, 2011, p. 22). Este conceito ajuda a explicar, por exemplo, as escolhas dos estudantes de pedagogia pelo curso analisado, e, de modo mais específico, suas escolhas pelo curso superior. Para o autor, "o habitus é essa espécie de senso prático do que se deve fazer em uma dada situação - o que chamamos no esporte de senso do jogo, arte de antecipar o futuro do jogo inscrito, em esboço, no estado atual do jogo" (Bourdieu, 2011, p. 22).

Já a noção de capital em Bourdieu (2012) está relacionada a uma bagagem socialmente herdada pelo indivíduo, com componentes externos a este, o que auxilia na compreensão de aspectos que poderiam contribuir para a promoção do sucesso ou fracasso escolar de nossos estudantes no meio universitário. Numa primeira categoria, encontra-se o capital econômico, entendido como conjunto de "bens e serviços a que ele dá acesso, o capital social, definido como o conjunto de relacionamentos sociais influentes mantidos pela família, além do capital cultural" (Nogueira \& Nogueira, 2002, p. 21), sendo este último considerado como indispensável para se compreender os processos de produção da desigualdade escolar. O capital cultural é reconhecido em três estados, no estado incorporado, no estado objetivado e no estado institucionalizado.

Segundo Bourdieu (2012), o processo de acumulação de capital cultural exige uma incorporação, um trabalho de inculcação e assimilação sob uma pessoa, ou seja, tornando-se "parte integrante da pessoa, um habitus" (Bourdieu, 2012, p. 75), e para isso exige um grande investimento pessoal, em especial, de tempo. Por tal motivo, este tipo de capital está ligado também à influência do capital cultural 
familiar, já que este deve ser transmitido desde a origem da criança, durante todo o seu processo de socialização, ou seja, faz parte das relações estabelecidas com o mundo social dentro do parâmetro do gosto e valores familiares.

O estado objetivado do capital cultural está ligado à apropriação material de bens culturais, como, por exemplo, obras de arte, como quadros e esculturas. Além de o capital econômico ser fundamental ao capital cultural objetivado, há uma forte correlação entre este e o capital cultural em seu estado incorporado, de modo a haver uma apropriação adequada ou específica do capital objetivado. Não basta ter, mas é preciso saber usufruir determinada obra, o que se trata de um processo de apreciação simbólica.

O terceiro estado do capital cultural é o institucionalizado, isto é, aquele que é conferido pela certificação. O capital institucional é um importante conceito para nosso estudo, já que possibilita entender o ingresso ao ensino superior como "magia coletiva" conferida pelo poder do diploma. A conferência de um certificado ao possuidor de determinado capital cultural permite, de acordo com Bourdieu (2012), a comparação entre os diplomados e também fazer o que o autor chama de convertibilidade entre capital cultural e capital econômico.

Tais conceitos são fundamentais ao nosso trabalho na medida em que "a determinado volume de capital herdado corresponde um feixe de trajetórias praticamente equiprováveis que levam a posições praticamente equivalentes trata-se dos campos dos possíveis oferecido objetivamente a determinado agente" (Bourdieu, 2011, p. 99). Nessa perspectiva, olhamos para a escolha do curso estudado por nossos estudantes como correlação direta deste "campo dos possíveis" em que ele se encontra.

Considerando, assim, que o estudante está inserido no campo universitário, com cujas exigências ele age de acordo, ele precisa lidar com o "senso de jogo" deste campo, ou seja, saber agir de acordo com as suas disposições incorporadas e com as regras. Para tanto, ele cria estratégias para a sua manutenção no jogo, que já é bastante desigual frente às exigências das demais carreiras universitárias. Suas condições para estudo normalmente são inferiores às de estudantes de carreiras de prestígio: precisam lidar com baixo capital econômico, social e cultural. Além disso, há diferentes estratégias acionadas pelos estudantes no interior deste campo, 
entre os cursos oferecidos no diurno e noturno, o que nos motivou à investigação sobre as características dos alunos e das práticas institucionais específicas aos dois turnos.

Apoiamo-nos também nos estudos sobre qualidade da educação na perspectiva da eficácia escolar (Bressoux, 2003; Gomes, 2005; Franco et al. 2007; Brooke \& Soares, 2008; Andrade \& Soares, 2008), que atentam especificamente para a contribuição dos fatores extra e intraescolares na promoção da aprendizagem dos estudantes da educação básica. Apesar de tais estudos focarem em nível de ensino diferente daquele por nós estudado, entendemos que suas contribuições podem enriquecer as questões identificadas no ensino superior, em especial, nas diferenciações de condições de formação oportunizadas pelo curso de pedagogia nos diferentes turnos, diurno e noturno, resultado direto da organização dos processos de aprendizagem pela instituição escolar.

A literatura que analisa o denominado "efeito-escola" na promoção da aprendizagem escolar remete à organização escolar uma grande responsabilidade no desempenho final dos estudantes. Para Costa e Koslinski (2005, p. 307), o efeito-escola "conduzem a atenção para o valor e a capacidade da instituição em alterar previsões acerca da trajetória escolar e, presumivelmente, social de sua clientela". A organização curricular, a distribuição de professores, a distribuição dos estudantes pelas turmas, são, portanto, importantes aspectos que influem no sucesso ou fracasso escolar destes estudantes.

Ressalto que não tratamos de desempenho em nosso estudo, ou seja, não analisamos nossas questões relacionando-as às notas obtidas pelos estudantes nas disciplinas acadêmicas, mas buscaremos identificar os processos intrainstitucionais que promoveriam o sucesso ou o fracasso na trajetória acadêmica de nossos estudantes no ensino superior, como sugerem Lopes e Costa (2009), Coulon (2004), Tinto (2004). Relembro que consideramos como percursos e trajetórias de sucesso destes estudantes no curso de pedagogia, a possibilidade de estes estudantes possuírem condições de vivenciar o curso superior aproveitando todas as oportunidades que a universidade lhe oferece, como vimos em Lopes e Costa (2009). Bressoux (2003) enfatiza que as pesquisas acerca do efeito escola se desenvolveram sobre um contexto de análise a respeito da igualdade de oportunidades, de modo que "cada um fosse colocado em condições escolares 
justas" (Bressoux, 2003, p. 44). Nesta perspectiva, consideramos a distribuição de recursos da universidade e a igualdade de oportunidades à experimentação da vida acadêmica por todos os estudantes, sem diferenciação entre turnos, importantes fatores de análise em nossa pesquisa.

Levamos em consideração, portanto, o importante lugar da organização dos processos de aprendizagem pela instituição escolar, ou seja, o efeito escola, ou ainda, o "efeito das diferenças de tratamento das escolas", que, segundo Gomes (2005, p. 283), constituem os denominados "efeitos turma" e "efeito professor". Em nosso caso, vamos considerar tais processos como efeito da instituição escolar, ou, efeito-universidade.

O chamado efeito turma ocorre, conforme Sousa e Silva (2007), quando a instituição escolar organiza as turmas de estudantes por questões de idade, comportamento, ou mesmo turno. Costa e Koslinski (2005, p. 310), a partir de estudos sobre o tema, concluem que "essas práticas levam ao aumento da desigualdade de performance e contribuem para o aumento da desigualdade entre grupos sociais, uma vez que essas divisões de turmas coincidem com características socioeconômicas, de raça e de cor". Este é um importante conceito para se pensar a organização do curso de pedagogia em seus dois turnos, permitindo que analisemos se há diferenciação entre os processos de formação entre os turnos, que possa repercutir positiva ou negativamente no percurso acadêmico de nossos estudantes.

O efeito professor tem por objetivo colocar em evidência as práticas docentes que promovessem as aquisições dos estudantes (Bressoux, 2003). Embora nosso enfoque não seja avaliar as práticas docentes eficazes, o que demandaria outra estratégia de coleta de dados, este conceito possibilita avaliar se os professores relatam alterar suas práticas de sala de aula, de modo a atender às diferenças entre o grupo de alunos. Outro fator para a análise do efeito professor está nos processos de distribuição destes entre as turmas, pois como observado nas pesquisas de Sousa e Silva (2007) e Costa e Koslinski (2005), há seleção dos melhores professores para as melhores turmas. Bressoux, inclusive, propõe a seguinte questão: "a escola é mais eficaz porque ela atrai e emprega professores eficazes, ou a eficácia de um professor é desenvolvida pelas características do ambiente da escola?" (Bressoux, 2003, p. 70). 
Entendemos, deste modo, que para que os estudantes tenham condições favoráveis à sua formação são necessários inúmeros aspectos intra-institucionais. A organização dos processos de aprendizagem e a distribuição de recursos humanos, materiais e culturais pela universidade - considerados pela literatura como efeito-escola - estão ligados à oferta de oportunidades para todos os estudantes. Por fim, outro importante fator a ser apreciado é o planejamento do curso universitário. Bressoux (2003) identifica como elementos positivos para a organização da instituição escolar fatores como a participação de todo corpo docente em todas as decisões da instituição, sobretudo na elaboração da proposta curricular do curso, de modo que haja clareza dos objetivos da proposta, com a intenção de que todos possam a ela se conectar.

Neste sentido, vale pensar nos cuidados que Tardif (2008) julga necessários ao se planejar um curso universitário mais voltado aos interesses e necessidades dos estudantes do que às exigências da universidade. Segundo ele,

o ensino deve estar à disposição do aprendizado dos estudantes. Nós cremos, por conseguinte, que um programa de qualidade deve estar centrado de preferência nos estudantes e em seu aprendizado, e não em critérios administrativos (os horários, a repartição dos cursos entre as disciplinas etc.) ou nos interesses e nas crenças de formadores (por exemplo, na importância de sua disciplina, na defesa de seu território, de sua autoridade etc.). O objetivo de um programa não é de satisfazer os formadores na repartição dos cursos, mas sim de fazer que os alunos aprendam os elementos essenciais de sua futura prática profissional (Tardif, 2008: 10).

De acordo com Costa e Lopes (2009), baseados em Madureira Pinto, uma análise sobre ensino superior como um trabalho coletivo obriga-nos a considerar $\mathrm{o}(\mathrm{s})$ modelo(s) organizacionais, que muitas vezes relutam em pensar sobre a “problemática pedagógica, já que o 'serviço' que mais marca o dia-a-dia dos estabelecimentos e dos seus profissionais diz respeito, como é sabido, as atividades de ensino" (Costa \& Lopes, 2009, p. 33). A "problemática pedagógica" a que se refere os autores é concernente ao exercício de pensar os processos de aprendizagem de estudantes universitários, que chegam à universidade cada vez mais heterogêneos socialmente. $\mathrm{Na}$ avaliação destes pesquisadores, esta é uma 
característica que tem de ser tomada em conta sempre que esteja em causa pensar e reformar planos curriculares, conteúdos e métodos pedagógicos, com vista, nomeadamente, a uma promoção efetiva do sucesso escolar e a um combate consequente ao abandono e insucesso neste nível de ensino. (Costa \& Lopes, 2009 , p. 33)

\section{2}

\section{Estratégias de investigação/método}

A escolha da Universidade do Estado do Rio de Janeiro (UERJ), campus Maracanã, se deu, primeiramente, por esta ser uma das principais universidades públicas do Rio de Janeiro, e, especialmente, por apresentar características peculiares no curso de pedagogia. Nesta instituição, o curso de pedagogia conta com cerca de 1500 alunos matriculados. Anualmente, são selecionados 360 estudantes para ingressarem no curso. Além disso, sua localização, acessível através de diferentes meios de transporte público, como trem, metrô e diversas linhas de ônibus destinadas a todo o grande Rio e Baixada Fluminense, nos faz supor que se trata de uma universidade que atenda a diferentes regiões da cidade e mesmo do estado do Rio de Janeiro.

A UERJ foi escolhida por focalizar dentro da pesquisa do SOCED, uma universidade do estado, com enfoque sobre os perfis de estudantes de seu curso nos períodos diurno e noturno. Além disso, a universidade, especialmente a faculdade de educação, demonstrou muita abertura à realização de nosso estudo, nos auxiliando na aplicação dos questionários e possibilitando os contatos com os professores do curso.

De modo a contemplar nosso objetivo de estudo, buscamos informações sobre as condições de formação e de estudo dos estudantes do curso de pedagogia dos períodos diurno e noturno junto aos próprios estudantes e aos professores. Para a produção do material empírico da pesquisa, recorremos a entrevistas com os professores do curso, aplicação de questionários aos estudantes, conversas informais com estudantes do curso ao longo das inúmeras visitas realizadas à 
instituição, bem como análise de relatos dos estudantes sobre suas experiências no curso.

Em um primeiro momento, visitei a instituição em diferentes dias e horários da semana. Durante estas visitas, pude realizar observações da dinâmica do espaço e seus sujeitos. Normalmente, eu me sentava no hall que dá acesso às salas de aula e, sempre com meu caderno de campo em mãos, fazia algumas observações. Por vezes, conversava com alguns estudantes. Nestas ocasiões, eu me apresentava, falava sobre meu estudo e os pedia que comentassem sobre sua experiência do curso, caso se sentissem à vontade para fazê-lo. Esses encontros não foram gravados, mas eu solicitava autorização aos estudantes para realizar anotações. Em uma dessas conversas, o estudante, que realizava iniciação científica, disse que se eu quisesse, poderia gravar nossa conversa, o que fiz. Nessas conversas informais, 15 ao todo, sempre obtive bom retorno, pois todos estavam muito dispostos a comentar a experiência no curso. Por vezes, acompanhei alguns eventos que ocorriam pela universidade, como palestras e a semana de educação realizada pela Faculdade de Educação. Estes momentos possibilitaram a observação de como os estudantes se comportam e agem (ou não) nos espaços e atividades oferecidas pela universidade.

\subsection{1}

\section{Entrevistas}

Concomitantemente a estas observações, foram realizadas entrevistas com a diretora da faculdade de educação, com a vice-diretora e com dois professores que fizeram/fazem parte da coordenação do curso estudado, com o objetivo de obter informações sobre o que se considerariam as principais questões que permeiam a concepção do curso, sua proposta curricular e condições de formação oferecida aos estudantes na concepção da gestão do curso. A escolha dos três últimos coordenadores e atual direção deve-se ao fato de recentemente ter havido troca da direção, e, portanto, o olhar de pessoas em momentos diferentes do curso pôde 
nos ajudar a compreender as mudanças sofridas pelo curso de pedagogia a fim de melhorar a formação oferecida ao corpo discente.

Outras 11 entrevistas foram realizadas com docentes efetivos e uma com um professor substituto, dos diferentes departamentos da Faculdade de Educação. Foram contatados professores que possuem maior tempo na instituição, que puderam acompanhar as principais mudanças enfrentadas pelo curso, mas também professores mais recentes. Foi possível, ainda, no decorrer das visitas à UERJ, conversar com alguns outros professores substitutos, que compõem cerca de $50 \%$ do quadro docente da faculdade. Nossas conversas em geral foram em torno das condições de trabalho na instituição. Ao todo, foram entrevistados 16 professores da instituição (quatro gestores, 11 professores efetivos e um professor substituto).

O perfil dos nossos entrevistados é de maioria feminina, 10 mulheres e seis homens. Todos já tiveram alguma experiência no ensino noturno e atualmente metade deles leciona aos estudantes do curso noturno. A diretora e a vice-diretora, por exemplo, se revezam nas atividades da gestão e, portanto, uma mantém-se na universidade nos períodos da manhã/tarde, enquanto que a outra nos períodos tarde/noite. Entre os oito professores que atuam somente pela manhã, cinco fazem parte do programa de pós-graduação da instituição. Somente a coordenadora do curso dá aula para os estudantes do curso noturno e também atua na pósgraduação, apesar de, recentemente, ter diminuído suas atividades nesta última para se dedicar ao curso de pedagogia.

$\mathrm{Na}$ terceira etapa foi aplicado um survey a uma amostra de estudantes de períodos finais do curso. A opção pela amostra de estudantes considerou o grande número de alunos do curso, cerca de 1500, como já mencionado.

\subsection{2}

\section{O questionário}

Em disciplina de trabalho supervisionado de pesquisa, oferecida na turma de doutorado em ciências humanas/educação, a professora Zaia Brandão propôs aos 
estudantes trabalharem diferentes encaminhamentos metodológicos de pesquisa, através de duas etapas, uma teórica e outra prática. Assim, após uma discussão teórica sobre diferentes tópicos de assuntos ligados à pesquisa, como observação, entrevista, questionário, entre outros, os estudantes de doutorado realizavam exercícios práticos de acordo com cada assunto. No momento da discussão sobre pesquisa quantitativa, a professora Zaia comentou sobre sua atual pesquisa que visa à realização de estudos de caso sobre o curso de pedagogia em diferentes instituições. Surgiu daí a ideia de realizar em conjunto um primeiro esboço de um questionário a ser aplicado aos estudantes do curso de pedagogia na UERJ.

A construção inicial dos questionários foi realizada a partir de eixos conceituais, já trabalhados pelo SOCED em pesquisas anteriores, sobre processos de produção de qualidade de ensino, e discutidos pela professora Zaia com os estudantes do curso de doutorado. São eles, a trajetória escolar do aluno e o contexto escolar, em nosso caso, do curso de pedagogia; práticas de estudo do aluno; questões sociodemográficas e capital cultural. Em cada grupo conceitual os estudantes elaboraram inúmeras questões para o questionário, a partir de levantamento de diversos modelos de questionários existentes da área, como os do ENADE, do ENEM, modelos utilizados pelos grupos de pesquisa dos estudantes, entre outros. Cada bloco foi discutido nas aulas, sendo realizadas modificações pelos próprios colegas e professora.

Em uma segunda etapa da elaboração dos questionários, este esboço inicial foi levado para a discussão da equipe do SOCED, ocasião em que trabalhamos sobre cada questão intensamente a partir do trabalho realizado por cada membro do grupo, primeiro individualmente, e depois discutidas por todo o grupo. Neste processo, algumas questões foram retiradas, outras inseridas e muitas reelaboradas, e um segundo esboço do questionário foi produzido.

Esse instrumento foi testado com 56 estudantes de duas universidades, uma federal e outra particular. Durante este pré-teste, foi solicitado aos estudantes que dessem sugestões sobre as questões e fizessem as anotações que julgassem interessantes para melhorar o instrumento. Reunimos as sugestões dos estudantes, analisamos as respostas e as discutimos novamente no grupo de pesquisa, fazendo novas modificações ao instrumento de modo a torná-lo mais claro e eficiente. Contamos ainda com a consultoria de uma especialista em dados quantitativos 
para verificar se o instrumento estava adequado à produção de um banco de dados, solicitando também suporte na organização das questões, bem como na formatação final do instrumento. Por fim, solicitamos uma avaliação de uma especialista da área de educação, que atestou que o questionário estava adequado aos objetivos da pesquisa.

Segue abaixo o quadro-resumo dos conceitos do questionário (em anexo) aplicado aos estudantes.

\section{Quadro 1 - Quadro-resumo dos conceitos dos itens do questionário dos estudantes}

\begin{tabular}{|c|c|c|c|c|}
\hline Tema & Conceito & $\begin{array}{c}\text { Classificação } \\
\text { do conceito }\end{array}$ & Especificação & $\begin{array}{l}\text { Operacionalizaçã } \\
\text { o como item do } \\
\text { questionário }\end{array}$ \\
\hline \multirow{9}{*}{ 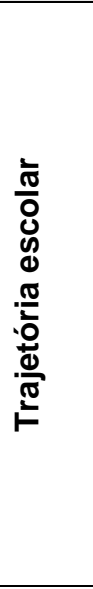 } & \multirow{3}{*}{$\begin{array}{l}\text { Trajetória } \\
\text { escolar na } \\
\text { educação } \\
\text { básica }\end{array}$} & Observável & $\begin{array}{l}\text { Tipo de instituição onde } \\
\text { estudou }\end{array}$ & Bloco $1 \mathrm{P} 1$ \\
\hline & & Observável & $\begin{array}{l}\text { Tipo de ensino médio } \\
\text { concluído }\end{array}$ & Bloco $1 \mathrm{P} 2$ \\
\hline & & Observável & $\begin{array}{l}\text { Turno de estudo no ensino } \\
\text { médio }\end{array}$ & Bloco 1 P3 \\
\hline & \multirow{6}{*}{$\begin{array}{ll}\text { Trajetória } & \\
\text { escolar } & \text { no } \\
\text { curso } & \text { de } \\
\text { pedagogia } & \end{array}$} & Observável & $\begin{array}{l}\text { Ano e semestre de ingresso } \\
\text { no curso de pedagogia }\end{array}$ & Bloco 1 P4 \\
\hline & & Observável & $\begin{array}{l}\text { Turno em que cursa } \\
\text { pedagogia }\end{array}$ & Bloco 1 P5 \\
\hline & & Latente & Motivo de escolha do curso & Bloco $1 \mathrm{P} 6$ \\
\hline & & Observável & $\begin{array}{l}\text { Pedagogia como primeira } \\
\text { opção }\end{array}$ & Bloco 1 P7, P8 \\
\hline & & Observável & Área de interesse profissional & Bloco 1 P9 \\
\hline & & Observável & É cotista? & Bloco $1 \mathrm{P} 10$ \\
\hline \multirow{10}{*}{ 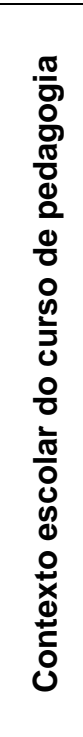 } & \multirow{8}{*}{$\begin{array}{l}\text { Avaliação do } \\
\text { curso }\end{array}$} & Observável & Mudaria de curso? & $\begin{array}{l}\text { Bloco } 2 \text { P11 e } \\
\text { P12 }\end{array}$ \\
\hline & & Latente & Avaliação das disciplinas & Bloco 2 P13 \\
\hline & & Latente & $\begin{array}{l}\text { Avaliação do domínio do } \\
\text { conteúdo pelo professor }\end{array}$ & Bloco 2 P14 \\
\hline & & Observável & Tipos de avaliação & Bloco 2 P15 \\
\hline & & Observável & Usos de matérias didáticos & Bloco 2 P16 \\
\hline & & Latente & $\begin{array}{l}\text { Avaliação do nível } \\
\text { exigência do curso }\end{array}$ & Bloco 2 P18 \\
\hline & & Latente & $\begin{array}{l}\text { Habilidades e competências } \\
\text { desenvolvidas }\end{array}$ & Bloco 2 P19 \\
\hline & & Latente & Satisfação com o curso & Bloco 2 P21 \\
\hline & $\begin{array}{l}\text { Participação } \\
\text { em atividades }\end{array}$ & Observável & $\begin{array}{l}\text { Participação em outras } \\
\text { atividades acadêmicas e } \\
\text { demais oferecidas pela } \\
\text { universidade }\end{array}$ & Bloco 2 P17 \\
\hline & $\begin{array}{l}\text { Problemas na } \\
\text { formação }\end{array}$ & Observável & $\begin{array}{l}\text { Possíveis } \\
\text { encontradas } \\
\text { formação. }\end{array}$ & Bloco 2 P20 \\
\hline
\end{tabular}




\begin{tabular}{|c|c|c|c|c|}
\hline Tema & Conceito & $\begin{array}{l}\text { Classificação } \\
\text { do conceito }\end{array}$ & Especificação & $\begin{array}{l}\text { Operacionalização } \\
\text { como item do } \\
\text { questionário }\end{array}$ \\
\hline \multirow{5}{*}{ 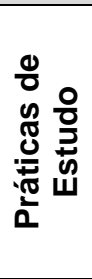 } & \multirow{5}{*}{$\begin{array}{l}\text { Práticas de } \\
\text { estudo }\end{array}$} & Latente & Hábito de estudo & Bloco 3 P22 \\
\hline & & Observável & Ambiente de estudo & Bloco 3 P23 \\
\hline & & Observável & $\begin{array}{l}\text { Tempo semanal dedicado } \\
\text { ao estudo }\end{array}$ & Bloco 3 P24 \\
\hline & & Observável & Pesquisa & $\begin{array}{llll}\text { Bloco } & 3 & \text { P25 } & \text { e } \\
\text { P26 } & & & \\
\end{array}$ \\
\hline & & Latente & Dificuldades acadêmicas & Bloco 3 P27 \\
\hline \multirow{8}{*}{$\begin{array}{l}\bar{\pi} \\
\frac{\pi}{3} \\
\frac{7}{3} \\
0 \\
\frac{0}{0} \\
0 \\
\frac{0}{0} \\
\frac{\pi}{0} \\
\frac{0}{0} \\
0\end{array}$} & Atitude de leitura & Latente & Práticas de leitura & Bloco 4 P28 \\
\hline & \multirow[t]{2}{*}{$\begin{array}{l}\text { Práticas de } \\
\text { leitura }\end{array}$} & Observável & $\begin{array}{l}\text { Livros lidos recentemente / } \\
\text { indicação }\end{array}$ & $\begin{array}{llll}\text { Bloco } & 4 & \text { P29 } & \text { e } \\
\text { P30 } & & & \\
\end{array}$ \\
\hline & & Observável & $\begin{array}{l}\text { Livros comprados para } 0 \\
\text { curso }\end{array}$ & $\begin{array}{llll}\text { Bloco } & 4 & \text { P30 } & \text { e } \\
\text { P31 } & & & \\
\end{array}$ \\
\hline & \multirow[t]{2}{*}{ Práticas de lazer } & Observável & $\begin{array}{l}\text { Tipos de programas } \\
\text { televisivos mais assistidos }\end{array}$ & Bloco 4 P32 \\
\hline & & Observável & $\begin{array}{l}\text { Participação em eventos } \\
\text { culturais }\end{array}$ & Bloco 4 P34 \\
\hline & Práticas sociais & Observável & $\begin{array}{l}\text { Participação em atividades } \\
\text { sociais }\end{array}$ & Bloco 4 P33 \\
\hline & \multirow[t]{2}{*}{ Práticas culturais } & Observável & $\begin{array}{l}\text { Conhecimento da língua } \\
\text { inglesa }\end{array}$ & Bloco 4 P36 \\
\hline & & Observável & $\begin{array}{l}\text { Realização de viagem ao } \\
\text { exterior }\end{array}$ & Bloco 4 P35 \\
\hline \multirow{5}{*}{ 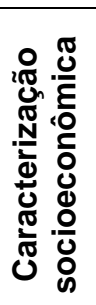 } & \multirow{3}{*}{$\begin{array}{lr}\text { Grau } & \text { de } \\
\text { instrução } & \text { dos } \\
\text { pais } & \end{array}$} & lável & Escolaridade do pai & Bloco 5 P37 \\
\hline & & Observável & Escolaridade da mãe & Bloco 5 P38 \\
\hline & & Observável & $\begin{array}{ll}\text { Escolaridade } & \text { do } \\
\text { mantenedor da família } & \end{array}$ & Bloco 5 P41 \\
\hline & \multirow[t]{2}{*}{ Posse de bens } & Observável & Indicadores econômicos & $\begin{array}{l}\text { Bloco } 5 \\
\mathrm{P} 42, \mathrm{P} 40\end{array}$ \\
\hline & & Observável & Posse de bens & Bloco 5 P53 \\
\hline \multirow{3}{*}{ 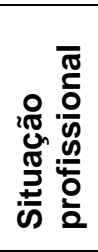 } & Trabalho & Observável & Faz estágio ou trabalha? & $\begin{array}{llll}\text { Bloco } & 5 & \text { P54 } & \text { e } \\
\text { P55 } & & & \\
\end{array}$ \\
\hline & Atuação & Observável & $\begin{array}{l}\text { Área da } \\
\text { profissional }\end{array}$ & Bloco 5 P56 \\
\hline & $\begin{array}{l}\text { Período } \\
\text { trabalho }\end{array}$ & Observável & Regime de trabalho & Bloco 5 P57 \\
\hline \multirow{8}{*}{ 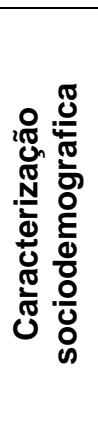 } & Estrutura familiar & Observável & $\begin{array}{l}\text { Pessoas residentes com o } \\
\text { estudante }\end{array}$ & $\begin{array}{llll}\text { Bloco } & 5 & \text { P47 } & \text { e } \\
\text { P48 } & & & \\
\end{array}$ \\
\hline & Sexo & Observável & Sexo & Bloco 5 P450 \\
\hline & Cor & Observável & Cor declarada & Bloco 5 P51 \\
\hline & Estado & Observável & Estado civil & Bloco 5 P44 \\
\hline & Filhos & Observável & Número de filhos & $\begin{array}{lllll}\text { Bloco } & 5 & \text { P45 } & \text { e } \\
\text { P45.1 } & & & \\
\end{array}$ \\
\hline & Idade & Observável & Data de nas & Bloco 5 P49 \\
\hline & Endereço & Observável & CEP & Bloco 5 P52 \\
\hline & $\begin{array}{l}\text { Deslocamento } \\
\text { diário }\end{array}$ & Observável & $\begin{array}{l}\text { Tempo diário gasto em } \\
\text { deslocamento }\end{array}$ & Bloco 5 P46 \\
\hline
\end{tabular}

Fonte: Questionário SOCED / Pesquisa: Cursos de pedagogia - estudos de caso e desafios à produção de qualidade do ensino fundamental. 


\subsection{3}

\section{A aplicação dos questionários}

Com o instrumento elaborado, organizamos a aplicação dos questionários, inicialmente na Faculdade de Educação da UERJ Maracanã, campo empírico desta pesquisa. A aplicação foi organizada em parceria com a coordenação do curso de pedagogia, que buscou selecionar as disciplinas de acordo com a possibilidade dos professores em disponibilizar parte de suas aulas para a realização da pesquisa. A coordenação cuidou também de avisá-los e colocá-los em contato conosco.

Aplicamos os questionários em 16 turmas do curso de pedagogia da UERJ, oito do turno da manhã e oito do turno da noite, contemplando os $5^{\circ}, 6^{\circ}, 7^{\circ}$ e $8^{\circ}$ períodos dos dois turnos. A opção por aplicar os questionários a partir do $5^{\circ}$ período relacionava-se com o interesse de que o aluno já possuísse uma boa vivência do curso de pedagogia, podendo, assim, responder às questões que oferecessem subsídios para a análise do processo de formação prévia desses estudantes no curso e das condições do aluno para se dedicar aos estudos.

O quadro 2 retrata o número de alunos matriculados nas disciplinas em que aplicamos os questionários, por período, identificando também o número de respondentes em cada turma. Como se pode observar pelo quadro (2) de inscritos nas disciplinas, percebemos que as turmas do curso noturno são maiores, especialmente no final do curso. Normalmente, muitos estudantes cuja matrícula originalmente é do curso diurno tentam vaga nas turmas do noturno ao conseguirem algum estágio ou trabalho no decorrer dos anos de estudo. Por tal razão, obtivemos um maior número de respondentes neste turno. Ao questionar os professores sobre certo esvaziamento de algumas turmas, eles informaram que é normal, pois há sempre um grupo de alunos que falta às aulas. Na turma com menor índice de respondentes, 34,7\%, do oitavo período da manhã, alguns estudantes informaram que a maioria só vai à UERJ para assistir àquela disciplina, e, por tal razão, a turma é sempre esvaziada, principalmente porque o professor não realiza a chamada. 
Quadro 2 - Alunos matriculados nas disciplinas em que foram aplicados os questionários $\mathrm{x}$ respondentes

\begin{tabular}{|c|c|c|c|c|c|c|c|c|c|}
\hline \multicolumn{10}{|c|}{ Alunos matriculados nas disciplinas $\mathrm{X}$ respondentes } \\
\hline \multicolumn{5}{|c|}{ Manhã } & \multicolumn{5}{|c|}{ Noite } \\
\hline $\begin{array}{l}\frac{}{0} \\
\text { 음 } \\
0\end{array}$ & 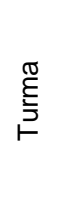 & 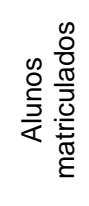 & 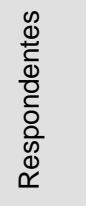 & 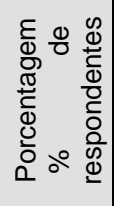 & $\begin{array}{l}\text { 응 } \\
\frac{0}{\overline{0}} \\
0\end{array}$ & $\stackrel{\stackrel{g}{\xi}}{\stackrel{g}{F}}$ & 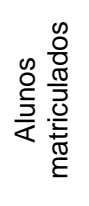 & 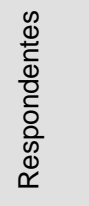 & 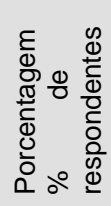 \\
\hline \multirow[t]{2}{*}{$5^{\circ}$} & 01 & 25 & 19 & 76 & \multirow[t]{2}{*}{$5^{\circ}$} & 03 & 39 & 20 & 51,2 \\
\hline & 02 & 31 & 23 & 74,1 & & 04 & 32 & 22 & 68,7 \\
\hline \multirow[t]{2}{*}{$6^{\mathrm{O}}$} & 01 & 37 & 26 & 70,2 & \multirow[t]{2}{*}{$6^{\mathrm{O}}$} & 03 & 39 & 26 & 66,6 \\
\hline & 02 & 35 & 24 & 68,5 & & 04 & 32 & 25 & 78,1 \\
\hline \multirow[t]{2}{*}{$7^{\circ}$} & 01 & 17 & 12 & 70,5 & \multirow[t]{2}{*}{$7^{\mathrm{O}}$} & 03 & 23 & 19 & 82,6 \\
\hline & 02 & 14 & 11 & 78,5 & & 04 & 37 & 23 & 62,1 \\
\hline \multirow[t]{2}{*}{$8^{\circ}$} & 01 & 23 & 08 & 34,7 & \multirow[t]{2}{*}{$8^{\circ}$} & 03 & 44 & 27 & 61,3 \\
\hline & 02 & 28 & 18 & 64,2 & & 04 & 40 & 29 & 72,5 \\
\hline \multicolumn{2}{|c|}{ TOTAL } & 210 & 141 & 67,1 & \multicolumn{2}{|c|}{ TOTAL } & 286 & 191 & 66,8 \\
\hline
\end{tabular}

Fonte: Questionário SOCED / Pesquisa: Cursos de pedagogia - estudos de caso e desafios à produção de qualidade do ensino fundamental.

Dentre os estudantes matriculados nas disciplinas em que foram aplicados os questionários, obtivemos ao todo $66,8 \%$ de respondentes do curso noturno e $67,1 \%$ do curso diurno. A maioria dos respondentes do noturno se encontra na etapa final do curso, entre os sétimo e oitavo períodos. Entre os do curso diurno, $63 \%$, se encontram nos quinto e sexto períodos. O que também indica que os dois últimos períodos do curso são mais numerosos à noite. Interessante notar que os poucos alunos $(6,2 \%$,$) que se acham fora do tempo correto do curso, ou seja,$ ingressaram antes de 2010, estão no curso noturno. Esse dado, não pode ser olhado como forte indicativo da pouca representatividade do atraso dos alunos, pois precisaria ser conjugado com o número de alunos que já concluíram todas as disciplinas do curso e que estão retidos pela monografia, prática bastante comum na UERJ. 
Entre os respondentes, obtivemos 332 respostas válidas. Desses, a maioria, $60 \%$, se encontra no curso noturno, como observa-se no gráfico 1.

\section{Gráfico 1 - Percentual de respondentes por turno}

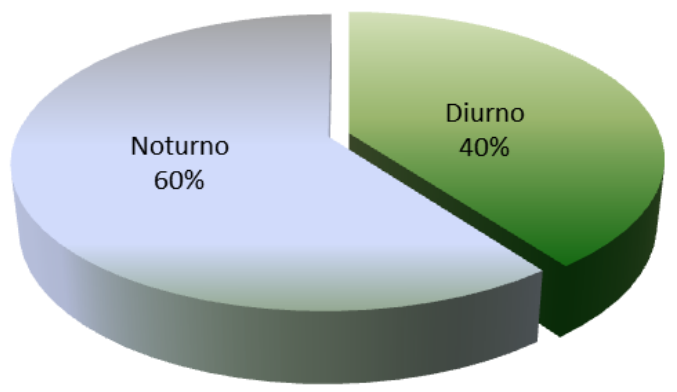

Fonte: Questionário SOCED / Pesquisa: Cursos de pedagogia - estudos de caso e desafios à produção de qualidade do ensino fundamental.

Para organização do banco de dados, agrupamos estudantes que responderam que estudam na parte da tarde e noite como alunos do noturno, já que à tarde são oferecidas apenas disciplinas eletivas. De modo semelhante, agrupamos aqueles que estudam manhã e tarde como alunos do turno diurno. Retiramos de nosso banco de dados oito alunos que mencionaram estudar o dia inteiro, e ainda outros 45 estudantes que cursam disciplinas tanto no diurno como no noturno. Essa opção se deve pelo motivo de querermos identificar diferenças de condições para estudo destes dois grupos. Assim, nossa amostra representa aqueles alunos que estão atualmente matriculados no diurno e noturno.

Como assinalamos, muitos estudantes eram originários de um turno e atualmente se encontram em outro. Escolhemos assim outras estratégias para produção do material empírico de modo a ter condições de interpretar melhor os processos de formação no curso de pedagogia, através do acompanhamento das microssituações sociais (Collins, 2008).

Ressaltamos também que nossos dados estatísticos foram utilizados de modo a levantar questões mais gerais sobre nossos estudantes e suas condições de estudo. Suscitadas estas questões, fomos explorando-as a partir das informações coletadas dos dados qualitativos. 


\section{2 .4}

\section{Relatos dos estudantes}

Durante a aplicação do questionário, composto por questões fechadas, os alunos comentavam que teriam muitas coisas para falar sobre o curso. Alguns até realizaram uma ou outra observação ao final do questionário, que por mim foram anotadas e consideradas nas análises. Tal atitude de abertura por parte dos estudantes nos levou a solicitar algum contato (e-mail ou telefone) dos respondentes para que futuros contatos de pesquisa fossem realizados. Deixamos claro que a disponibilização deste dado era opcional, e, ao final, obtivemos 223 endereços de e-mail dos 334 estudantes que responderam ao nosso questionário.

Decidimos, numa última etapa do trabalho de campo, solicitar aos estudantes, que comentassem por escrito dois aspectos de sua trajetória no curso de pedagogia. Primeiro, como ele chegou ao curso, e, segundo, como está sendo sua experiência de aluno. Montamos uma pequena base em plataforma da internet dedicada a este tipo de trabalho, utilizando a ferramenta do Google drive, explicando aos estudantes que suas respostas seriam anônimas, assim como foi no questionário. Colocamos um campo para o aluno dizer em qual período ele se encontrava, em qual turno ele estudava e qual era seu turno de origem. Após três solicitações, obtivemos um total de 57 respondentes, cerca de $20 \%$ de todos os que nos forneceram seus contatos. Nossas análises buscam cruzar esses olhares sobre o curso.

Cabe ressaltar que nas análises que se seguem usei letras para representar os três tipos de material empírico por nós trabalhados. São eles: "P" para representar o professor entrevistado seguido pelo número de referência; " $R$ " para indicar que o respondente nos enviou um relato, também seguido pelo número do relato, período e turno; e por fim "E" para indicar as entrevistas informais por nós realizadas durante o trabalho de campo. 


\section{Perfil de estudantes e condições sociais de estudo}

Neste capítulo, apresentamos o perfil dos estudantes de pedagogia da UERJ, com o intuito de formular comparações entre estudantes dos turnos diurno e noturno. Analisa-se as condições sociais de estudo dos alunos a partir de suas condições materiais e humanas para se dedicarem às atividades acadêmicas. Apreciamos ainda, as oportunidades acadêmicas disponíveis ao público discente, de modo a avaliar se a universidade em questão propicia um clima acadêmico favorável aos estudos no nível superior.

\section{1}

\section{Perfil dos estudantes de pedagogia da UERJ}

Como já esperado, 90,4\% dos estudantes de pedagogia da instituição estudada é do sexo feminino. Observamos que no curso noturno, há uma presença maior de homens, $13 \%$, contra os 2,5\% do curso diurno. Alguns professores entrevistados destacaram esse fato, informando que muitos desses estudantes são militares e buscam o ensino superior para progredirem na carreira. Há também a presença de líderes religiosos que procuram o curso como aperfeiçoamento profissional.

Nossos estudantes se apresentam, em grande maioria, como jovens, dentro do fluxo contínuo dos estudos, conforme tabela 1. Os dados gerais indicam que 65,6\% dos estudantes de nosso estudo se encontram na faixa etária de jovens entre 18 e 24 anos, 54,1\% entre os que estudam à noite e $81,9 \%$, pela manhã. Tal faixa etária é considerada como adequada pela comunidade científica para a formação em nível superior, já que segue o fluxo normal da formação escolar. Percebemos 
que os estudantes do curso noturno são um pouco mais velhos que os estudantes da manhã, em especial nas faixas etárias acima dos 30 anos, com cerca de 26,7\%.

Tabela 1 - Faixa etária dos estudantes

\begin{tabular}{ccccccc}
\hline & & \multicolumn{4}{c}{ Faixa etária } & \multirow{2}{*}{ Total } \\
\cline { 3 - 6 } & & 18 a 24 anos & 25 a 29 anos & 30 a 39 anos & $\begin{array}{c}\text { Acima de 40 } \\
\text { anos }\end{array}$ & \\
\hline \multirow{2}{*}{ Diurno } & $\mathrm{n}$ & 86 & 11 & 0 & 8 & 105 \\
& $\%$ & $81.9 \%$ & $10.5 \%$ & $0.0 \%$ & $7.6 \%$ & $100.0 \%$ \\
\multirow{3}{*}{ Noturno } & $\mathrm{n}$ & 85 & 30 & 22 & 20 & 157 \\
& $\%$ & $54.1 \%$ & $19.1 \%$ & $14.0 \%$ & $12.7 \%$ & $100.0 \%$ \\
\multirow{3}{*}{ Total } & $\mathrm{n}$ & 171 & 41 & 22 & 28 & 262 \\
& $\%$ & $65.3 \%$ & $15.6 \%$ & $8.4 \%$ & $10.7 \%$ & $100.0 \%$ \\
\hline
\end{tabular}

Fonte: Questionário SOCED / Pesquisa: Cursos de pedagogia - estudos de caso e desafios à produção de qualidade do ensino fundamental.

Esses dados corroboram a afirmação dos professores entrevistados de que os estudantes do noturno são mais maduros que aqueles que estudam pela manhã, que geralmente são recém-saídos do ensino médio e demonstram menos interesse pelo curso. Na fala de um dos professores entrevistados: "De manhã eu me sinto, assim, no jardim de infância. Eles têm muita energia" [P6]. Os professores ressaltam que estes estudantes trazem o que os docentes avaliam como "vícios" da escola básica, com a ideia de que se está ali com a intenção de cumprir tarefas e ser "conduzido pela demanda. Eu tenho que estudar, eu tenho que fazer o trabalho que o professor pede, eu tenho que fazer uma avaliação, eu tenho que cumprir uma demanda" [P13]. Assim, surge a necessidade de esses professores auxiliar seus alunos na aprendizagem da vida universitária, assumindo as responsabilidades individuais para com a formação, o que Coulon (2008) define como aprender a se tornar estudante, condição que envolve "trabalhar em casa, aprofundar, compreender sozinho" (Coulon 2008, p.142). Para os estudantes do curso noturno, a sua experiência de vida os tornou mais maduros, o que os auxilia a ter o que os professores chamam de compromisso com o ensino superior desde o início. " $\mathrm{O}$ perfil dos adultos que estão fora do ano de escolaridade é de maior compromisso com os estudos" [P 13]. 
Com relação ao estado civil de nossos estudantes, $20,3 \%$ dos que estudam no noturno são casados e 21,4\% possuem filhos, já entre os alunos do diurno, são 11,7\% e $9,9 \%$ respectivamente. Com relação à cor, $56,6 \%$ estudantes do noturno se declararam pretos ou pardos, entre os que estudam no diurno, o percentual é de $44,1 \%$.

Apenas 14,8\% dos estudantes ingressaram na UERJ por cotas, $18,3 \%$ entre os estudantes do diurno e 13,7\% entre os do noturno. A principal razão para este número ser relativamente pequeno se deve ao fato de que o perfil dos estudantes de pedagogia, segundo seus professores, sempre foi semelhante ao de alunos cotistas. A política de cotas tem o objetivo de oferecer oportunidades na competição por vagas nos cursos em que os estudantes de estratos de maior nível social, e, portanto, com maior capital escolar, geralmente ocupam. Assim, estudantes com baixo capital escolar, teriam alguma vantagem nesta competição. O curso de pedagogia da UERJ sempre recebeu, segundo os docentes, estudantes oriundos das camadas populares da sociedade, e que, por conseguinte, o ingresso por cotas não modificou o perfil de estudantes do curso: "Não vi nenhuma mudança do perfil. A grande maioria do aluno sempre foi pobre e de pessoas negras. Pessoas que não tem muitas oportunidades. [Como é o caso] em todas as licenciaturas" [P12].

Outro professor que há anos trabalha com alunos do curso diurno, ressalta que houve uma mudança de perfil devido à entrada dos alunos que não são cotistas, ou seja, alunos que entram no curso normalmente através de reclassificações, e não como primeira opção. Para ele, estes alunos geralmente possuem interesses diversos dentro do curso de pedagogia, não procuram o magistério e sim uma forma de entrar na universidade.

Nós imaginávamos que com as cotas teríamos um tipo de aluno que por ter de trabalhar, largasse o curso com maior evidência. Pra nós não, pelo contrário a gente era melhor quando eles eram não-cotistas, porque os nossos alunos na pedagogia eram primariamente os atuais cotistas. Então, quando a gente passou a ter o sistema de cotas, os outros 50\% que não eram cotistas é que eram os estranhos. E esses são os que dão trabalho no início, porque eles querem trabalhar com pedagogia empresarial, querem arrumar um emprego para ganhar muito bem, não querem trabalhar com magistério, entendeu? Até a gente "criá-los", demora um pouquinho. [P14] 
Com relação à moradia desses estudantes, confirmamos que o alunato do curso noturno tende a morar mais próximo da universidade, como se verifica no mapa $1^{3}$. Dias et al. também perceberam esta situação em seus estudos. Para aqueles que se dividem entre trabalho e estudo, realizando sua formação de nível superior no ensino noturno, há a necessidade de se optar por uma instituição que possibilite a conciliação de suas atividades. É bastante positivo o fato de a UERJ ter uma linha de metrô que vai da Zona Norte à Zona Sul, passando pelo Centro do Rio, o que agiliza o tempo de translado diário. Além disso, as variadas linhas de ônibus no entorno da universidade, bem como a linha de trem, também contribuem para o deslocamento diário de nosso alunado.

No mapa 1, a concentração dos estudantes do curso noturno em torno de uma região é clarividente, enquanto que os estudantes do diurno são mais dispersos, apesar de se verificar que estão próximos à linha do trem. Concluímos que os estudantes do noturno são beneficiados pela linha 2 do metrô da cidade, que, passando pela estação Maracanã, próxima à universidade estudada, segue até a Pavuna, favorecendo todos que moram na região e em toda a Baixada Fluminense, através das conexões com linhas de ônibus.

Boa parte dos estudantes mora e trabalha nas imediações da UERJ, conforme dados sobre o tempo de translado diário que os respondentes declararam percorrer. Entre os alunos dos dois turnos, como se verifica nos dados a seguir, não há grande variação com relação ao tempo gasto com transporte em geral, o que engloba o deslocamento de casa, do trabalho, da universidade etc.. Aproximadamente um terço dos estudantes afirma realizar seus trajetos diários em até $1 \mathrm{~h} 30$. Outros $30 \%$ o fazem em até 2 h30. Entre aqueles que passam de 2 h30 a 3 h30 no trânsito, há uma parcela de $21,2 \%$ entre quem estuda pela manhã e de $16,6 \%$ entre quem estuda à noite. Um total de $16,6 \%$ dos alunos do diurno gasta mais de 3h30min no seu percurso diário, e entre os estudantes do noturno, este número chega a $21,7 \%$. Ao todo, $63 \%$ dos estudantes perdem não mais que $2 \mathrm{~h} 30$ no trânsito da cidade do Rio de Janeiro, o que sugere também que o público discente em pauta estuda, trabalha e realiza estágios nas proximidades de suas casas.

\footnotetext{
${ }^{3}$ O mapa 1 foi construído a partir do CEP informado por 100 estudantes do diurno e 154 do noturno.
} 


\section{Mapa 1 - Distribuição geográfica dos estudantes por turno}

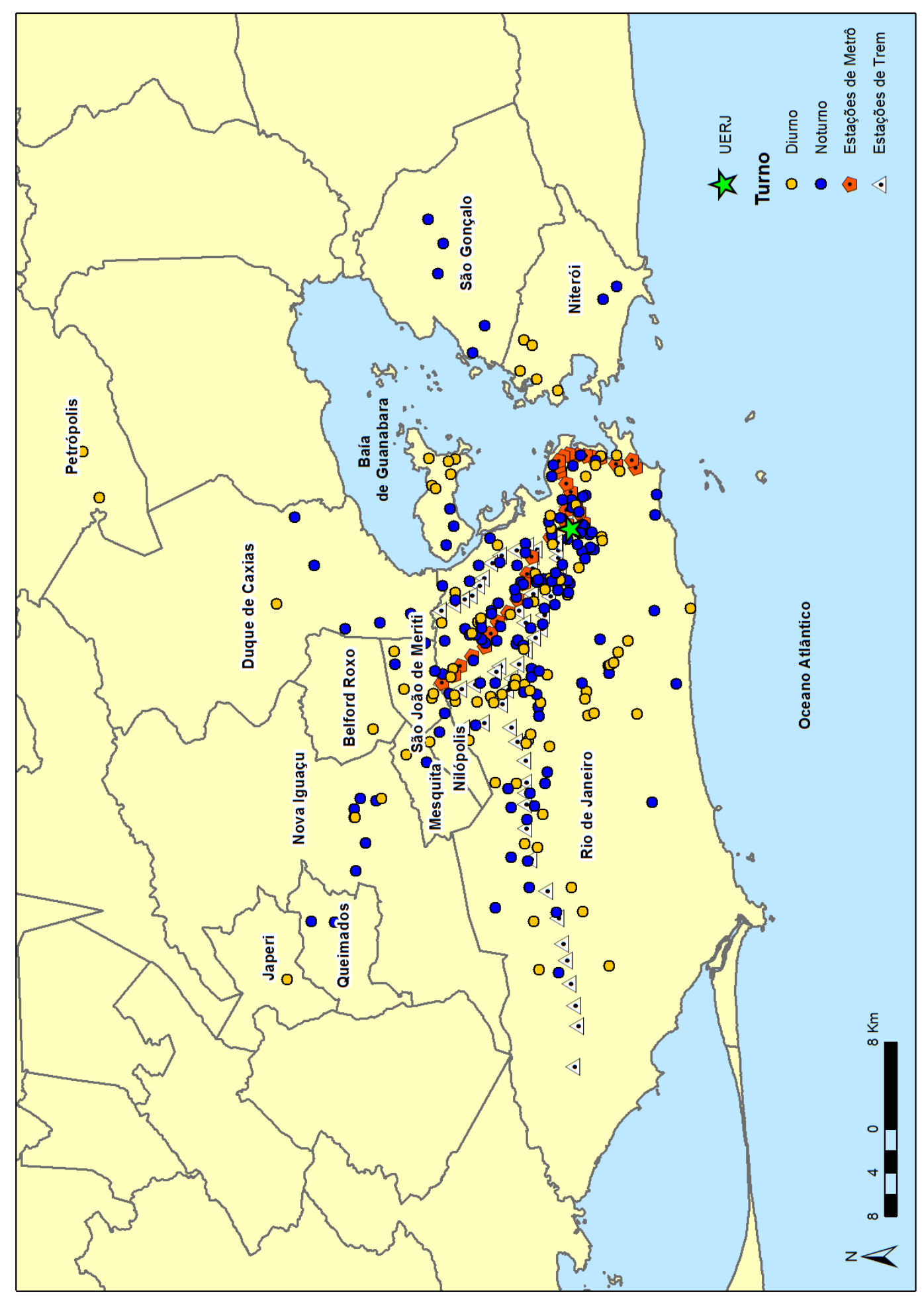

Fonte: Questionário SOCED / Pesquisa: Cursos de pedagogia - estudos de caso e desafios à produção de qualidade do ensino fundamental. 


\subsection{2}

\section{Situação socioeconômica}

Um pouco mais velhos e com responsabilidades financeiras em casa, 72,7\% dos estudantes do noturno trabalham, como observamos na tabela 2. Entre estes, $38,1 \%$ são professores e outros $18,1 \%$ trabalham na área da educação, como analisado na tabela 3. Entre os estudantes do curso diurno, apenas 23,7\% trabalham. Entre os que trabalham pela manhã, o interessante é que 53,1\% são professores e outros $18,8 \%$ atuam na educação. Entendemos que a possibilidade de se conjugar trabalho formal e estudo para os estudantes do diurno é facilitada para aqueles que atuam na área da educação, dentro ou fora da sala de aula, o que pode ser explicado pela possibilidade do trabalho em tempo parcial viável na carreira docente.

Tabela 2 - Situação de trabalho dos estudantes.

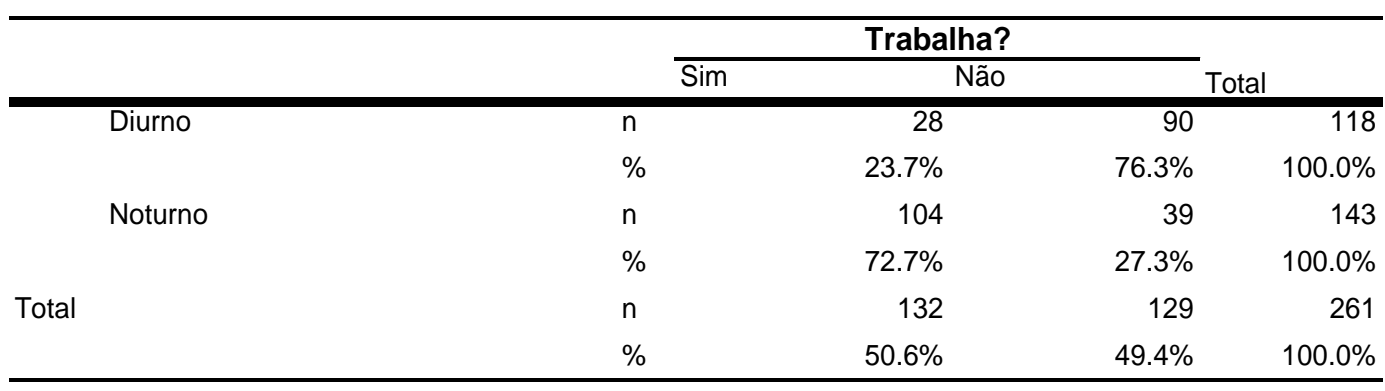

Fonte: Questionário SOCED / Pesquisa: Cursos de pedagogia - estudos de caso e desafios à produção de qualidade do ensino fundamental.

A profissão docente como vemos em Gatti e Barreto (2009) não é uma atividade considerada como bico ou complementar a outra atividade profissional. Ela é a atividade principal para a grande maioria dos professores brasileiros. Em Luis Pereira (1969), observamos que a atividade docente possibilitava nas décadas de 50 e 60 que a professora conjugasse o trabalho de professor com as atividades domésticas, questão esta apontada como forte motivo da feminização do magistério. Nossos dados indicam que para o professor dar continuidade aos seus estudos em nível superior, a flexibilidade do horário de trabalho docente, que 
pode ser parcial, permite que eles estudem pela manhã, caso tenham interesse e consigam organizar seu turno de trabalho, como observamos entre os $25 \%$ de estudantes que atuam profissionalmente no turno diurno. Entre os estudantes que são professores do curso noturno, 36,7\% declararam que trabalham em período integral.

Tabela 3 - Área de trabalho dos estudantes

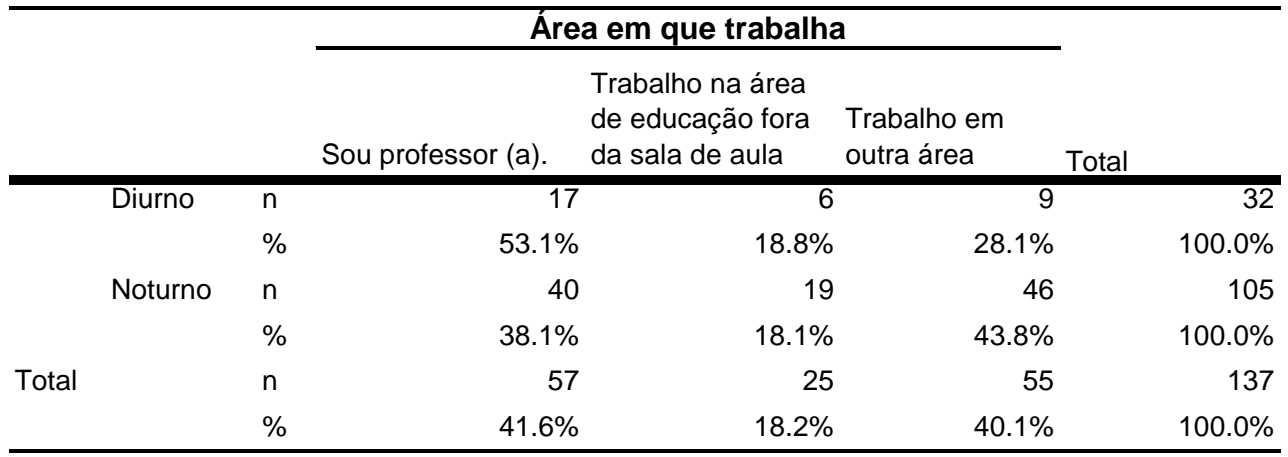

Fonte: Questionário SOCED / Pesquisa: Cursos de pedagogia - estudos de caso e desafios à produção de qualidade do ensino fundamental.

Os dados da tabela 3 indicam também que a porcentagem de 40,1\% de estudantes que trabalham nas mais diferentes áreas pode representar a necessidade dos estudantes pela titulação. Durante a aplicação dos questionários, conversei com alguns estudantes que mencionaram que já trabalhavam em outras áreas que pagavam melhor que a profissão de professor e que precisavam da titulação, é o caso, por exemplo, de bombeiros e militares.

Com relação ao regime de trabalho, conforme tabela $4,48,5 \%$ dos estudantes da noite trabalham em regime de tempo integral, em contrapartida com os 3,2\% dos que estudam pela manhã. Coulon (2008, p. 143) nota que para o estudante trabalhador o ingresso na vida universitária exige primeiramente "que ele encontre no trabalho, fatias de horários para poder frequentar as aulas, impor esses horários no emprego ou começar a trabalhar em meio período". Essa negociação entre o horário de trabalho, e o horário de estudo, é, inclusive, como observamos em nossos dados, realizada na universidade, junto aos professores. Os estudantes tentam negociar atrasos ou saídas mais cedo das aulas, na tentativa de conjugar estudo e trabalho. 
Tabela 4 - Regime de trabalho dos estudantes

\begin{tabular}{|c|c|c|c|c|c|}
\hline & & & \multicolumn{2}{|c|}{ Regime de trabalho } & \multirow[b]{2}{*}{ Total } \\
\hline & & & Tempo parcial & Tempo integral & \\
\hline & \multirow[t]{2}{*}{ Diurno } & $\mathrm{n}$ & 30 & 1 & 31 \\
\hline & & $\%$ & $96.8 \%$ & $3.2 \%$ & $100.0 \%$ \\
\hline & \multirow[t]{2}{*}{ Noturno } & $\mathrm{n}$ & 53 & 50 & 103 \\
\hline & & $\%$ & $51.5 \%$ & $48.5 \%$ & $100.0 \%$ \\
\hline \multirow[t]{2}{*}{ Total } & & $\mathrm{n}$ & 83 & 51 & 134 \\
\hline & & $\%$ & $61.9 \%$ & $38.1 \%$ & $100.0 \%$ \\
\hline
\end{tabular}

Fonte: Questionário SOCED / Pesquisa: Cursos de pedagogia - estudos de caso e desafios à produção de qualidade do ensino fundamental.

Durante as entrevistas com os professores, alguns comentaram sobre alunos que trabalham no turno noturno e que pela manhã vão diretamente para a universidade após o trabalho, sem qualquer descanso. Além disso, presenciei uma conversa entre um aluno e a professora que por mim seria entrevistada. Ele tentava negociar sua frequência às aulas, já que trabalhava durante toda noite e morava em outro município, levando cerca de uma hora e meia para chegar à UERJ. A professora foi direta e clara, dizendo que ele não poderia, portanto, pegar uma disciplina às sete da manhã. Há também casos de alunos que trabalham em shoppings no período tarde/noite, como pude verificar em conversas informais com estes estudantes, durante ou após a aplicação dos questionários. Essas situações explicam como estudantes do curso diurno conseguem, ao menos em parte mais inicial do curso, manter vínculos empregatícios em tempo integral.

O trabalho formal dificulta a realização de estágios por estes estudantes, tanto os estágios profissionais, ou seja, estágios remunerados como os administrativos oferecidos pela universidade, ou estágios acadêmicos, como os de iniciação científica, como os estágios curriculares, requisito fundamental para a conclusão do curso. Observamos na tabela 5 que 41,8\% dos estudantes do noturno não realizam qualquer tipo de estágio, percentual que cai para $30,5 \%$ entre os estudantes do diurno. Alguns estudantes do curso noturno comentaram sobre sua dificuldade em conseguir realizar os quatro estágios curriculares do curso, cada um com 60h. Geralmente, estes estágios são deixados para os períodos finais e tais estudantes buscam negociar com seu trabalho. Normalmente, eles conseguem 
uma tarde, ou o realizam em seu dia de folga, quando este ocorre em dia de semana. Muitos tiram férias para dar conta das atividades acadêmicas. Uma aluna do noturno que se mostrou bastante organizada, me mostrou seu horário semanal, com marcação de determinada atividade para cada horário do dia, incluindo trabalho, e os horários específicos para cada estágio. Ao ser questionada se daria conta de cumprir toda a carga horária, ela me disse que sim, que já estava tudo planejado, quando ela terminasse as horas do estágio $\mathrm{X}$, iria iniciar o $\mathrm{Y}$ e, ao final do semestre, conseguiria realizar tudo, mas acrescentou: "não posso perder um dia sequer, senão me complica" [E, noturno].

\section{Tabela 5 - Distribuição dos estudantes que realizam estágio}

\begin{tabular}{|c|c|c|c|c|c|}
\hline & & \multicolumn{3}{|c|}{ Faz estágio } & \multirow[b]{2}{*}{ Total } \\
\hline & & Não & $\begin{array}{l}\text { Sim, NÃO } \\
\text { remunerado }\end{array}$ & $\begin{array}{c}\text { Sim, } \\
\text { remunerado } \\
\end{array}$ & \\
\hline \multirow{2}{*}{ Diurno } & $\mathrm{n}$ & 32 & 19 & 54 & 105 \\
\hline & $\%$ & $30.5 \%$ & $18.1 \%$ & $51.4 \%$ & $100.0 \%$ \\
\hline \multirow{2}{*}{ Noturno } & $\mathrm{n}$ & 66 & 36 & 56 & 158 \\
\hline & $\%$ & $41.8 \%$ & $22.8 \%$ & $35.4 \%$ & $100.0 \%$ \\
\hline \multirow{2}{*}{ Total } & $\mathrm{n}$ & 98 & 55 & 110 & 263 \\
\hline & $\%$ & $37.3 \%$ & $20.9 \%$ & $41.8 \%$ & $100.0 \%$ \\
\hline
\end{tabular}

Fonte: Questionário SOCED / Pesquisa: Cursos de pedagogia - estudos de caso e desafios à produção de qualidade do ensino fundamental.

O estágio remunerado é exercido por $51,4 \%$ dos que estudam pela manhã, o que permite ao estudante se manter durante seus estudos, em atividade usualmente ligada à sua área de atuação. Uma de nossas professoras entrevistadas comenta sobre esta questão: "Eu já arranjei estágios pra alunos excelentes que não puderam sair de um trabalho, de telemarketing da Oi, por exemplo. E como é que essa menina que é excelente vai se inserir no mercado [de seu campo de atuação]?" [P8]. Percebemos que, apesar de o aluno do curso da manhã em sua maioria não trabalhar em atividades formais, ele realiza estágios, sejam eles profissionais, acadêmicos ou curriculares. Vargas e Paula (2013, p. 467) entendem que tal aluno 
"não trabalhador" configura o "estudante em tempo integral", por oposição ao status de "trabalhador-estudante" ou de "estudante-trabalhador", sugerindo uma ótima disponibilidade de tempo para a realização de estudos. Liberado da obrigação de se sustentar, o estudante em tempo integral (...) poderá, no momento oportuno, trilhar o ritual de estágio que antecede a boa colocação profissional.

Os estudantes do turno da manhã se encontram mais próximos desta situação de "estudante em tempo integral". Muitos conseguem se dedicar aos estudos e realizar estágios na área de formação, tendo condições de se inserirem no mercado de trabalho na área de atuação, como destaca a professora [P8].

Quanto à escolarização dos pais e mães de nossos estudantes, percebemos um nível de ensino mais elevado que os normalmente encontrados pelos dados mais gerais revelados pelos estudiosos Dias et al. (2008) também entre os estudantes de uma universidade pública. Como se pode ver na tabela abaixo, boa parte das mães de nossos estudantes possui nível médio ou superior. Estes dados apresentam diferença mais marcante entre os estudantes dos dois turnos pesquisados. Percebemos que as mães dos estudantes do diurno possuem maior escolaridade, sendo que 28,1\% declaram ter formação em nível superior. Já entre as mães dos estudantes do noturno a formação neste nível de ensino é de $16,8 \%$. As taxas referentes ao ensino médio também revelam uma diferença de mais de $12 \%$ entre os dois turnos, $30,8 \%$ no noturno e $42,1 \%$ no diurno. A formação escolar básica também se apresenta mais baixa entre as mães dos estudantes do noturno, o que indica que estes estudantes representam uma geração com formação bastante superior à de seus pais, sendo, na maioria das vezes, os primeiros a concluírem o ensino superior na família. Isso também acontece entre os estudantes do curso diurno, como exemplificado nos seguintes excertos: "Ninguém da minha família possuía curso superior" [aluna do $7^{\circ}$ período, manhã], ou "sou uma das poucas pessoas da minha família que entraram para a faculdade" [aluna do $8^{\circ}$ período, manhã].

O nível de escolaridade da mãe (gráfico 2) normalmente é um indicativo da origem socioeconômica de um indivíduo. A formação educacional da família reflete diretamente nas condições de estes estudantes obterem sucesso em sua trajetória escolar, especialmente porque está ligada ao capital cultural/escolar desses alunos, como vemos em Bourdieu (2012). 
Gráfico 2 - Nível de escolaridade da mãe

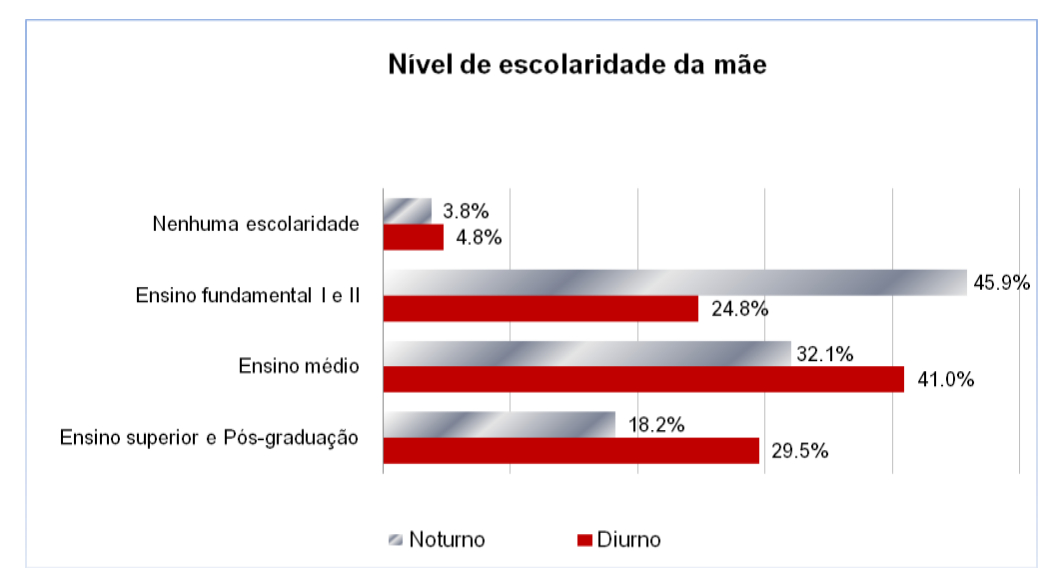

Fonte: Questionário SOCED / Pesquisa: Cursos de pedagogia - estudos de caso e desafios à produção de qualidade do ensino fundamental.

Por outro lado, os dados sobre a formação paterna se apresentam como mais baixos que aqueles da formação materna de nossos estudantes (gráfico 3). Ainda assim, a formação dos pais dos estudantes do noturno é mais baixa que a dos pais dos que estudam pela manhã.

\section{Gráfico 3 - Nível de escolaridade do pai}

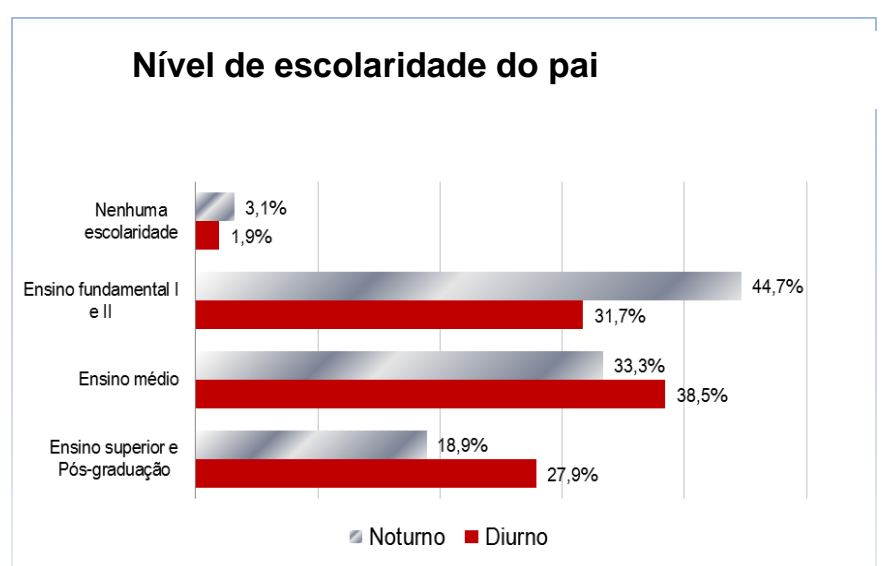

Fonte: Questionário SOCED / Pesquisa: Cursos de pedagogia - estudos de caso e desafios à produção de qualidade do ensino fundamental. 
Estas informações nos permitem compreender o volume de capital cultural herdado da família dos estudantes. Conjugando os dados de formação dos pais e mães de nossos estudantes, há uma indicação de que por volta de $75 \%$ de nossos estudantes serão os primeiros a concluírem o nível superior em suas famílias. Portanto, o ingresso no ensino superior já representa um ganho de capital cultural/escolar para estes estudantes.

$\mathrm{Na}$ tentativa de detectar diferenças entre os alunos do diurno e noturno com relação à situação econômica, lançamos mão da renda familiar como indicativo das condições econômicas dos estudantes (tabela 6). Percebemos que, apesar da semelhança na proporcionalidade na renda dos estudantes dos dois turnos, os estudantes do noturno possuem renda familiar um pouco mais elevada nas faixas mais altas que os estudantes do diurno, o que provavelmente se deve ao trabalho formal exercido pela maioria destes estudantes. Apenas na faixa de renda mais alta, acima de 10 salários mínimos, que há um leve aumento em favor dos estudantes do curso diurno, $15,3 \%$ entre os que estudam pela manhã e 10,4\% entre os que estudam à noite.

\section{Tabela 6 - Renda mensal da família}

\begin{tabular}{|c|c|c|c|c|c|c|c|c|c|c|}
\hline & & & \multicolumn{7}{|c|}{ Renda mensal de sua família } & \multirow[b]{2}{*}{ Total } \\
\hline & & & $\begin{array}{l}\text { Até } 1 \text { salário } \\
\text { mínimo } \\
(\mathrm{R} \$ 678,00)\end{array}$ & $\begin{array}{l}\text { Até } 1,5 \text { salário } \\
\text { mínimo (até } R \$ \\
1.017,00 \text { ) }\end{array}$ & $\begin{array}{l}\text { Acima de } 1,5 \\
\text { até } 3 \text { salários } \\
\text { mínimos }(R \$ \\
1.017,00 \text { a } R \$ \\
2.034,00) .\end{array}$ & $\begin{array}{l}\text { Acima de } 3 \text { até } \\
4,5 \text { salários } \\
\text { mínimos }(\mathrm{R} \$ \\
2.034,00 \text { a } \mathrm{R} \$ \\
3.051,00) \text {. }\end{array}$ & $\begin{array}{l}\text { Acima de } 4,5 \\
\text { até } 6 \text { salários } \\
\text { mínimos }(R \$ \\
3.051,00 \text { a } R \$ \\
4.068,00)\end{array}$ & $\begin{array}{l}\text { Acima de } 6 \text { até } \\
10 \text { salários } \\
\text { mínimos }(\mathrm{R} \$ \\
4.068,00 \text { a } \mathrm{R} \$ \\
6.780,00) .\end{array}$ & $\begin{array}{l}\text { Acima de } 10 \\
\text { (mais de } R \$ \\
6.780,00) \text {. }\end{array}$ & \\
\hline & \multirow[t]{2}{*}{ Diurno } & $n$ & 4 & 13 & 26 & 22 & 20 & 15 & 18 & 118 \\
\hline & & $\%$ & $3.4 \%$ & $11.0 \%$ & $22.0 \%$ & $18.6 \%$ & $16.9 \%$ & $12.7 \%$ & $15.3 \%$ & $100.0 \%$ \\
\hline & \multirow[t]{2}{*}{ Noturno } & $n$ & 4 & 20 & 23 & 36 & 23 & 23 & 15 & 144 \\
\hline & & $\%$ & $2.8 \%$ & $13.9 \%$ & $16.0 \%$ & $25.0 \%$ & $16.0 \%$ & $16.0 \%$ & $10.4 \%$ & $100.0 \%$ \\
\hline \multirow[t]{2}{*}{ Total } & & $n$ & 8 & 33 & 49 & 58 & 43 & 38 & 33 & 262 \\
\hline & & $\%$ & $3.1 \%$ & $12.6 \%$ & $18.7 \%$ & $22.1 \%$ & $16.4 \%$ & $14.5 \%$ & $12.6 \%$ & $100.0 \%$ \\
\hline
\end{tabular}

Fonte: Questionário SOCED / Pesquisa: Cursos de pedagogia - estudos de caso e desafios à produção de qualidade do ensino fundamental.

$\mathrm{Na}$ tabela 6, verificamos que entre os estudantes do noturno, 32,7\% declaram obter renda familiar de até três salários mínimos, já entre os estudantes do diurno, esse percentual sobe para $36,4 \%$. Com rendimentos familiares entre três e dez salários, encontramos $57 \%$ entre os estudantes do noturno e $48,2 \%$ do diurno. 
Comparando com os dados que indicam a participação do estudante na renda familiar (tabela 7), percebemos que apenas 28,7\% do total de nossos estudantes não possuem alguma participação e são totalmente custeados pela família (apenas $14,3 \%$ entre os alunos do noturno e $45,8 \%$ entre os alunos do diurno). Por outro lado, nossos estudantes, mesmo aqueles que trabalham, não são os principais responsáveis financeiros de suas famílias, apesar de que há uma porcentagem bem maior entre os estudantes do noturno, 22,9\%, que ocupa esta função. Pais e mães continuam a exercer este papel, especialmente pelo fato de que a grande maioria de nossos respondentes (mais de $85 \%$ ) é solteira.

Tabela 7 - Principal responsável financeiro da família

\begin{tabular}{|c|c|c|c|c|c|c|c|c|c|}
\hline & & & \multicolumn{6}{|c|}{ O (a) principal responsável financeiro (a) de sua família } & \multirow[b]{2}{*}{ Total } \\
\hline & & & $\begin{array}{l}\text { Você } \\
\text { mesmo(a) }\end{array}$ & Cônjuge & Pai & Mãe & Pai e Mãe & $\begin{array}{l}\text { Outra } \\
\text { pessoa }\end{array}$ & \\
\hline & \multirow[t]{2}{*}{ Diurno } & $\mathrm{n}$ & 5 & 12 & 51 & 27 & 19 & 7 & 121 \\
\hline & & $\%$ & $4.1 \%$ & $9.9 \%$ & $42.1 \%$ & $22.3 \%$ & $15.7 \%$ & $5.8 \%$ & $100.0 \%$ \\
\hline & \multirow[t]{2}{*}{ Noturno } & $\mathrm{n}$ & 33 & 19 & 35 & 28 & 26 & 3 & 144 \\
\hline & & $\%$ & $22.9 \%$ & $13.2 \%$ & $24.3 \%$ & $19.4 \%$ & $18.1 \%$ & $2.1 \%$ & $100.0 \%$ \\
\hline \multirow[t]{2}{*}{ Total } & & $\mathrm{n}$ & 38 & 31 & 86 & 55 & 45 & 10 & 265 \\
\hline & & $\%$ & $14.3 \%$ & $11.7 \%$ & $32.5 \%$ & $20.8 \%$ & $17.0 \%$ & $3.8 \%$ & $100.0 \%$ \\
\hline
\end{tabular}

Fonte: Questionário SOCED / Pesquisa: Cursos de pedagogia - estudos de caso e desafios à produção de qualidade do ensino fundamental.

Os estudantes que possuem alguma atividade remunerada ou trabalham formalmente geralmente custeiam seus estudos e gastos pessoais. Como vemos na tabela 7, entre os que estudam à noite, 67,9\% são inteiramente responsáveis pelo custeio de seus estudos, já entre os alunos do diurno, são 24,6\%. Tais percentuais são bastante próximos entre os que trabalham nos dois turnos, como vimos. 
Tabela 8 - Custeio dos estudos

\begin{tabular}{|c|c|c|c|c|c|c|c|c|}
\hline & & & \multicolumn{5}{|c|}{ Em relação ao custeio dos seus estudos } & \\
\hline & & & $\begin{array}{l}\text { Sou } \\
\text { inteiramente } \\
\text { responsável }\end{array}$ & Recebo bolsa & $\begin{array}{l}\text { Sou financiado } \\
\text { por familiares }\end{array}$ & Outros & \multicolumn{2}{|c|}{ Total } \\
\hline & \multirow[t]{2}{*}{ Diurno } & $\mathrm{n}$ & 29 & 33 & 5 & & 2 & 118 \\
\hline & & $\%$ & $24.6 \%$ & $28.0 \%$ & $45.8 \%$ & & $1.7 \%$ & $100.0 \%$ \\
\hline & \multirow[t]{2}{*}{ Noturno } & $\mathrm{n}$ & 95 & 23 & 2 & & 2 & 140 \\
\hline & & $\%$ & $67.9 \%$ & $16.4 \%$ & $14.3 \%$ & & $1.4 \%$ & $100.0 \%$ \\
\hline \multirow[t]{2}{*}{ Total } & & $\mathrm{n}$ & 124 & 56 & 7 & & 4 & 258 \\
\hline & & $\%$ & $48.1 \%$ & $21.7 \%$ & $28.7 \%$ & & $1.6 \%$ & $100.0 \%$ \\
\hline
\end{tabular}

Fonte: Questionário SOCED / Pesquisa: Cursos de pedagogia - estudos de caso e desafios à produção de qualidade do ensino fundamental.

Este dado corrobora a afirmação de Comin e Barbosa (2011) sobre o fato de que muitos dos estudantes do ensino superior "trabalham para estudar". Vargas e Costa de Paula (2013, p. 465) ressaltam, de modo semelhante, que "por vezes o trabalho dificulta a escolarização, por vezes a ausência de trabalho dificulta a escolarização". No caso de nossos estudantes do noturno, a grande maioria parece se manter em sua escolarização, exatamente pelo fato de trabalharem, o que é confirmado pelos dados da tabela 8 .

Diante da situação econômica de nossos estudantes, fica claro que há melhores condições financeiras entre os alunos do curso diurno. $\mathrm{O}$ fato de 45,8\% dos estudantes do diurno terem seus estudos custeados pelos familiares e menos de um quarto declarar que custeia totalmente seus estudos, percentual este próximo ao dos entrevistados que afirmam trabalhar, indica que tais estudantes possuem melhores condições de se dedicarem à sua formação universitária. Sem compromissos financeiros, eles podem se beneficiar das oportunidades acadêmicas oferecidas pela universidade, seja através de programas de bolsas, seja na participação dos eventos acadêmicos. Além disso, tal condição os permite usufruir os demais espaços da universidade, como biblioteca e laboratórios. Conhecer essas diferenças de composição e volume de capital econômico e capital cultural/escolar de nossos estudantes possibilita compreender as diferenças de habitus, de herança cultural, de trajetórias escolares que indicam processos diferenciados na formação acadêmica discente nos diferentes turnos em questão. 


\subsection{3}

\section{Trajetória escolar e escolha profissional}

Entre o nosso corpus de estudantes, $72 \%$ dos que estudam à noite cursaram a maior parte do ensino fundamental I e II em escolas públicas. Já entre os que estudam no período diurno, 60\% estudaram em escolas privadas. Dados estes bastante semelhantes aos encontrados no ensino médio, como observa-se na tabela 9. A grande maioria, isto é, 78,9\% dos estudantes dos dois turnos, cursou o ensino médio no turno da manhã. Apenas $10,3 \%$ o realizaram todo no noturno ou em grande parte neste turno de ensino.

\section{Tabela 9 - Tipo de instituição onde cursou o ensino médio}

\begin{tabular}{|c|c|c|c|c|c|}
\hline & & \multicolumn{3}{|c|}{ Tipo de escola onde concluiu o ensino médio } & \multirow[b]{2}{*}{ Total } \\
\hline & & $\begin{array}{c}\text { Pública } \\
\text { (municipal/estadual) }\end{array}$ & Pública (federal) & Privada & \\
\hline \multirow[t]{2}{*}{ Diurno } & $\mathrm{n}$ & 157 & 13 & 193 & 363 \\
\hline & $\%$ & $43.3 \%$ & $3.6 \%$ & $53.2 \%$ & \\
\hline \multirow[t]{2}{*}{ Noturno } & $\mathrm{n}$ & 276 & 5 & 152 & 433 \\
\hline & $\%$ & $63.7 \%$ & $1.2 \%$ & $35.1 \%$ & \\
\hline Total & $\mathrm{n}$ & 433 & 18 & 345 & 796 \\
\hline
\end{tabular}

Fonte: Questionário SOCED / Pesquisa: Cursos de pedagogia - estudos de caso e desafios à produção de qualidade do ensino fundamental.

A trajetória escolar de nossos estudantes aponta, mais uma vez, que os que estudam no curso diurno possuem uma trajetória escolar realizada em instituições particulares, enquanto que a maioria dos que estudam no noturno foram alunos de escolas municipais e/ou estaduais. Esses dados sugerem que os estudantes do curso diurno possuem capital herdado superior aos estudantes do noturno. Para Setton (2005, p. 79), "a posse de um certo capital cultural e de um ethos familiar predisposto a valorizar e incentivar o conhecimento escolar seriam importantes elementos para se alcançar um sucesso acadêmico". Os pais dos estudantes do curso diurno demonstram uma tendência a oferecer, desde a infância, uma educação que eles julgam ser de melhor qualidade para seus filhos, colocando-os 
em escolas particulares. No julgamento da autora, estas são formas de investimento pedagógico dos familiares sobre seus filhos, que estão ligadas

ao empenho da família em um projeto de ascensão social via sistema de ensino. São práticas relativas à procura por uma escola particular ou por uma melhor escola pública da região, ou mesmo no oferecimento de condições propícias aos estudos na compra de livros e material didático (Setton, 2005, p. 84).

Outro indicativo do capital escolar/cultural de nossos estudantes está na resposta ao domínio de língua inglesa (tabela 10), aspecto este indicativo de melhor possibilidade de aprovação no vestibular (Dias, et al., 2008).

\section{Tabela 10 - Domínio de língua inglesa}

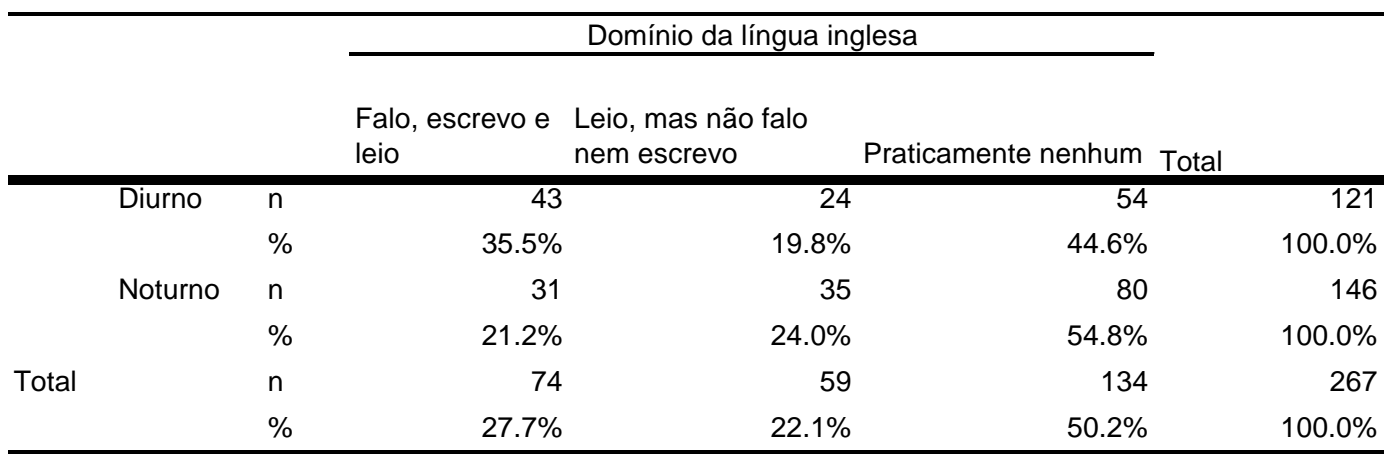

Fonte: Questionário SOCED / Pesquisa: Cursos de pedagogia - estudos de caso e desafios à produção de qualidade do ensino fundamental.

Ao serem questionados se dominavam a língua estrangeira em pauta, a partir das três opções observadas na tabela 10, 35,5\% dos estudantes do diurno e 21,2\% dos estudantes do noturno declararam possuir domínio da língua inglesa, nas habilidades de fala, escrita e leitura. Entre aqueles que afirmam não possuir praticamente nenhum domínio do idioma, $54,8 \%$ são alunos do noturno.

Este é mais um indicativo da condição econômica superior destes estudantes sobre os alunos do noturno. Esses estudantes provavelmente tiveram acesso a cursos de língua estrangeira extracurriculares durante sua trajetória escolar, oportunidade esta oferecida em menor escala a estudantes do noturno. Quando questionados sobre se já haviam realizado viagem ao exterior, os dados aparecem mais próximos entre os dois turnos, 29,5\% para estudantes do diurno e 20,3\% para 
estudantes do noturno. Tais dados alertam, mais uma vez, para as condições diferenciadas de acúmulo de capital cultural/escolar familiar herdado pelo corpo discente dos dois turnos estudados.

Com relação à escolha do curso, verificamos respostas semelhantes entre os dois grupos de estudantes, 66,5\% escolheram o curso de pedagogia como primeira opção no vestibular $(62,9 \%$ entre os estudantes do diurno, e $69 \%$ entre os do noturno). Em média, $47,7 \%$ dos estudantes de cada turno afirmam que uma das principais razões da escolha pelo curso se deu pelo interesse em ser professor ou por já o serem. Com percentuais bastante semelhantes, 49,1\% do corpo de estudantes (53,2\% noturno e 46,1\% diurno) escolheram o curso por já atuarem ou desejo de atuar na área da educação.

Perguntados informalmente em um grupo de doze estudantes do oitavo período noturno, apenas duas estudantes declararam querer ser professoras. Uma realiza estágio remunerado na área, enquanto que a outra já atua como docente. Os demais mencionaram que pretendem fazer outras coisas. Um pretende seguir na pós-graduação, outras três, inclusive uma aluna que já atua na área de empresa, pretende trabalhar nesta mesma área, e os demais afirmaram aguardar as oportunidades que surgirem, especialmente na função de pedagoga, ocupação de uma das estudantes, que enquanto secretária de um curso de pós-graduação, auxiliou na montagem e organização do curso. Tais oportunidades de atuação surgem, na visão de nossos estudantes, a partir de concursos. Alguns mencionaram que querem fazer concurso para a carreira militar.

Ao serem questionados sobre o porquê da não escolha pela profissão docente, os fatores mencionados por Gatti (2009), a partir das respostas dos estudantes do ensino médio, são relembrados. A complexidade do trabalho docente associada à baixa remuneração e baixa valorização social desanimam esses profissionais que, apesar de quase já formados na área, não pretendem atuar na docência.

Percebemos ainda que entre os estudantes que trabalham em outras áreas que não a docência, (tabela 11) o interesse em ser professor é ainda menor. Entre estes, 58,6\% de estudantes dos dois turnos, incluindo a área da educação, apenas $28 \%$ afirmam que pretendem ser professores $(38,5 \%$ entre os que estudam pela 
manhã e $26,1 \%$ entre os que estudam à noite). Observamos, portanto, que os trabalhadores do noturno de outras áreas fora da docência, se interessam ainda menos pela profissão de professor, já que 73,9\% revelaram desinteresse pela profissão docente. Esse dado pode ser explicado pela inserção profissional desses estudantes, motivo pelo qual eles vislumbram outras possibilidades de atuação profissional.

\section{Tabela 11 - Quero ser professor x Não sou professor atualmente}

\begin{tabular}{|c|c|c|c|c|}
\hline & & \multicolumn{2}{|c|}{ Quero ser professor(a) } & \multirow{2}{*}{ Total } \\
\hline & & Sim & Não & \\
\hline \multirow{2}{*}{ Diurno } & $\mathrm{n}$ & 5 & 8 & 13 \\
\hline & $\%$ & $38.5 \%$ & $61.5 \%$ & $100.0 \%$ \\
\hline \multirow{2}{*}{ Noturno } & $\mathrm{n}$ & 18 & 51 & 69 \\
\hline & $\%$ & $26.1 \%$ & $73.9 \%$ & $100.0 \%$ \\
\hline \multirow{2}{*}{ Total } & $\mathrm{n}$ & 23 & 59 & 82 \\
\hline & $\%$ & $28.0 \%$ & $72.0 \%$ & $100.0 \%$ \\
\hline
\end{tabular}

Fonte: Questionário SOCED / Pesquisa: Cursos de pedagogia - estudos de caso e desafios à produção de qualidade do ensino fundamental.

Esse conjunto de informações nos leva a questionar o tipo de aproveitamento que boa parte dos estudantes que cursam pedagogia pode tirar de um curso de formação docente, com interesses tão diversos dentro do curso. Tal fator pode explicar, em parte, a falta de interesse que muitos professores notam entre parte dos estudantes.

O tipo de formação realizada no ensino médio pode trazer outras contribuições para a compreensão da escolha do curso por parte de nossos estudantes. Nossos dados indicam que $24 \%$ de nossos estudantes são oriundos de cursos de formação de docente no nível médio, ou ensino médio normal (28,5\%, noturno e 15,8\%, diurno). Percentual semelhante foi encontrado entre os estudantes que enviaram seus relatos, 15 alunos, aproximadamente $30 \%$, são oriundos deste nível de ensino, 10 alunos do noturno e 5 do diurno. Para os 
professores, estes alunos que são oriundos do curso normal geralmente chegam com o objetivo de atuarem na área da educação.

Tem aquelas alunas que vêm do ensino médio normal, que já estão seduzidas pela educação há muito tempo, levantam mesmo a bandeira da educação, da sala de aula, defendem a docência como trabalho para a vida profissional delas, como campo de atuação do pedagogo e onde elas querem se inserir. [P7]

Através de nossos respondentes, percebemos que a maioria dos que cursaram o ensino médio na modalidade normal opta pelo curso a fim de dar continuidade à preparação para a docência, por sempre "sonhar em ser professora" e por se sentir "despreparada para atuar", buscando assim, aprofundar os estudos na área da docência.

A escolha do curso por ser um dos que possuem menor relação candidato vaga aparece como fator de escolha para $22,8 \%$ (19,9\% noturno e $26,4 \%$ no diurno). A escolha pelo curso de pedagogia normalmente está ligada à menor concorrência do vestibular, corroborando os estudos de Carrano (2009) e Dias et al. (2008), que revelam que as notas dos candidatos às vagas dos cursos de pedagogia estão dentre as mais baixas dos vestibulares de todo o país, o que também verificamos na instituição pesquisada.

O curso da UERJ oferece um número muito grande de vagas, isso influencia diretamente a seleção dos estudantes, como percebemos na fala de um de nossos entrevistados.

[Em Pedagogia] não tem seleção nenhuma. Primeiro não se completa o número de vagas. Aí tem milhares de reclassificações. [P1]

Nós temos uma questão aqui na faculdade que é ter muita vaga pra demanda que realmente existe, então a gente fica fazendo reclassificação, a faculdade faz reclassificações, reclassificações, reclassificações. Então vêm alunos cuja opção em pedagogia era terceira, quarta, quinta não era primeira opção. [P7]

Como vimos, apesar de a maioria dos estudantes ter escolhido o curso como primeira opção, isso não ocorreu para 41,7\% dos alunos do turno da manhã e para $28,1 \%$ dos que estudam à noite. Portanto, para esses estudantes, $34,2 \%$ ao todo, 
pedagogia não foi sua opção no vestibular, e eles foram reclassificados de acordo com o número de vagas.

Encontramos na fala de um dos estudantes, uma exemplificação desta situação.

Optei por pedagogia porque, na verdade, não conseguia passar para direito, na UERJ (...) Durante o ano de meu vestibular, analisava muito as relações candidato/vaga. Conforme a minha nota no primeiro exame de qualificação, fui redirecionando meus passos. Foi questão de estratégia, pois com a idade que tinha, não poderia ficar mais esperando pela minha graduação em nível superior. (R6, Estudante do noturno, originalmente do curso diurno)

O estudante de pedagogia faz parte de um campo social definido por estrutura e lógica próprias e como "um espaço de possibilidades" (Brandão, 2010, p. 231). Nesse campo, ele utiliza de estratégias que estão relacionadas "aos meios disponíveis (capitais) e aos objetivos a alcançar" (ibidem), que, no caso, é o de melhorar a posição que ele detém no campo social. Tal situação pode significar o que Bourdieu chama de escolha pelo possível, ou seja, já que o estudante de origem socioeconômica baixa não possui base escolar suficiente para passar nos exames de seleção dos cursos de maior prestígio, ele lança mão da estratégia mais razoável para ingresso no ensino superior (Bourdieu, 2006), nesta circunstância, o ingresso no curso de pedagogia, curso de baixa relação/candidato vaga e de menor custo. O próprio estudante menciona que foi redirecionando suas decisões a partir da situação de não obtenção de nota suficiente para aprovação no vestibular no curso desejado (e que ele deixará para o futuro, como acrescenta). Desta forma, avalia-se possibilidades e recorre-se à estratégia que melhor possibilite a entrada no ensino superior.

Dos 57 estudantes que atenderam ao nosso pedido para relatar sua experiência, 15, ou seja, mais de $30 \%$ escolheram pedagogia como uma estratégia para entrar no ensino superior. Expressões como "escolhi pedagogia por achar que seria um curso fácil", "cheguei ao curso depois de dois anos tentando o vestibular para outras áreas", "porque tinha um menor número candidato por vaga e eu tinha medo de escolher outro curso e não passar no vestibular", "tinha a intenção de pedir transferência interna para o curso de jornalismo", "entrei na pedagogia como 
segunda opção" são exemplos das estratégias utilizadas pelos estudantes para ingresso no ensino superior. Observamos ainda que entre aqueles que realizam cursos preparatórios em pré-vestibulares sociais, a utilização desta estratégia aparece de modo bem claro. O foco dos estudantes nestes casos parece ser a entrada no ensino superior, em uma universidade pública, independentemente do curso. Consoante Bourdieu, esses estudantes trazem em si, "isto é, em seu habitus, a lei de direção e de seu movimento, o princípio da 'vocação' que as orienta em direção a tal instituição ou a qual disciplina" (Bourdieu, 2011, RP, p. 43), em nosso caso, na escolha de um curso que lhe franquie a entrada no ensino superior.

Ter uma formação em nível superior, mesmo em curso desprestigiado, representa um ganho de capitais simbólico, cultural e mesmo econômico. Esse senso do jogo que estes estudantes demonstram ter deixa claro que as estratégias por eles utilizadas como forma de acumular o capital social e cultural podem ser revertidas, ainda, em capital econômico, já que ter curso superior reverte em prêmio educacional com impactos na taxa de empregabilidade e ganhos salariais de cerca de 284,10\% acima de quem tem apenas o nível médio como formação (Neri, 2009; Tinto, 2004).

A professora E7 faz uma análise interessante sobre estudantes que tinham como primeira opção outro curso e buscam se apropriar da pedagogia procurando outras possibilidades de atuação profissional. Para ela,

\begin{abstract}
é muito comum um aluno do primeiro período querer se apropriar da pedagogia pra outra coisa, por isso que eu acho que a pedagogia empresarial aparece com tanta força, agora a pedagogia ambiental... É sempre uma maneira de utilizar a pedagogia pra sair da pedagogia ou sair do campo da educação é sempre essa mecânica que ele tenta operar. Então, é isso que eu percebo no primeiro período um aluno que não está necessariamente interessado na pedagogia, mas ele quer um curso se graduação, ele quer uma faculdade. Mas eu percebo também que quando eu encontro esse aluno lá na frente, porque já passei por essa experiência várias vezes, muitos deles já estão capturados pela pedagogia. 'Eu me apaixonei pela pedagogia, eu não quero sair daqui.' É claro que eu me encontro somente com aqueles que ficaram, os que foram embora eu não tenho como encontrar. [P7]
\end{abstract}

Nossos dados indicam que 4,6\% dos respondentes pretendem atuar somente em áreas fora da pedagogia, conforme observamos na tabela 12, do que podemos deduzir que estes não consideram a possibilidade da atuação profissional como 
professores para seu projeto de vida, ou mesmo na área da educação. Tais resultados são bem próximos daqueles encontrados por Gatti (2008), em nível nacional, onde cerca de 4,8\% dos estudantes de pedagogia afirmaram "não querer ser professor". Por outro lado, muitos se abrem às duas possibilidades, $22,8 \%$ no ensino noturno e $17,6 \%$ do diurno.

Tabela 12 - Áreas em que nossos estudantes pretendem trabalhar

\begin{tabular}{|c|c|c|c|c|c|c|}
\hline & & & \multicolumn{3}{|c|}{ Área em pretende trabalhar } & \multirow[b]{2}{*}{ Total } \\
\hline & & & $\begin{array}{c}\text { Outras áreas DENTRO da } \\
\text { Pedagogia }\end{array}$ & $\begin{array}{c}\text { Outras áreas FORA da } \\
\text { Pedagogia. }\end{array}$ & $\begin{array}{l}\text { Outras áreas } \\
\text { DENTRO E FORA } \\
\text { da Pedagogia. }\end{array}$ & \\
\hline \multirow{2}{*}{\multicolumn{2}{|c|}{ Diurno }} & $n$ & 58 & 3 & 13 & 74 \\
\hline & & $\%$ & $78.4 \%$ & $4.1 \%$ & $17.6 \%$ & $100.0 \%$ \\
\hline \multirow{2}{*}{\multicolumn{2}{|c|}{ Noturno }} & $n$ & 89 & 6 & 28 & 123 \\
\hline & & $\%$ & $72.4 \%$ & $4.9 \%$ & $22.8 \%$ & $100.0 \%$ \\
\hline \multirow{2}{*}{\multicolumn{2}{|c|}{ Total }} & $n$ & 147 & 9 & 41 & 197 \\
\hline & & $\%$ & $74.6 \%$ & $4.6 \%$ & $20.8 \%$ & $100.0 \%$ \\
\hline
\end{tabular}

Fonte: Questionário SOCED / Pesquisa: Cursos de pedagogia - estudos de caso e desafios à produção de qualidade do ensino fundamental.

Nossos estudantes, ao vislumbrarem outras possibilidades dentro da formação por eles vivenciada, parecem realizar "estratégias de reconversão" (Bourdieu, 2011, p. 105) de sua escolha profissional, que se apresenta como desvalorizada, numa tentativa de se enquadrar em outras possíveis áreas de atuação mais vantajosas, não apenas financeiramente, mas que lhes apresentem uma maior valorização de seu trabalho.

Quando perguntados de modo mais geral sobre as áreas em que pretendem atuar, incluindo alguns campos mais específicos da educação, identificamos que nossos estudantes transitam entre os diferentes domínios da pedagogia, como verificado na tabela 13. Bourdieu (1968, p. 71) ao tratar das condutas simbólicas estudantis, enfatiza que o aluno possui um "querer ser e querer escolher-se". Entendemos que nossos estudantes demonstram certa negação para assumir a profissão de professor, profissão esta considerada complexa e que abarca baixa valorização social (Gatti, 2009). Essa negação está expressa em seu desejo de se 
apropriar da pedagogia para outras áreas, buscando outras formas de se afirmar naquele ambiente acadêmico, por vezes hostil: "vou seguir carreira acadêmica"; "vou trabalhar em empresas"; "vou realizar concurso para qualquer área". A opção da docência, cujo status profissional não favorece sua escolha, faz com que se valorize o "estar na universidade" em detrimento de seu curso de formação. ${ }^{4}$

Tabela 13 - Áreas em que nossos estudantes pretendem trabalhar dentro da educação

\begin{tabular}{|c|c|c|c|c|c|c|}
\hline & & \multicolumn{4}{|c|}{ Área em pretende trabalhar } & \multirow[b]{2}{*}{ Total } \\
\hline & & Educação Infantil & $\begin{array}{c}\begin{array}{l}\text { Primeiro segmento do ensino } \\
\text { fundamental }\end{array} \\
\left.\qquad 5^{\circ} \mathrm{ano}\right)\end{array}$ & $\begin{array}{c}\text { Outras áreas dentro } \\
\text { da Pedagogia }\end{array}$ & $\begin{array}{c}\text { Outras áreas fora da } \\
\text { Pedagogia }\end{array}$ & \\
\hline \multirow[t]{2}{*}{ Diurno } & $n$ & 54 & 33 & 71 & 15 & 173 \\
\hline & $\%$ & $31.2 \%$ & $19.1 \%$ & $41.0 \%$ & $8.7 \%$ & \\
\hline \multirow[t]{2}{*}{ Noturno } & $\mathrm{n}$ & 73 & 49 & 115 & 35 & 272 \\
\hline & $\%$ & $26.8 \%$ & $18.0 \%$ & $42.3 \%$ & $12.9 \%$ & \\
\hline Total & $\mathrm{n}$ & 127 & 82 & 186 & 50 & 445 \\
\hline
\end{tabular}

Fonte: Questionário SOCED / Pesquisa: Cursos de pedagogia - estudos de caso e desafios à produção de qualidade do ensino fundamental.

Percebemos que poucos futuros docentes afirmam querer atuar nos anos iniciais do ensino fundamental. O campo da educação infantil desponta como uma possibilidade de atuação profissional para cerca de um terço entre os estudantes do diurno e pouco mais de um quarto entre os que estudam à noite. Mais uma vez, o desejo de trabalhar em outras áreas, fora da pedagogia, também aparece mais forte entre os estudantes do curso noturno. No geral, nossos estudantes desejam uma ocupação na área da educação, mas fora da sala de aula.

A grande maioria pretende, portanto, atuar profissionalmente no campo da pedagogia, corroborando as falas dos professores de que no decorrer do curso

\footnotetext{
${ }^{4}$ De modo semelhante, observamos, durante discussões do SOCED, que o estudante das universidades norte-americanas normalmente enfatiza sua formação em uma instituição universitária e não em cursos específicos. Basta acompanhar os sites destas instituições para observar o forte "pertencimento" que seu alunato demonstra ter pela sua universidade de formação, contribuindo inclusive com doações financeiras após a formatura. Além disso, uma professora da PUC-Rio relata verificar este fator em estudantes de intercâmbio com os quais mantém contato.
} 
esses alunos são "capturados" pela pedagogia, ou, nos seus termos, "criados", para se voltarem à àrea de educação. Dentre as áreas de maior destaque dentro da pedagogia, conforme tabela 14, está a administração / gestão escolar, que engloba funções como coordenação, orientação educacional, supervisão escolar; 21,7\% entre aqueles que estudam à noite e outros $13,2 \%$ dos que estudam pela manhã pretendem atuar nessa área na escola. Porém, parece-nos problemático, a partir do ponto de vista do ensino, o fato de este aluno querer ser um gestor dos processos escolares sem nunca ter passado pela função de professor.

Percebemos ainda que especialmente áreas do currículo do curso, como educação especial, educação de jovens e adultos e movimentos sociais, aparecem como campos pretendidos de atuação, apesar de terem menor força. Geralmente, os estudantes participam de grupos de pesquisa na área, como no caso de educação hospitalar, que embora se trate de tema bastante específico na área de educação, aparece como opção profissional de alguns.

\section{Tabela 14 - Subáreas em que pretende trabalhar dentro da pedagogia}

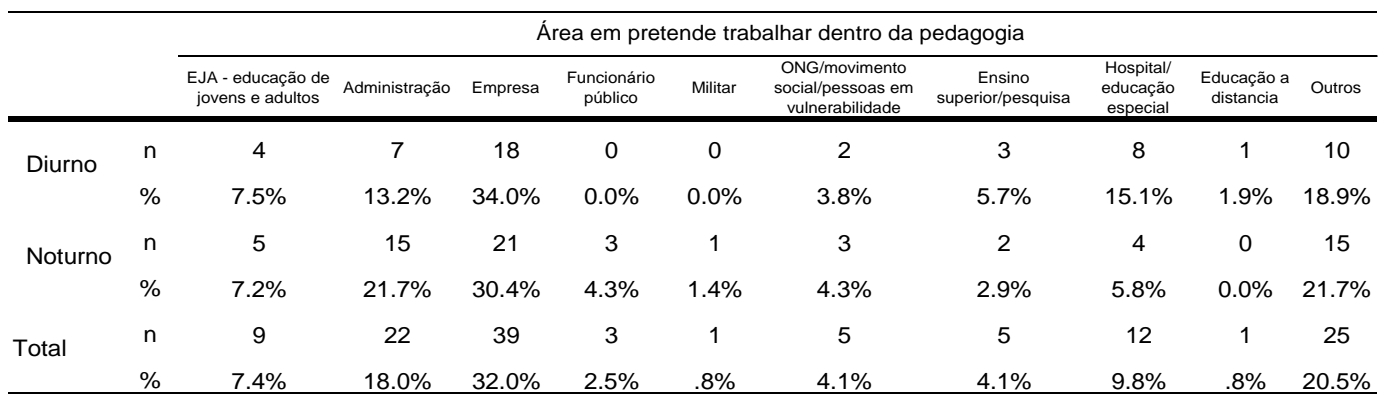

Fonte: Questionário SOCED / Pesquisa: Cursos de pedagogia - estudos de caso e desafios à produção de qualidade do ensino fundamental.

Entre os relatos dos estudantes, há quem escolheu o curso, por exemplo, "por conhecer a pedagogia empresarial e saber que poderia trabalhar com recursos humanos". Uma aluna relata:

$\mathrm{Na}$ época do vestibular eu já sabia que queria atuar com RH. Tinha três opções, administração, psicologia ou pedagogia. Administração tem cálculo que eu não iria me dar bem; psicologia tem anatomia e eu não consigo ver sangue. Então, a única opção que restou foi pedagogia. [R33, estudante do noturno originalmente da manhã] 
A pedagogia empresarial e recursos humanos aparecem tanto nas áreas dentro da pedagogia como em áreas fora da pedagogia. Isso sugere que para alguns, estas atividades não são consideradas pedagógicas. Realmente, este não é o foco do curso de pedagogia da UERJ, apesar de sua habilitação deixar claro que o egresso do curso será capaz de atuar em demais espaços em que se exija um profissional para gerir processos educacionais.

\section{Tabela 15 -Áreas em que se pretende trabalhar fora da pedagogia}

\begin{tabular}{|c|c|c|c|c|c|c|}
\hline & & \multicolumn{4}{|c|}{ Área em pretende trabalhar } & \multirow{2}{*}{ Total } \\
\hline & & Concurso público & Empresa/RH & Militar & Outros & \\
\hline \multirow[t]{2}{*}{ Diurno } & $\mathrm{n}$ & 2 & 4 & 1 & 9 & 16 \\
\hline & $\%$ & $12.5 \%$ & $25.0 \%$ & $6.3 \%$ & $56.3 \%$ & $100.0 \%$ \\
\hline \multirow[t]{2}{*}{ Noturno } & $n$ & 3 & 17 & 1 & 11 & 32 \\
\hline & $\%$ & $9.4 \%$ & $53.1 \%$ & $3.1 \%$ & $34.4 \%$ & $100.0 \%$ \\
\hline \multirow[t]{2}{*}{ Total } & $\mathrm{n}$ & 5 & 21 & 2 & 20 & 48 \\
\hline & $\%$ & $10.4 \%$ & $43.8 \%$ & $4.2 \%$ & $41.7 \%$ & $100.0 \%$ \\
\hline
\end{tabular}

Fonte: Questionário SOCED / Pesquisa: Cursos de pedagogia - estudos de caso e desafios à produção de qualidade do ensino fundamental.

Aqueles que escolheram o curso, por querer o título do ensino superior, normalmente são os que pretendem realizar concursos públicos para quaisquer áreas, militares, ou mesmo aqueles que pretendem realizar outras atividades profissionais, conforme observamos na tabela 15 . Um dos respondentes, no campo aberto para acrescentar qual área pretende trabalhar, ele respondeu "em uma função estável, primeiro eu tentaria concurso para áreas da pedagogia, depois para qualquer área". A opção pelo curso para se obter o diploma no ensino superior, o que habilitaria muitos à realização de concursos públicos, aparece entre os dois turnos com 34,9\%. A realização do curso como outra opção profissional que não a área de educação também tem um resultado expressivo, especialmente entre os estudantes do noturno, $26,6 \%$, já entre os alunos do diurno, 17,6\%. Gatti e Nunes (2008) ressaltam que nestes casos, pedagogia parece ser uma espécie de "seguro desemprego".

Percebemos ainda que o percentual de estudantes que mudariam de curso é bem próximo do número daqueles que desejam trabalhar em outras áreas da 
pedagogia. Entre os alunos do curso noturno, 27,4\% mudariam de curso, entre os que estudam pela manhã, $22,3 \%$ o fariam. $O$ fato de que apenas cerca de um quarto dos estudantes afirmarem que mudariam de curso pode estar ligado ao fato de que nossos entrevistados já cursaram metade do curso. Geralmente, a decisão de mudar de curso é tomada no primeiro ano do curso (Coulon, 2008; Costa \& Lopes, 2007). Os estudantes em questão, apesar de alguma insatisfação, já decidiram permanecer no curso, e pretendem futuramente, realizar outra graduação em outra área, como observamos em seus relatos: "Queria fazer direito na UERJ e ainda continua sendo meu sonho, porém deixarei mais para o futuro porque pretendo concluir pedagogia" (R53, quinto período, noturno). "Meu desejo, na verdade, é realizar pós-graduação em psicopedagogia e, mais tarde, buscar graduação em psicologia” (R7, sexto período, noturno).

Uma possível razão para essa insistência em entrar para o ensino superior, independentemente do curso, pode ser pelo desejo de uma vida melhor, como vemos nos estudos de Charlot (2005, p. 67), segundo os quais “de 75 a $80 \%$ dos alunos estudam para mais tarde ter um emprego melhor”. Seguindo sua lógica, para se conseguir um bom emprego, é preciso ter diploma, e, para isso, é preciso ingressar no ensino superior, e ainda, é preciso "passar" nas disciplinas, e no caso da instituição pesquisada, escrever uma monografia. Vargas e Costa de Paula (2013), a partir de levantamento de dados de 2004 do MEC e INEP, apontam que a grande maioria dos concluintes do ensino superior, $80 \%$, consideram que a principal contribuição do curso foi a aquisição de formação profissional, ou seja, qualificação para atuação profissional. Tais estudantes, como vemos, já vislumbram sua inserção no mercado de trabalho.

Para Charlot, o jovem de classe popular possui como projeto de vida ter condições financeiras de se sustentar de modo legítimo socialmente. Ele sabe, pois, que precisa da instituição escolar para conseguir os melhores empregos. Como lemos em Neri (2009), mais anos de escolarização representam a possibilidade de maior empregabilidade, bem como ganhos salariais. $\mathrm{O}$ curso de pedagogia desponta como este caminho, especialmente pela abertura que o diploma de nível superior proporciona para o exercício de futuras atividades profissionais. 
Através do relato de uma de nossas estudantes, ao reclamar da pouca participação de suas colegas e falta de interesse pelo curso, ela parece ter esta percepção bastante clara. "Acredito que a falta de interesse se dê porque a maioria das pessoas que cursa pedagogia não vê o trilhar das matérias como uma experiência de aprendizagem, e sim como mais uma disciplina a cumprir no currículo para se chegar ao diploma" [R50, sétimo período, diurno]. Esse tipo de relação com o conhecimento, apenas para cumprir mais uma disciplina, para ter um emprego melhor, ou outras opções profissionais no futuro, é uma apropriação frágil do saber (Charlot, 2005, p. 64) e, segundo este autor, "surte quase nenhum efeito na formação".

Por outro lado, entendemos que a fala expressa nos relatos de professores e estudantes sobre o fato de o curso de pedagogia cooptar esses estudantes, ou mesmo, quando estes estudantes mencionam que se "apaixonaram" pelo curso, pode significar que eles são conduzidos a "ter gosto daquilo a que, de qualquer modo, estão condenados" (Bourdieu, 2011, p. 169). Na leitura de Bourdieu, gosto é "amor fati, escolha do destino embora forçada, produzida por condições de existência que, ao excluir qualquer outra possibilidade como se tratasse de puro devaneio, deixam como única escolha o gosto pelo necessário" (idem).

A necessidade impõe um gosto por necessidade que implica uma forma de adaptação à necessidade e, por conseguinte, de aceitação do necessário, de resignação ao inevitável, disposição profunda que não é, de forma alguma, incompatível com uma intenção revolucionária. (Bourdieu, 2011, p. 350)

Vemos que "o gosto como necessidade tornada virtude" faz com que nossos estudantes decidam por permanecer no curso de pedagogia, afinal, já houve um grande investimento e exigiria-se mais tempo para reiniciar uma nova formação no ensino superior, o que acarretaria postergar a sua vida profissional. A opção de concluir este curso e, em futuro próximo, reingressar em nova formação universitária (em qualquer instituição de ensino superior sem a necessidade de realização de novo vestibular e sim de uma prova específica da área) pode parecer como mais viável para quem precisa, na maioria dos casos, trabalhar para estudar. Mais uma vez, a permanência no curso de pedagogia aparece como a "estratégia mais razoável". A conclusão do curso superior pode acarretar de imediato o aumento de capital simbólico e social na vida destes estudantes. 


\section{2}

\section{Infraestrutura da universidade}

Durante minhas observações na instituição analisada, avistei um grande número de estudantes que ficam no hall do andar. Ali é ponto de encontro e de espera entre uma aula e outra, sendo também o lugar para se "dar uma olhada" no texto da aula seguinte. Este dar uma olhada não é muito mais que 10 minutos e ainda, é cheio de interrupções. Chega um colega perguntando alguma coisa sobre alguma aula, o aluno vai buscar um lanche; ele fala ao celular, tira um cochilo e volta às primeiras páginas do texto em questão. Como um dos professores entrevistados comenta, "a universidade não propicia isso [prática de estudo], não sei se outras propiciam, mas é difícil vê-los na biblioteca ou se encontrar aqui em um lugar para estudar, eu não vejo os alunos fazendo isso". [P16]

Os professores citaram a própria estrutura física da UERJ como um problema para a promoção de práticas de estudo e permanência do estudante na universidade. O professor [P16] ressalta que percebe que os estudantes não se sentem acolhidos pela universidade, "aqui os alunos vêm, sobretudo para cursar as disciplinas e vão embora. Esta é uma cidade que demora muito para voltar para casa, e todos estão um pouco apressados". Isso, por exemplo, é mais difícil de se perceber entre alunos da PUC-Rio ou da UFRJ. Nestas instituições, o aluno frequenta os mais diferentes espaços da universidade, sentam pelo campus, estudam ao ar livre. A estrutura física da UERJ em um único prédio, "sem verde" algum, como colocado por vários professores, joga contra a possibilidade de a universidade ser um espaço acolhedor para se estudar, realizar debates e conversar. Durante as entrevistas com a equipe gestora do curso, três professores mencionaram as tentativas de tornarem o espaço mais bonito, colocando flores nos corredores, e instalando placas informativas por toda a faculdade.

Em um dos relatos que nos foi enviado, a aluna desabafa sobre a precariedade da infraestrutura oferecida pela instituição: "fico indignada com a estrutura das salas de aula, com mesas de professor e cadeiras quebradas, salas sem ar condicionado... visto que se trata de uma universidade do Estado, deveria no mínimo ter boa estrutura" [R11, sétimo período, noturno]. 
Enquanto aluna da universidade, eu vivenciei as dificuldades de permanência na instituição. Por mais tentativas que se realizasse para mudar este quadro, o ambiente não proporcionava qualquer tipo de conforto para os estudos. A sala de estudos da biblioteca, bem como todo o seu espaço de consulta aos livros, não era refrigerada, o que causava um desconforto enorme, já que estava ali o dia todo, com aula pela manhã e à noite (na ocasião, cursava neste período disciplinas que tive de adiar ao longo do curso, devido à pesada rotina que vivenciava de cursar duas faculdades e ainda realizar estágio), queria utilizar o período da tarde para estudos, o que era muito custoso.

A professora com quem trabalhei durante quase três anos da graduação, como bolsista de extensão e de iniciação científica, por exemplo, possui um escritório em sua casa na Gávea, no qual seus bolsistas, em número sempre próximo de dez, se revezavam nos trabalhos durante a semana. As dificuldades encontradas ao ter de sair da UERJ e ir para a Zona Sul realizar estágio em pesquisa e depois voltar para casa (a maioria morava na Zona Norte), fazia com que o trabalho se tornasse desgastante para todos nós. Contudo, a infraestrutura de trabalho oferecida pela professora, com uma biblioteca específica e atualizada sobre os temas de estudo, computadores, impressoras e demais recursos tecnológicos que precisássemos, bem como refrigeração e o "chá das cinco" (organizado pelos bolsistas sempre com alguma contribuição da professora), fazia com que valesse a pena, pois tínhamos um agradável ambiente fomentador de pesquisa, o que resulta no fato de que a maioria dos estudantes que por ali passa continuar seus estudos na área.

Atualmente na UERJ há um movimento de os professores criarem laboratórios para seus grupos de estudo, utilizando, por vezes, o que antes era sala de aula da universidade. Há várias salas ambientadas de acordo com as temáticas de estudo, como por exemplo, de educação infantil, de história da educação, de educação especial, entre outros. Nestas salas, podem ocorrer aulas da grade curricular da graduação em pedagogia, no entanto, ficam restritas aos departamentos, e, às vezes, a algumas disciplinas de alguns professores do grupo. Como seu uso não é franqueado a todos os professores, especialmente os professores substitutos se sentem prejudicados e reclamam de uma distribuição 
desigual dos espaços e recursos da universidade. Segundo nosso entrevistado nesta condição, as

salas que estão equipadas hoje com os recursos audiovisuais não ficam na mão dos substitutos. Claro que hoje têm mais salas equipadas do que antes. [...] Inclusive uma vez foi falado assim: 'Mas você é substituto e está nesta sala. Essa sala tem computador, tem telão, tem tela de projeção, e não-sei-o-quê mais’ [P10].

Nestes laboratórios, além das aulas, acontecem também as reuniões dos respectivos grupos de pesquisa e é franqueado aos bolsistas o acesso ao espaço em determinados horários, o que permite a estes poucos estudantes ter um ambiente mais favorável aos seus estudos.

O laboratório de informática, que foi inclusive criado na época em que lá estudei, também tinha vários problemas de manutenção, ficando sem funcionar, por dias, semanas e até meses, dependendo dos problemas ali enfrentados. Durante minhas visitas, percebi que o laboratório de informática do andar não funcionou um só dia, com a seguinte informação colada na porta "em manutenção". Entendo que o estudante pode acessar os laboratórios de outros andares, ou mesmo o geral da UERJ, que fica no térreo, porém, acredito que o deslocamento será um fator de dificuldade maior para este estudante, que vai assistir à aula e sai apressadamente para suas demais atividades. Eu mesma, enquanto estudante, nunca utilizei outros laboratórios da universidade, mesmo sabendo de sua existência.

Hoje a biblioteca está toda climatizada e com novos mobiliários, resultado da parceria com a Faculdade de Educação, que, segundo a funcionária da biblioteca com quem conversamos, é uma grande parceira da biblioteca, promovendo a melhoria tanto da estrutura física do espaço como do acervo, através de vários projetos individuais dos professores. Recentemente, através de uma destas parcerias, foram adquiridos nove notebooks para uso dos estudantes na biblioteca por uma hora, podendo ser prorrogado pelo mesmo período. A procura é grande segundo nossa entrevistada. Os estudantes que frequentam o espaço possuem, portanto, mais uma ferramenta para realizar suas pesquisas e digitarem seus trabalhos. 
A sala de estudo hoje conta com refrigeração, novos mobiliários, divisão do espaço de estudo e tomadas para uso de computadores pessoais pelo estudante. Apesar de a iluminação ainda ser problema, pois à tarde o sol bate diretamente no andar e as novas persianas e refrigeração ainda não deram conta de manter o ambiente agradável, já houve uma grande melhoria do espaço.

A sala de consulta também foi totalmente reformulada. Atualmente, o aluno que queira estudar na biblioteca encontra esses novos espaços, mas há pouca procura por estes recursos. Com o espaço reformulado, deveria haver um movimento na faculdade de orientar os estudantes sobre o lugar do estudo na formação acadêmica, buscando criar assim, o hábito entre os estudantes. Nossa informante contou que há uma procura pela biblioteca especialmente para a retirada de livros e para a realização de trabalhos. Nossa entrevistada traçou marcadamente o perfil dos estudantes do diurno e noturno. Para ela, os estudantes do diurno realizam suas visitas à biblioteca mais calmamente, eles passam mais tempo lá, ficam depois da aula utilizando o espaço para estudo e realização dos trabalhos individuais e em grupo. Já os alunos da noite "querem tudo muito rápido", ela informou. Eles chegam retiram o livro que precisam e voltam para a aula. Há uma maior procura da biblioteca pelos estudantes de pedagogia do curso noturno, porém, segundo nossa informante, há maior rotatividade entre os estudantes. O período mais cheio é de 17 h30 até 19h30, exatamente o período em que os estudantes da noite chegam para a aula, mas sendo eles de maioria trabalhadora, não possuem o tempo necessário para aproveitar o espaço.

Tais recursos deveriam ser fornecidos pela universidade, no entanto, muitas reformas realizadas pela Faculdade de Educação são frutos da sua parceria com seus professores e resultado de anos de reivindicação dos alunos. Alguns problemas levam anos para serem solucionados, pois além da demora na aquisição dos recursos necessários, os agentes ainda não adquiriram as disposições (habitus) necessárias para a utilização dos novos recursos, como no caso dos materiais disponíveis na biblioteca. Segundo um de nossos entrevistados, que estudou na instituição na década de 90,

as goteiras que nós tínhamos aqui no $12^{\circ}$ andar foram resolvidas há uns quatro anos, por aí. Mas as reivindicações pra acabar com as goteiras são do meu tempo 
de aluno. Pra você ter uma ideia o bandejão que eu acho importante, mas que eu já não dou tanta importância como eu dava naquele tempo, também era reivindicação do meu tempo que foi atendida agora. Mas, sobre as condições particulares da Faculdade de Educação, elas, na verdade, do meu ponto de vista, têm melhorado nos últimos tempos, ainda que em passos lentos [P11].

Estas condições físicas da universidade realmente ainda não favorecem para que o estudante permaneça na instituição para estudo. Provavelmente, este seja o motivo pelo qual o ambiente mais utilizado para estudo por $78 \%$ de nossos estudantes seja a sua residência. Em segundo lugar, aparece o transporte público (metrô, ônibus, trem) com 29,6\%, e em terceiro, com 17,9\% das respostas, o local de trabalho. Vale destacar que $12,9 \%$ dos estudantes costumam "estudar" prioritariamente em locais públicos, como por exemplo, o hall da universidade.

Esse último aspecto demonstra a subutilização dos espaços da universidade para estudo, indicando a falta de costume em ficar na universidade. O tempo que o estudante fica no hall ou nas mesas da cantina lendo algum material enquanto aguarda o início da aula poderia ser revertido em tempo para estudo na sala destinada a este fim na biblioteca, por exemplo, onde sequer é necessário guardar o material para entrar, o que poderia significar, para alguns, perda de tempo.

Outra questão é quanto à distribuição de recursos entre os turnos. Em uma turma do curso noturno em que aplicamos o questionário, no momento da explicação sobre o propósito de nosso estudo, uma estudante pediu a palavra e disse que era preciso realizar tal estudo, pois o tratamento com relação ao curso noturno era diferenciado. Outra estudante descreve bem esta situação: “infelizmente grande parte das disciplinas [eletivas], recursos e professores se concentram no turno da manhã, o que faz declinar a qualidade do curso noturno e as chances dos alunos terminarem no tempo certo" [R30, estudante do noturno, originária do diurno].

Este sentimento é bastante comum entre os estudantes do curso noturno. Eles comentam que as palestras e eventos são sempre realizados no diurno. No entanto, pude vivenciar uma situação um tanto contraditória em relação a esta afirmação. Na semana de educação, realizada pela Faculdade de Educação, apesar de haver um público médio nas palestras da noite, era visível que muito menos que metade dos estudantes do noturno compareceu. Outros saiam aos poucos, até 
que ao final, o auditório estava bastante esvaziado, mesmo sendo dentro do horário normal de aula do curso noturno. Conversei com alguns alunos que saíram e eles comentaram que estavam muito cansados para ouvir a palestra, e ainda outra afirmou que não podia ficar mais por causa do horário do transporte.

A questão da distribuição de professores, efetivos e substitutos, foi assunto bastante ressaltado pelos estudantes e também destacado pelos professores entrevistados, especialmente com relação ao grande número de professores substitutos que a universidade possui. Tivemos acesso aos dados do semestre 2013.1, em que 58,5\% do corpo docente da Faculdade de Educação eram de professores na situação de contrato com a universidade, ou seja, professores substitutos.

Quem dá aula à noite normalmente é professor que não atua na pós, não trabalha durante o dia na pós-graduação. À noite a grande maioria são professores contratados, substitutos, porque de manhã a gente dá conta, quem trabalha na pósgraduação, mestrado, doutorado, tem você mesmo ou nossos alunos [de mestrado e doutorado que realizam estágio de docência]. De manhã todas as turmas são atendidas por nós, de noite não. Então você tem uma quantidade enorme de turmas de professores substitutos, que são transitórios. [P14]

Tal problema, no entanto, não é recente. Em pesquisa de 1988, entre os estudantes do curso, esse assunto já era destacado (UERJ, 2002). Como ouvimos dos representantes da gestão do curso, o problema é crônico, já que não há professores efetivos suficientes para atender ao curso de pedagogia, bem como todas as disciplinas pedagógicas oferecidas em todas as licenciaturas.

A situação se agrava pelo fato de que a maioria dos professores efetivos, especialmente os que atuam na pós-graduação, leciona no turno da manhã. Como somente professores efetivos podem orientar monografia de conclusão de curso, muitos estudantes do noturno não conseguem orientação, ou possuem dificuldade em conciliar seu horário com o do professor efetivo. Como a aluna acima menciona, esta situação acaba atrasando o término do curso. Fica evidente, nestes casos, a distribuição desigual de recursos entre os turnos.

Eles não acham orientador, por exemplo, os professores substitutos não podem orientar monografia. Então, o aluno do curso noturno tem que procurar um 
professor pra orientá-lo que ele não conhece, que ele não conviveu com ele. Não foi professor dele. Então ele passa primeiro, segundo, terceiro, quarto, quinto período, sexto período com professores substitutos que não podem ser seus orientadores e eles precisam procurar orientadores em outro horário. É uma faculdade que ele não conhece, tem o professor que está lá [no mural de orientadores], mas ele não dá aula, é o doutorando dele que deu ao realizar estágio de docência. [P1]

\subsection{1}

\section{A Faculdade de Educação e o currículo de curso de pedagogia da UERJ-Maracanã}

No documento Programa UERJ de formação de professores para a educação básica: a reformulação do curso de pedagogia da Faculdade de Educação (Faculdade de Educação - UERJ, 2002) é apresentado um breve resumo da história da UERJ e da própria Faculdade de Educação, e sobre como se deu a reelaboração da proposta curricular do curso de pedagogia da instituição.

A história da Faculdade de Educação da UERJ está ligada à criação em 1939 da Faculdade de Filosofia, Ciências e Letras do Instituto La-Fayette, que teve em 1941 a autorização para funcionar uma unidade de educação, e dentre alguns cursos, o curso de pedagogia e didática. Em 1950, o instituto foi convertido em unidade da Universidade do Distrito Federal, que à ocasião era subordinada à prefeitura da capital da república. Em 1959, esta instituição passou a ser chamada Universidade do Rio de Janeiro e, logo em seguida, com a transferência da capital do país para Brasília e criação do estado da Guanabara, em 1961, passou a ser denominada de Universidade do Estado da Guanabara (UEG). Com a criação da Faculdade de Filosofia e Educação na UEG, a unidade de educação passa a ser integrada a esta, e em 1971, torna-se parte do Centro de Educação e Humanidades. Somente em 1975, com a fusão dos estados da Guanabara e do Rio, que a UEG passa a ser denominada Universidade do Estado do Rio de Janeiro. A Faculdade de Educação é inaugurada no atual local em 1976.

A grade curricular do curso de pedagogia entre os anos de 1976 e 1991 oferecia seis habilitações, com a possibilidade de o estudante escolher uma delas 
para se especializar. Eram elas supervisão escolar, orientação educacional, administração escolar, educação do deficiente mental, educação do deficiente auditivo e magistério das matérias pedagógicas. A estrutura do curricular definia oito períodos, sendo que os quatro primeiros fossem de disciplinas comuns a todas as habilitações e os demais na habilitação escolhida pelo estudante. A partir de 1988 houve um movimento de discussão para a reformulação do curso, que parecia insatisfatório para todos.

Em 1991, após três anos de discussões, um novo curso foi criado, com uma configuração de seis semestres de base comum e os dois períodos finais de dedicação a uma das quatro habilitações oferecidas: educação infantil; educação de jovens e adultos; educação especial e magistério das matérias pedagógicas.

Paralelo às discussões para elaboração de tal curso, a UERJ e a Prefeitura da Cidade do Rio de Janeiro, através da Secretaria Municipal de Educação, firmaram um convênio para formação inicial e continuada de professores, através de cursos de extensão e um curso de graduação de licenciatura plena de magistério das séries iniciais do $1^{\circ}$ grau (CPM). A proposta deste curso foi considerada inédita no Brasil por formar professores e envolver tanto os professores da SME, como os da UERJ e do CAP/UERJ. Tal convênio durou de 1991 a 1995. A partir de então, a UERJ abriu o curso para a comunidade em geral, e ficou, portanto, com dois cursos em funcionamento, com propostas curriculares diferentes.

A última grande reforma curricular do curso de pedagogia da UERJ, em 2002, originou-se das discussões do Programa UERJ de formação de professores para a educação básica, iniciadas em 1997 e regulamentadas em 2001. Naquele momento, a concepção de curso que ganhou força foi a formação conjunta entre licenciatura e bacharelado, integrando os dois cursos PED e CPM em um só, formando o professor, mas também o pedagogo.

Entendemos que o curso da UERJ foi se reelaborando em consonância com as diretrizes nacionais para o curso de pedagogia no Brasil. No documento acima citado, onde é apresentado o processo de construção curricular do curso, bem como de sua concepção, está clara tal influência em sua proposta, em especial as discussões da ANFOE e FORUNDIR. Segundo tal documento, a proposta preliminar para diretrizes curriculares para o curso de pedagogia (Portaria 
$\mathrm{SESu} / \mathrm{MEC} \mathrm{n}^{\circ}$ 172/96) teve papel fundamental na definição dos eixos do curso, pois define o papel do pedagogo, como

profissional capacitado para atuar em atividades científico-tecnológicas do campo educacional, em especial:

- na educação infantil, nas séries iniciais do ensino fundamental e nos conteúdos pedagógicos da formação docente;

- na organização e gestão de sistemas, unidades e experiências educacionais escolares e não escolares;

- na produção e difusão do conhecimento científico e tecnológico do campo educacional.

A proposta curricular do curso buscou assegurar, portanto, o perfil do pedagogo como "professor, organizador e gestor do sistema educacional e pesquisador" (Faculdade de Educação - UERJ, 2002). Para tanto, procuraram estabelecer "conteúdos curriculares que darão conta da formação ampla e consistente de um pedagogo-professor" (idem), incluindo também princípios da educação inclusiva. Assim, o curso oferece no bacharelado o foco nas instituições e nos movimentos sociais, enquanto que a licenciatura oferece formação para professores para a educação infantil, anos iniciais do ensino fundamental para crianças e jovens e adultos. A formação para a licenciatura é, segundo o documento citado, embasada na classificação internacional Eurostar / Unesco / OCDE.

Através da leitura dos objetivos do curso, percebemos a amplitude de sua proposta, bem como a ênfase na prática de pesquisa e tentativa de articular a docência com a formação do pedagogo e professor para atuar na educação infantil, ensino fundamental para crianças, jovens e adultos, e em espaços não escolares, tais como empresas e demais instituições. Os objetivos do curso são assim expostos:

- propiciar formação de professores para os anos iniciais do ensino fundamental para crianças, jovens e adultos, coerente com a realidade sócio-político-cultural da escola brasileira na perspectiva da inclusão dos alunos portadores de necessidades educativas especiais.

- capacitar os alunos para a atuação em atividades específicas de educação infantil de zero a seis anos em organizações governamentais ou comunitárias, incluindo 
programas de estimulação para bebês e crianças portadoras de necessidades educativas especiais.

- desenvolver atividades de docência, pesquisa e extensão que permitam aos alunos se apropriarem de conhecimentos e habilidades que propiciem a inter e a transdisciplinaridade.

- organizar e desenvolver projetos e experiências pedagógicas que promovam oportunidades de pesquisa coletiva a todos os participantes do programa.

- preparar o futuro pedagogo para atuar em espaços não escolares, tais como empresas, conselhos, instituições governamentais e movimentos sociais, tendo como elemento norteador o eixo ação-reflexão-ação.

- propiciar a constante troca de experiências entre a universidade e as diversas comunidades existentes. (UERJ, 2002, p. 24)

A proposta do curso pretende formar um "pedagogo-professor" capaz de elaborar, avaliar e desenvolver projetos; consciente da necessidade de se atualizar através de leituras, cursos, seminários, entre outros; ter claro seu papel político na sociedade; possuir fundamentação teórico-prática dos conhecimentos a serem ministrados; assumir funções de gestão/coordenação, planejamento e avaliação em instituições e movimentos sociais.

Toda modificação curricular é política e, como observamos na fala de um de nossos entrevistados, esse processo de junção entre os dois cursos da área de educação da UERJ, o PED e o CPM, não foi um processo simples e consensual.

Quando começou a discussão sobre o novo perfil do licenciado em pedagogia começou o problema, porque a ideia era, então, fazer com que o CPM e a pedagogia regular se fundissem em um só curso, certo? Eu achei a ideia ótima, só que eu não percebia o que acontecia. Na verdade, o que aconteceu foi uma tentativa de engolir no discurso da pedagogia regular, o discurso da formação do professor, porque o CPM era um incômodo, ele era um incômodo porque primeiro fazia as pessoas terem que sair do seu lugar de conforto e dialogar com a escola, isso já era o fundamental, em segundo lugar ele era um incômodo porque ele obrigava o campo da educação a se tornar professor, e foi aí que eu fui ter a clareza de que no campo, na área da educação existe uma refração enorme com relação à licenciatura, entendeu? Formar o professor é tudo que o pedagogo não quer, eu não sei por que, mas existe um racha interno. [P16]

Parece que para atender às diretrizes curriculares do curso de pedagogia, que estabelecia a formação para a docência como primordial, e com o desejo de manter as características do curso PED cujo enfoque era a formação do pedagogo, 
por meio das habilitações, surge o entendimento do pedagogo-professor, com marcante interesse na atuação do pedagogo.

Para alcançar esta proposta, segundo o documento, buscou-se uma organização em que apesar da nomenclatura "disciplina", tivesse uma lógica de “campos organizadores do conhecimento, que tem a ver com a história concreta da Faculdade de Educação, tanto com o seu passado vivido, como com um futuro exigido" (UERJ, 2002, p. 26).

O gráfico 4 permite verificar que há uma distribuição bastante igualitária entre os três eixos do curso proposto, a educação infantil, os anos iniciais para crianças e jovens e adultos e o bacharelado, formação para atuação nas instituições e nos movimentos sociais. Entretanto, tal distribuição igualitária não parece ser sentida pelos estudantes, como veremos.

\section{Gráfico 4 - Distribuição de horas-aulas entre as áreas de conhecimento do campo pedagógico}

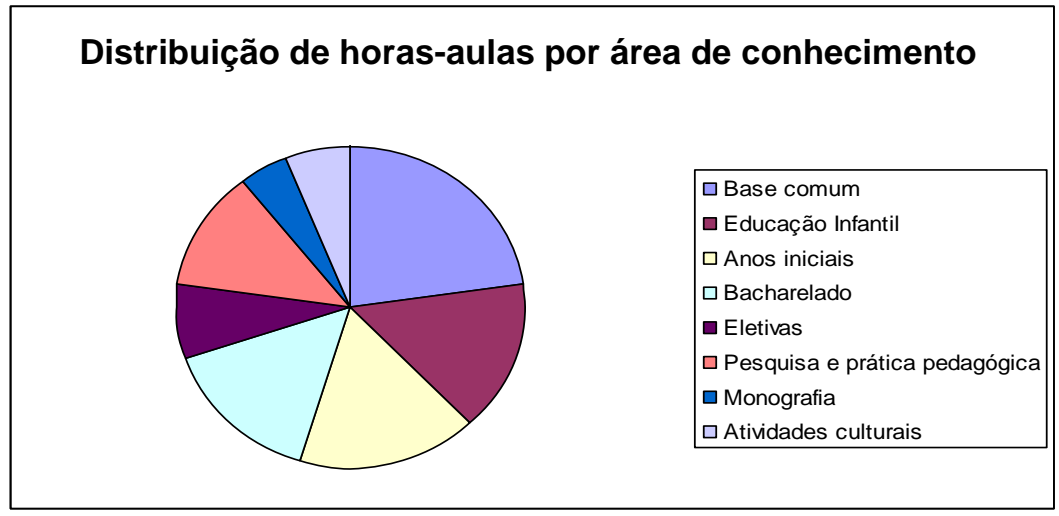

Fonte: Elaboração própria.

Como no curso há uma ênfase no componente da pesquisa como norteador do curso, a disciplina Pesquisa e Prática Pedagógica (PPP) cumpre este papel. Diluída em seis semestres, tem como proposta permitir ao estudante dedicar-se ao estudo de uma temática durante toda sua trajetória acadêmica, podendo realizar a troca de temática por uma vez ao longo do curso. A partir daí, o estudante teria suporte na elaboração da sua monografia de final de curso, que era dividida em duas disciplinas nos dois últimos períodos finais. O professor desta disciplina 
acompanha sua turma durante os três anos do curso, e é também responsável por contabilizar as complementares desenvolvidas na disciplina atividades culturais, ou seja, atividades realizadas pelos estudantes fora da sala de aula, como participação em eventos culturais e acadêmicos. Cabe ressaltar que todos os professores desta disciplina, bem como da monografia, são efetivos da universidade.

Em 2011, o curso de pedagogia passou por novas reformulações, mais uma vez, primeiramente, para atender às novas exigências das diretrizes, de formar apenas o licenciado, mas também para atender a uma nova demanda que acabava de surgir, a de formar o professor das disciplinas pedagógicas. Como vimos, com a reformulação do curso de 2001, a formação para as disciplinas pedagógicas foi deixada de lado já que a LDB previa a extinção do curso normal, considerando que todos os professores deveriam ser formados em nível superior. Quando alguns estudantes das primeiras turmas formadas por este novo currículo realizaram concurso do estado para atuar no curso normal com as disciplinas pedagógicas, muitos assumiram seus cargos e foram posteriormente exonerados, pois o currículo de pedagogia da UERJ não habilitava seus concluintes a exercer esta função.

O currículo passou por nova reformulação, entretanto, bem menos estruturais que a reformulação de 2001. A solução encontrada para a atender à formação para atuar no magistério dos cursos de ensino médio foi diminuir a carga horária dos três estágios (educação infantil, anos iniciais e instituições e movimentos sociais) e criar um novo estágio no magistério das disciplinas pedagógicas. De 120 horas-aula, cada estágio passou a ter 90 horas-aula.

Outras pequenas reformulações também foram realizadas de modo a acertar o currículo. Uma delas foi a diminuição da carga horária de PPP que, no novo currículo, passa a ter duração de dois anos e não mais três. Com a carga horária equivalente a duas disciplinas, outras duas foram criadas, uma voltada para ensino de matemática II, e a segunda permitiu o desmembramento da disciplina Ensino de História e Geografia para crianças, jovens e adultos, resultando em uma disciplina voltada ao ensino de história e outra de geografia. Uma nova disciplina foi criada, com carga horária semelhante a de uma eletiva, 30 horas, chamada Dinâmica e Práticas da Vida Universitária, ofertada no primeiro período. Os 
objetivos da disciplina são, de acordo com o ementário da UERJ, “contribuir para o desenvolvimento e adaptação acadêmica do aluno, visando à utilização mais eficiente de recursos intelectuais, psíquicos e relacionais, numa visão integrada dos aspectos emocionais e pedagógicos” (UERJ, 2014). A disciplina ainda se propõe a "orientar o aluno quanto a hábitos, técnicas e estratégias de estudo e de pesquisa individual e em grupo" além de promover a integração dos estudantes no ambiente universitário, de modo a "minimizar o insucesso e evasão fracasso escolar no curso de pedagogia" (idem). Tal disciplina tenta cumprir, talvez, o serviço que diversas universidades oferecem ao estudante como cursos que dão dicas de como estudar, de gerenciamento do tempo, de escritas de trabalhos acadêmicos, entre outros, como vemos em Lopes e (2009), serviços esses fundamentais para a promoção do sucesso escolar dos estudantes universitários.

A titulação recebida pelos alunos concluintes do curso de graduação em pedagogia da Faculdade de Educação da UERJ Campus Maracanã ficou assim definida após sua última reformulação:

Licenciado em pedagogia e poderão exercer o magistério em classes de educação infantil e dos anos iniciais do ensino fundamental para crianças, jovens e adultos, nos cursos de ensino médio na modalidade normal, de educação profissional na área de serviços e apoio escolar e em outras áreas nas quais sejam previstos conhecimentos pedagógicos, compreendendo a participação na organização e gestão de sistemas e instituições de ensino, assim como nas instituições e nos movimentos sociais.

O curso possui uma carga horária de 3890 horas, bem acima do exigido pela legislação que estabelece o mínimo de 3200 horas (BRASIL, 2006). Uma de nossas professoras entrevistadas informou que a Faculdade de Educação pensou no noturno ao montar um curso com carga horária maior que a solicitada pelas diretrizes curriculares de pedagogia, para que o aluno do noturno perdesse menos de seu curso superior, já que a hora-aula do turno da manhã e da noite são diferenciadas. Houve, inclusive, uma proposta da Faculdade de Educação de mudança na contabilização dos tempos de aula da UERJ, passando de hora-aula que atualmente são 50 minutos no turno da manhã e 45 minutos no turno da noite, para hora relógio. O curso noturno, de acordo com esta mudança, precisaria ter aulas aos sábados para cumprir a carga horária. Entretanto, a proposta não foi aprovada pelas instâncias superiores. 
Estudos que avaliam o fator tempo na formação acadêmica de estudantes (Crahay, 2002) verificam que este é um fator bastante prejudicial na formação destes. Na grade de horários da UERJ (quadro 3), observamos como o curso noturno se encontra com uma distribuição de horários mais apertada que os horários da manhã e da noite.

\section{Quadro 3 - Grade de horários da UERJ}

\begin{tabular}{||c|c|}
\hline \multicolumn{2}{|c|}{ Horário } \\
\hline M1/M2 & $7: 00 / 8: 40$ \\
\hline \hline M3/M4 & $8: 50 / 10: 30$ \\
\hline M5/M6 & $10: 40 / 12: 20$ \\
\hline T1/T2 & $12: 30 / 14: 10$ \\
\hline T3/T4 & $14: 20 / 16: 00$ \\
\hline T5/T6 & $16: 10 / 17: 50$ \\
\hline N1/N2 & $18: 00 / 19: 30$ \\
\hline \hline N3/N4 & $19: 35 / 21: 05$ \\
\hline N5/N6 & $21: 10 / 22: 30$ \\
\hline
\end{tabular}

\section{Fonte: Disponível em http://www.uerj.br/}

Além do fator da carga horária ser de 10 minutos a menos em cada disciplina por dia no curso noturno - ou seja, disciplinas que possuem quatro tempos semanais perdem no mínimo 20 minutos semanais (1h20 mensais, cerca de 5h20 minutos durante todo o curso) -, a maioria delas não começa nem termina no horário.

No curso noturno a aula começa às seis, mas às seis horas você tem meia dúzia numa turma de quarenta. Eles começam a chegar efetivamente seis e meia. A aula começa seis e meia, mas na medida em que vai começando você é obrigado a retomar algumas coisas pra fazer o grupo acompanhar. Então, a aula começa efetivamente às seis e meia e no último tempo a aula acaba às dez horas. Você não consegue levar até dez e dez, você já não consegue porque tem o último horário do trem [...] O único tempo que poderia durar inteiro é aquele do meio, intermediário, que vai de sete e meia às nove. Mas sete e meia pra quem veio correndo, chegou atrasado e entrou na sala pra assistir à aula e ainda vai pegar a noite toda, é o horário que ele tem pra ir ao banheiro, pra fazer um lanche e não sei mais o quê. Então, esse segundo tempo também começa dez para às oito, porque você não tem intervalo e se não tem o horário do intervalo, então cria-se. Então, a aula começa 
efetivamente dez para as oito e vai até nove. E o último tempo não tem jeito, tem que começar 21h. [P7]

Os dois tempos iniciais e finais do curso noturno possuem um tempo efetivo de trabalho de cerca de 1 h05 minutos, quando deveria ser de 1 h30 minutos. A diferença de tempo em comparação ao turno da manhã é de aproximadamente 35 minutos, contando os dez minutos a menos, o que já está institucionalizado. O primeiro tempo da manhã também possui uma perda, mas de cerca de 15 minutos, segundo os professores. O último tempo da manhã, que deveria terminar às 12h20, sofre com a saída de alguns estudantes após 12h, mas geralmente os professores conseguem levar suas aulas até o horário final, $12 \mathrm{~h} 20$.

A aula da manhã começa as sete, às vezes 07h10min, 07h15min, mas eu começava às sete.

Entrevistadora: Nesse horário você já estava com um grupo bom de alunos?

Sim, sobre isso eu não tenho queixa. À noite isso já não ocorre. [...] À noite acho que a grande questão do horário é o transito, porque eles sempre dizem que o transito é que os faz se atrasar. Tem umas meninas que sempre falam: 'professora saí da escola [que dão aula] às 5 horas da tarde e olha a hora que eu estou chegando', então, e o nosso horário noturno é às 18 horas, então, torna as coisas normalmente difíceis. [P4]

A partir de levantamento sobre pesquisas que analisaram o componente tempo para a aprendizagem acadêmica, Crahay (2002) observa que a maioria dos estudos verifica que há uma forte correlação entre quantidade de ensino, medida pelo tempo dedicado ao ensino, e o rendimento dos estudantes nas mais diversas disciplinas da educação básica. Os estudos analisados por Crahay evidenciam que a quantidade de tempo voltada ao ensino, tem efeitos na aprendizagem de estudantes desde a educação infantil até o ensino médio. Ou seja, quanto mais os estudantes são expostos aos processos de aprendizagem, mais eles obtêm retorno acadêmico.

Embora nossa pesquisa não tenha analisado o rendimento acadêmico dos estudantes por meio de nota nas avaliações ${ }^{5}$, destacamos que a perda pelos estudantes do curso noturno de cerca de 1 h10 minutos de conteúdo curricular diariamente, em relação aos estudantes do curso diurno de pedagogia, representa

\footnotetext{
${ }^{5} \mathrm{O}$ estudo de Peixoto (2004) verificou que há pouca diferenciação entre rendimentos de estudantes do diurno e noturno, ao se analisar o coeficiente de rendimento do curso.
} 
grandes desigualdades no tempo dos alunos de experienciar os processos de formação destes estudantes. Em média, mensalmente, são perdidas aproximadamente 24 horas de estudo, e, por ano de estudo, considerando oito meses efetivos de aula, por volta de 192 horas. Ao longo dos quatro anos de curso, nossos estudantes terão perdido 768 horas, ou 178 dias letivos, considerando as 4h30min de aula diária.

Observamos que a carga horária do curso de pedagogia da UERJ, de 3890, 790 horas acima do exigido pela legislação brasileira, apenas cobre parte das perdas do curso noturno com relação à carga horária mínima exigida para o nível superior. Entretanto, não é possível considerar que o curso ofereça as mesmas oportunidades nos dois turnos.

Ao tratarmos deste aspecto, salientamos ainda que o tempo de aula e o tempo investido pelo aluno nas atividades acadêmicas possuem relações diferentes. Crahay (2002), ao apresentar os resultados do estudo de Bloom (1953), que filmou aulas de estudantes universitários e depois pediu para que cada um avaliasse o tempo de envolvimento na aula, relata que a maioria demonstrou estar atenta a cerca de $64 \%$ nos momentos de exposição e $55 \%$ nos momentos de discussão. No entanto, tais resultados são questionados pelo autor, tanto nos aspectos metodológicos, quanto na relação entre tempo de investimento do aluno nas atividades escolares e sua relação com a aprendizagem. Nosso objetivo ao realizar tal ponderação é o de apontar para outros possíveis aspectos de aproveitamento do curso por nossos estudantes, mas que nossos dados não permitem analisar. No entanto, este é um aspecto relevante, visto que estudantes do noturno estariam mais cansados devido à rotina diária, o que poderia afetar suas condições de atenção e investimento nos processos escolares. Como um dos nossos professores relatou, o estudante do diurno ao menos está menos cansado ao vivenciar as aulas matutinas. 


\subsection{2}

\section{Análise da grade curricular}

Com base na metodologia de análise dos currículos das licenciaturas utilizada por Gatti e Nunes (2008), agrupamos as disciplinas do currículo do curso de pedagogia estudado segundo as categorias por elas utilizadas de modo a ter um parâmetro para comparação dos dados. Para tanto, atentamos para o número de créditos atribuídos a cada disciplina, de modo que todas possam ter o mesmo peso na análise.

Consideramos ainda que a carga horária dedicada às atividades culturais, não computadas como créditos, é acompanhada pelo professor de pesquisa e prática pedagógica, disciplina esta cujo professor acompanha o aluno durante dois anos. Outro destaque necessário é sobre as disciplinas que tratam dos conteúdos do currículo da educação básica. Sua nomenclatura sempre vem acompanhada de "para crianças, jovens e adultos", por exemplo, metodologia de ensino de história para estes três públicos. No entanto, a metodologia das disciplinas específicas para o trabalho com EJA nem sempre é contemplada, como pudemos ouvir dos estudantes, e, inclusive, por minha própria experiência enquanto aluna. 
Quadro 4 - Distribuição das disciplinas curriculares em áreas de conhecimento

\begin{tabular}{|c|c|c|c|}
\hline \multicolumn{2}{|l|}{ Categorias } & $\mathrm{N}$ & $\%$ \\
\hline \multirow{3}{*}{$\begin{array}{l}\text { Fundamentos } \\
\text { da educaçáricos }\end{array}$} & Fundamentos teóricos da educação & 8 & 13,3 \\
\hline & Didática geral & 3 & 5 \\
\hline & Subtotal & 11 & 18,3 \\
\hline \multirow{5}{*}{$\begin{array}{l}\text { Conhecimentos } \\
\text { Relativos aos sistemas } \\
\text { educacionais }\end{array}$} & Sistemas educacionais & 3 & 5 \\
\hline & Currículo & 1 & 1,6 \\
\hline & Gestão escolar & 1 & 1,6 \\
\hline & Ofício docente & 1 & 1,6 \\
\hline & Subtotal & 6 & 10 \\
\hline \multirow{4}{*}{$\begin{array}{l}\text { Conhecimentos } \\
\text { relativos à formação } \\
\text { profissional específica }\end{array}$} & $\begin{array}{l}\text { Conteúdos do currículo da educação } \\
\text { básica (infantil e fundamental) }\end{array}$ & 6 & 10 \\
\hline & $\begin{array}{l}\text { Didáticas específicas, metodologias e } \\
\text { práticas de ensino }\end{array}$ & 7 & 11,6 \\
\hline & Tecnologias & 1 & 1,6 \\
\hline & Subtotal & 14 & 23,3 \\
\hline \multirow{5}{*}{$\begin{array}{l}\text { Conhecimentos } \\
\text { relativos às modalidades } \\
\text { e níveis de ensino }\end{array}$} & Educação especial & 4 & 6,6 \\
\hline & Educação infantil & 3 & 5 \\
\hline & EJA & 4 & 6,6 \\
\hline & Contextos não escolares & 2 & 3,3 \\
\hline & Subtotal & 13 & 21,7 \\
\hline \multicolumn{2}{|l|}{ Outros saberes } & 9 & 15 \\
\hline \multicolumn{2}{|l|}{ Pesquisa e TCC } & 7 & 11,7 \\
\hline \multicolumn{2}{|l|}{ Atividades complementares } & $\begin{array}{l}200 \\
\mathrm{~h}\end{array}$ & \\
\hline Total & & 60 & 100 \\
\hline
\end{tabular}

Fonte: Elaboração própria.

A análise da grade curricular do curso de pedagogia da UERJ permite observar os enfoques da formação oferecida. Há preocupação em abordar conhecimentos relativos às diferentes modalidades e níveis de ensino, onde, na UERJ, encontram-se $21,7 \%$ das disciplinas. Neste aspecto, observamos a pequena fatia relativa aos estudos dos contextos não escolares, tão almejados pelos estudantes que lá estudam, com apenas duas disciplinas específicas. Outro aspecto marcante do curso é o enfoque no componente pesquisa e trabalho de conclusão de curso (TCC), correspondendo a $11,7 \%$ de todas as disciplinas do curso.

Ao olhar para o currículo da instituição estudada, temos em consideração o alerta que Canário (2005, p. 70) faz: 
A forma mais adequada de analisar o currículo não consiste em averiguar o que fazem os professores, mas, sim, em questionar o que fazem os alunos e em que medida e de que forma lhes é "dada a palavra". Dar a palavra aos alunos tem como atitude complementar, lógica e necessária, uma atitude de escuta, por parte dos professores da formação inicial, quer em relação aos alunos, quer em relação aos profissionais da área.

Seu alerta condiz com nossa proposta de cruzar os olhares sobre o curso de pedagogia, especialmente numa comparação entre seus dois turnos. Durante nossas conversas pelos corredores da instituição ou até nos relatos enviados pelos estudantes, e mesmo no discurso dos professores, percebemos que a principal queixa dos estudantes é com relação ao currículo do curso, especialmente por este possuir um número muito grande de disciplinas obrigatórias por semestre, além das eletivas. Segundo os alunos, isso impossibilita que eles aprofundem nos assuntos do curso, "passa-se muito superficialmente por elas, pois não há condição de se aprofundar em tantas disciplinas ao mesmo tempo", "e vai ficando para depois" [estudantes do oitavo período, noturno]. Alguns ainda avaliam que tal currículo "não permite ao aluno conhecer novas disciplinas e se aventurar na própria faculdade em outras atividades" [estudante do oitavo período, diurno].

Uma segunda crítica é quanto ao conteúdo das próprias disciplinas.

O curso de Pedagogia da UERJ está restrito à educação infantil, abordando pouco o ensino profissional, educação de jovens e adultos e a questão da saúde nos espaços escolares. [R24, estudante do diurno]

Tenho algumas matérias que poderiam ser suprimidas, já que a gente vê não ter muita utilização. Tenho matérias com nomes diferentes que o conteúdo é o mesmo! Isso deixa maçante até para estudar. [R11, estudante do noturno]

A proposta do curso faz uma opção à formação do professor para atuar nos diferentes níveis e modalidades de ensino, o que fica muito claro no perfil de aluno que se pretende formar, como vimos. A vivência do currículo, no entanto, parece ser diferenciada, como se verifica na fala dos estudantes.

A licenciatura em pedagogia da UERJ promove a sensação entre seus estudantes de que o curso é direcionado à formação do profissional que o capacite a exercer seu trabalho na educação infantil, gerando sentimentos contraditórios 
conforme os interesses de seus estudantes. Primeiro, por confirmar a opção de muitos de atuarem em um futuro próximo na área da educação infantil, no entanto, para outros fazendo com que desanimem com o curso, como observamos na seguinte fala: “95\% dos professores e disciplinas são voltadas para a área da educação infantil. Eles esquecem que [o profissional formado em] pedagogia pode atuar em muitas outras áreas." [R33, estudante do noturno, originalmente da manhã].

Nas conversas informais com os estudantes esse também foi um aspecto ressaltado pelos alunos, um dos quais comentou:

Eu até procuro fazer os trabalhos da faculdade ligados à EJA, porque as matérias aqui na faculdade são [por exemplo], matemática para crianças, jovens e adultos, mas o professor só fala de matemática para criança, que é o que ele tem contato, e $\mathrm{o}$ jovem e $\mathrm{o}$ adulto ficam à margem. Então, sempre tento puxar [minhas discussões] para o jovem e o adulto. Eu tento me virar e mesmo para achar que vi alguma coisa [nesta área]. [Entrevista com estudante do sétimo período, noturno]

Por iniciativa do estudante, ele busca conhecimento na área de EJA, mesmo que as disciplinas não cumpram o objetivo de discutir a educação de jovens e adultos a que se propõe. Alguns professores também reconhecem a queixa, acrescentando que os estudantes reclamam, inclusive, das temáticas e textos repetidos nas diferentes disciplinas. Os estudantes oriundos da penúltima reformulação do curso já reclamavam do excesso de enfoque na educação infantil, como vemos acima. Tal questão foi levantada por Canário (2005), ao salientar que ouvir aqueles que vivenciam o currículo, faz parte do processo avaliativo de tal currículo.

O que parece acontecer é que algumas disciplinas de fundamentação, ou consideradas de base comum do curso, tem como foco o processo de aprendizagem, recorrendo muitas vezes à fundamentação da psicologia, e que normalmente são trabalhadas a partir do desenvolvimento infantil. Por serem agrupadas às disciplinas específicas da educação infantil, como lúdico, infância e políticas de educação infantil, infância e cultura, currículo da educação infantil, estágio entre outras, dão essa caracterização ao curso. Além disso, quase todas estas disciplinas são cursadas nos primeiros períodos. A única formação que 
permeia todo o curso é aquela voltada aos anos iniciais, com disciplinas do início ao fim do curso.

Ponderemos, ainda, com Lopes e Costa (2009, p. 338), que "os alunos tendem mais facilmente a considerar os conteúdos interessantes quando as suas expectativas relativamente ao nível de exigência do curso se concretizam". Lembramos que nossos estudantes, em sua maioria (mais de 70\%), gostariam que o curso fosse mais exigente. Esse fator pode explicar, em parte, as inúmeras reclamações com relação ao conteúdo do curso.

Outra questão diz respeito às disciplinas que formam o pedagogo para atuar nas instituições e movimentos sociais, as quais são realizadas a partir do quinto período. Em nossas conversas com os estudantes, um deles, do noturno, falou: “agora que já estou terminando o curso está mais interessante, pois temos disciplinas com enfoques mais políticos e sociais". Cabe considerar também que "o nível de interesse aumenta à medida que o curso vai progredindo, já que é nos últimos anos que os conteúdos assumem um cariz mais prático" (idem). Para os autores, em termos gerais, os estudantes passam a ter interesse maior pelos conteúdos do curso, quando estes se mostram atualizados, pertinentes, com boa articulação, seja na área de estudo, seja numa perspectiva de inserção no mercado de trabalho.

Para Lopes e Costa (2009, p. 342),

nalguns casos, a avaliação positiva da estrutura curricular é apenas feita retrospectivamente, depois de terem concluído a sua formação, sendo que afirmam não terem tido capacidade e maturidade para compreenderem a pertinência e validade da organização dos cursos no período em que os frequentaram. 


\section{3}

\section{Trajetória no curso de pedagogia: perfil acadêmico e condições para estudo}

A trajetória dos estudantes dentro do curso de pedagogia parece contraditória e, como os próprios estudantes mencionam, "algumas experiências foram muito boas, outras foram péssimas" [Estudante do $8^{\circ}$ período, noturno].

Precisei conciliar os estudos com o trabalho, o que me deixou distante do curso e muito sobrecarregada. Vejo esse reflexo negativo agora, quando escrevo minha monografia. (...) Gostaria de ter tido mais tempo e mais condições financeiras de me dedicar integralmente ao curso. [R34, aluna do oitavo período, noturno]

Os alunos não estudam. Isso é um problema na universidade. Eles estão sempre fazendo muita coisa... Eles não têm tempo pra estudar... [Se programar:] 'hoje eu vou sentar e estudar, vou ler...' que seria o principal, eu não vejo os alunos fazendo isso. [P16]

As falas acima expressam uma das principais dificuldades apontadas tanto por alunos como por professores: a falta de tempo para dedicação ao estudo. Há um sentimento geral dos professores do curso de pedagogia estudado com relação aos estudantes. Os alunos não estudam, não possuem o hábito de estudo. Isto fica evidente quando observamos as respostas dos estudantes sobre o tempo por eles dedicado ao estudo semanalmente além das aulas. 
Tabela 16 - Tempo dedicado ao estudo acadêmico semanalmente.

\begin{tabular}{|c|c|c|c|c|c|c|c|c|c|c|c|}
\hline & & \multicolumn{9}{|c|}{ Tempo dedicado, por semana, ao estudo acadêmico } & \multirow[b]{2}{*}{ Total } \\
\hline & & $1 \mathrm{~h}$ & $\begin{array}{l}1 \mathrm{~h} 01 \\
\text { até } 2 \mathrm{~h}\end{array}$ & $\begin{array}{l}2 \mathrm{~h} 01 \\
\text { até } 3 \mathrm{~h}\end{array}$ & $\begin{array}{l}3 \mathrm{~h} 01 \\
\text { até } 4 \mathrm{~h}\end{array}$ & $\begin{array}{l}4 \mathrm{~h} 01 \\
\text { até } 5 \mathrm{~h}\end{array}$ & $\begin{array}{l}5 \mathrm{~h} 01 \\
\text { até } 7 \mathrm{~h}\end{array}$ & $\begin{array}{l}\text { Acima } \\
\text { de } 7 \mathrm{~h}\end{array}$ & $\begin{array}{l}\text { Só estudo } \\
\text { em véspera } \\
\text { de prova e } \\
\text { para fazer } \\
\text { os trabalhos }\end{array}$ & $\begin{array}{l}\text { Nenhuma, } \\
\text { apenas } \\
\text { assisto às } \\
\text { aulas }\end{array}$ & \\
\hline \multirow[t]{2}{*}{ Diurno } & $n$ & 2 & 5 & 3 & 5 & 8 & 5 & 26 & 46 & 1 & 101 \\
\hline & $\%$ & $2.0 \%$ & $5.0 \%$ & $3.0 \%$ & $5.0 \%$ & $7.9 \%$ & $5.0 \%$ & $25.7 \%$ & $45.5 \%$ & $1.0 \%$ & $100.0 \%$ \\
\hline \multirow[t]{2}{*}{ Noturno } & $\mathrm{n}$ & 6 & 10 & 5 & 9 & 17 & 9 & 31 & 57 & 0 & 144 \\
\hline & $\%$ & $4.2 \%$ & $6.9 \%$ & $3.5 \%$ & $6.3 \%$ & $11.8 \%$ & $6.3 \%$ & $21.5 \%$ & $39.6 \%$ & $0.0 \%$ & $100.0 \%$ \\
\hline \multirow[t]{2}{*}{ Total } & $\mathrm{n}$ & 8 & 15 & 8 & 14 & 25 & 14 & 57 & 103 & 1 & 245 \\
\hline & $\%$ & $3.2 \%$ & $5.9 \%$ & $3.2 \%$ & $5.9 \%$ & $10.3 \%$ & $5.9 \%$ & $24.1 \%$ & $41.1 \%$ & $.4 \%$ & $100.0 \%$ \\
\hline
\end{tabular}

Fonte: Questionário SOCED / Pesquisa: Cursos de pedagogia - estudos de caso e desafios à produção de qualidade do ensino fundamental.

Os dados indicam duas situações controversas, a primeira das quais é que a grande maioria (39,6\% entre os alunos do noturno e 45,5\% entre os estudantes do diurno) afirma não ter regularidade para estudo, dedicando-se a seu curso apenas na ocasião de trabalhos acadêmicos e véspera de provas. Esperávamos, no entanto, que o percentual fosse maior entre os estudantes do curso diurno, já que este teria mais tempo para estudo. Faldini et al. (2003), em estudo sobre o tema, comprovaram que entre estudantes de diurno e noturno, os primeiros, apesar de estudarem mais, revelavam maior variação entre as horas dedicadas ao estudo; ou seja, havia quem estudava muito pouco e outros que estudavam muito. Outro dado do estudo é que estudantes do curso noturno tendem a estudar mais em épocas de provas que os estudantes do curso diurno, o que entendemos ser o resultado do fato de que estudantes do curso diurno possuem condições de se dedicarem com mais regularidade aos estudos, criando assim, um hábito. Segundo pesquisa de Nunes (2012), 41,2\% dos estudantes de pedagogia estudam apenas de uma a duas horas semanais.

Entretanto, nas questões em que solicitamos aos estudantes que falassem sobre suas práticas de estudo, a grande maioria respondeu o que podemos chamar de politicamente correto. A maioria dos estudantes, $72,7 \%$, declarou que adora ir a uma livraria ou biblioteca, e a grande totalidade, $86,8 \%$, afirmou que já comprou livros para seu curso. 
Com relação ao hábito de estudo, 31,7\% dos respondentes que estudam à noite reconheceram não possuir tal prática, porcentagem próxima aos que afirmam que só leem o que é necessário (36,7\%). Já entre os estudantes do turno da manhã, respectivamente, encontramos $21,7 \%$ e $28,8 \%$.

Observando as informações sobre o tempo de estudo e tais condições, tendemos a relativizar o tempo que dizem investir no estudo. Nosso estudante geralmente não possui condições para estudar, especialmente no noturno, cuja grande maioria trabalha. A maior parte dos estudantes, 83,2\%, declarara que possui dificuldade em ler previamente os textos indicados para as aulas, sem grandes diferenças entre os dois turnos, $85,1 \%$ no noturno e $81,3 \%$ no diurno, como observamos na tabela 17. Este dado parece indicar que não é uma dificuldade encontrada apenas por quem trabalha e estuda, mas é uma dificuldade geral dos estudantes, e muitos, especialmente aqueles que, pela precariedade de sua trajetória escolar, se veem limitados a escolher os cursos de vestibular mais fáceis como é o caso de pedagogia.

Destaco que nossos estudantes são oriundos de trajetórias escolares precárias, marcadas usualmente por pouco desenvolvimento do hábito de estudo; ou seja, não é prática comum destes alunos a reserva de um tempo diário para se dedicar às atividades escolares. Assim, eles levam tal vivência para a universidade e nem sempre desenvolvem o hábito de estudo acadêmico, geralmente exigido nos ambientes universitários, como leituras dos textos solicitados e anotações das aulas, realização de fichamentos dos textos, bem como realização de pesquisas adicionais aos programas propostos. É clarividente, entretanto, que a universidade não fomente tais práticas de estudo entre seu alunato, o que pode ser resultado de uma interpretação de que esta clientela, por estar no ensino superior, já dominaria os processos acadêmicos. Não obstante, como evidencia Coulon (2008), ao ingressarem no ensino superior, os estudantes passam por um processo de aprendizado da vida universitária, necessitando, por vezes, de informações sobre como orientar seus estudos de modo a contribuir para seu processo de aprendizagem, como também encontramos em Lopes e Costa (2007). Uma estudante do noturno menciona suas dificuldades no início do curso, em especial com textos e trabalhos, mas ressalta que aos poucos, com esforço próprio, "buscando saber com os colegas e professores" e também através de pesquisas na 
biblioteca, foi encontrando meios de superar suas limitações. A tabela 17 apresenta algumas das principais dificuldades acadêmicas enfrentadas por nossos estudantes.

Tabela 17 - Dificuldades acadêmicas enfrentadas pelos estudantes

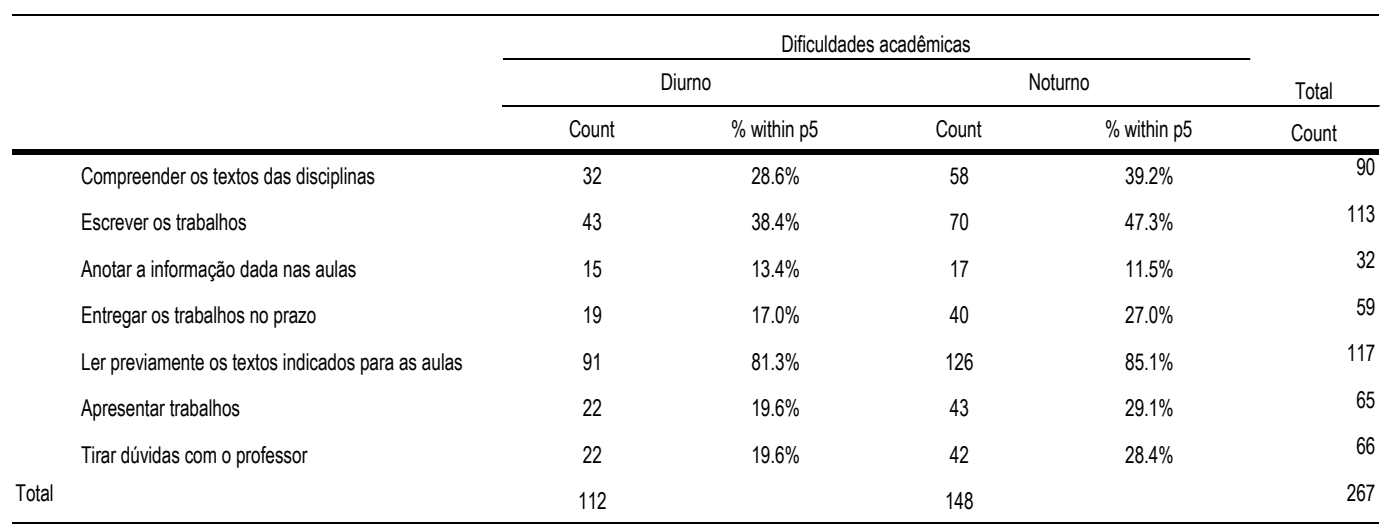

Fonte: Questionário SOCED / Pesquisa: Cursos de pedagogia - estudos de caso e desafios à produção de qualidade do ensino fundamental.

Entre o grupo de estudantes do noturno, 39,2\%, relatam que também possuem dificuldade em compreender os textos discutidos nas disciplinas, já esta porcentagem entre os que estudam pela manhã é de 28,6\%. Essa incompreensão dos textos leva-nos a refletir sobre a pouca autonomia dos estudantes para estudar. Tempo escasso e compreensão difícil certamente resultariam em dificuldades acrescidas à sua formação. Um dos professores entrevistados, P15, menciona a falta de paciência para o estudo.

Eu vejo uma porção de gente muito interessada, querendo saber, mas sem paciência com o estudo. O estudo é um ato de paciência. Você precisa sentar e ter calma. (...) Não dá pra você ler uma coisa e ficar pensando na outra que você deixou de ler, entendeu? É um negócio assim, que tem que ser feito com mais calma e cada vez você tem menos tempo, então, por mais que o aluno seja interessado, ele não dá conta. Ele dá conta de alguma forma de uma primeira leitura no ônibus ou no trem. [P15]

A leitura é, inclusive, um dos graves problemas do curso destacados pelos professores. Alguns buscam rever as estratégias das aulas. Há quem dê dois textos 
por mês, nas disciplinas em que há duas aulas semanais; há quem dê um texto semanalmente; há aqueles que cobram resenha do texto; há os que realizam dinâmicas de leitura com textos mais curtos dentro da sala de aula (uma professora mencionou que elaborou um livro com esta característica para ser trabalhado em suas disciplinas); e ainda há aqueles que, apesar de deixarem uma bibliografia extensa para o aluno que quiser consultar, não solicitam a leitura para a aula. As queixas dos alunos sobre este assunto são muitas.

A experiência com milhares de textos por disciplina não é muito legal, pois algumas vezes pesa demais e é até torturante, pois são textos [por] vezes complexos e grandes. [R1, aluna do oitavo período, noturno, originária do diurno]

Tive muita dificuldade com os textos e com alguns trabalhos pedidos, mas, aos poucos, fui me adaptando. [R34, aluna do oitavo período noturno].

Com a possibilidade de realização de apenas uma primeira leitura superficial, quando se é realizada, torna-se praticamente impossível para o estudante conseguir "extrair a ideia do autor, argumentar e relacioná-la com a contemporaneidade (...), construir uma densidade analítica e crítica" [P10], o que normalmente se exigiria em um curso superior.

Entretanto, apesar da pertinência dos textos indicados pelos professores, uma aluna sente falta de uma discussão mais densa.

Os textos são bem interessantes e fomentariam discussões fantásticas, porém, a maioria das alunas que ingressam no curso geralmente não participa dos debates, não levanta questionamentos e não parece se interessar muito pelo que estão estudando. Isto me deixa muito triste, pois acredito que se minhas colegas participassem mais da aula, a minha graduação teria sido bem mais rica. [R50, aluna do sétimo período, manhã].

Outra notável dificuldade, logicamente associada à dificuldade de leitura, e que foi evidente inclusive nos relatos por mim analisados, é a escrita. A limitação para escrever os trabalhos exigidos pelo curso é bastante alta nos dois turnos, $47,3 \%$ entre os respondentes que estudam no noturno e mais de um terço $(38,4 \%)$ entre os estudantes do diurno. 
A escrita está deficiente, bem deficiente. Há alguns casos extremos. O extremo de você não conseguir compreender um parágrafo. (...) A construção de uma ideia, a argumentação, a coesão, a construção de um texto (...). [Tudo] está muito ruim. [P10]

Eles têm uma dificuldade de expressão muito grande, o que é complicado porque vão se tornar alfabetizadores e escrevem muito mal. [P14]

Ele tem que saber a norma culta da Língua Portuguesa. Ele tem que saber operar com isso. [P1]

Os estudos de Gimenes e Pullin (2010) ressaltam a precariedade das habilidades de escrita e matemática básica e mesmo a habilidade oral dos estudantes de pedagogia. Zago (2006) assinala o mesmo problema para estudantes do ensino superior, que necessitariam, segundo a autora, de melhores condições para se dedicarem ao curso superior, tanto condições humanas, como financeiras para estudo.

Para os professores entrevistados, a escrita precisa ser desenvolvida durante todo o curso. Três professores mencionam que ao darem trabalhos escritos, eles possibilitam que o aluno escreva e reescreva até tirar dez. Essa é uma forma que os professores encontraram de enfrentar este problema.

A escrita está associada a escrever corretamente, a coisa das experiências prévias de escrita. Essa coisa da redação é um problema, sobre como a pessoa domina a língua materna, enfim. Então você tem um fato, uma questão, mas que do meu ponto de vista essa questão precisa ser enfrentada. Não é suprimir a escrita como alguns colegas fazem. [P6]

Eu não sei se eu estou ficando mais velha, mas eles estão chegando cada vez mais jovens e com muitas deficiências. Não sabem nem escrever. Isso é impressionante. Por exemplo, uma coisa que eu faço nas minhas disciplinas (...). Geralmente, a minha disciplina é dada no $5^{\circ}$ período. Estão quase chegando à monografia. Eu faço eles escreverem. Eu tenho um método que me dava muito mais trabalho. Eu dava trabalho de escrita individual. E eles escreviam. Aí eu revisava. Eles podiam escrever quantas vezes quisessem até tirar dez. Tiravam nove e meio. Tiravam dez. Porque eu via que eles não sabem... Eles sabem discutir muito bem, mas eles não conseguem escrever. Aí de repente começa a fazer monografia. E o cara bloqueia. [P12] 
Entretanto, como uma das professoras comenta, muitos alunos ficam satisfeitos com a nota inicial e não se preocupam em desenvolver a escrita, reescrever o trabalho, abrindo mão da oportunidade dada de melhorar seu texto, logo, de escrever melhor. Como exemplo da escrita apressada, aquela permeada de falta hábito e de condições adequadas ao desenvolvimento do processo de escrever, cito o exemplo de um estudante do noturno. Durante a aplicação dos questionários, ele disse que não poderia preenchê-lo naquele momento porque estava terminando de escrever um trabalho que era para a próxima aula, mas que assim que o terminasse, preencheria o questionário e me entregaria onde eu estivesse. Entretanto, bem menos estudantes afirmam possuir dificuldades em entregar os trabalhos no prazo (27\% do noturno e $17 \%$ do diurno), conforme observado na tabela 17. Vale ressaltar os limites do questionário, como Collins (2008) destaca, muitos o respondem respeitando aquilo que seria o politicamente correto.

Para Charlot, o processo de aprendizagem está ligado a um desejo interior.

Ninguém pode aprender sem uma atividade intelectual, sem uma mobilização pessoal, sem fazer uso de si. Uma aprendizagem só é possível se for imbuída de desejo (consciente ou inconsciente) e se houver um envolvimento daquele que aprende. Em outras palavras: só se pode ensinar a alguém que aceita aprender, ou seja, que aceita investir-se intelectualmente. (Charlot, 2005: 76).

Com interesses diversos dentro do curso de pedagogia, parece que muitos estudantes não se envolvem com o curso, não são mobilizados intelectualmente para aprender para saber, para conhecer.

A gente tem um curso pra formar um determinado profissional, onde a maioria absoluta não tem nada a ver com esse curso. Uma coisa é ter, como eu sempre tive aqui, um grupo pequeno que passava pelo curso e que não tinha nada a ver com sua história, enquanto o outro [grupo] pelo menos estava em dúvida. [P11]

Por outro lado, as condições para dedicação ao curso também não são favoráveis, como vimos acima. Este mesmo professor ressalta a dificuldade que é lecionar especialmente para o público da noite, sendo necessário buscar formas de 
motivar o aluno que parece estar desmotivado ou mesmo exausto para investir no estudo.

Por compromisso pessoal eu dou aula à noite, porém, quando eu estou muito esgotado eu evito dar aula à noite. Eu evito porque eu pego um aluno que chega extremamente cansado. É muito difícil. Eu tenho muita dificuldade de mobilizar o aluno da noite. Muita dificuldade. Eles chegam com muita resistência, então eu viro um professor de cursinho que tenta fazer gracinha pra trazer o cara, que tenta de alguma forma..., e quando a gente não toma cuidado isso se perde, o que é o óbvio, né? E se perde, fica muito ruim. Então, quando não é esse tipo de comportamento, é o tipo de comportamento mesmo do cara que não entrega nada, não lê. [P11]

Comparados às demais licenciaturas, alguns professores até acham que os alunos das licenciaturas duras, como física, matemática, química, possuem disposição e interesse maior para estudar e trabalhar que os do curso de pedagogia. Na opinião de um dos docentes, estes alunos "estão mais acostumados a um ritmo de estudo mais intenso" [P16].

Uma aluna do curso de pedagogia faz essa diferenciação entre a participação de suas colegas de curso e dos colegas de licenciatura: "Nas matérias que fiz com turmas de licenciatura e pedagogia, os estudantes de licenciatura participavam imensamente mais que as alunas de educação" (R50, aluna do sétimo período, manhã). A literatura sugere que os processos de interação entre os colegas de uma turma, entre os que estão mais adiantados com aqueles com maiores dificuldades, resultam em influência positiva sobre o percurso acadêmico dos estudantes e apresentam ganhos com relação à motivação, expectativas quanto aos estudos, bem como quanto aos aspectos não acadêmicos da vida (Bressoux, 2003; Alves \& Soares, 2007). Tal influência é chamada de efeito pares.

Outro importante elemento para se olhar as condições de nossos estudantes no processo de usufruir da vida acadêmica está no acesso aos programas de bolsas da universidade. De acordo com nossos dados, não foi encontrada grande diferenciação entre os estudantes do diurno e noturno neste aspecto, uma vez que identificamos que os alunos do curso noturno usufruem deste recurso apenas um pouco menos que os alunos do diurno, como observamos na tabela 18 . O que percebemos, no entanto, é que os estudantes do noturno que recebem algum tipo de bolsa da universidade estão, em sua maioria, entre os poucos $25 \%$ de 
estudantes que não trabalham, ou seja, sua opção em estudar à noite não se deve apenas pela necessidade de se conjugar estudo e trabalho.

$\mathrm{Na}$ tabela 18 estão reunidas todas as informações sobre participação dos estudantes em atividades acadêmicas da universidade, com ou sem bolsa, desde a participação em eventos acadêmicos até em programas de bolsas da universidade, como em projetos de iniciação científica, programas de estágio de extensão, monitoria, programas de iniciação a docência e estágios administrativos na universidade. Verificamos resultados bem próximos entre os dois turnos.

\section{Tabela 18 - Participação nas atividades acadêmicas oferecidas pela universidade}

\begin{tabular}{|c|c|c|c|c|c|}
\hline & & \multicolumn{3}{|c|}{ Participa/participou das atividades acadêmicas } & \multirow{2}{*}{ Total } \\
\hline & & Sim, COM bolsa & Sim, SEM bolsa & Não & \\
\hline \multirow[t]{2}{*}{ Diurno } & $\mathrm{n}$ & 100 & 50 & 433 & 583 \\
\hline & $\%$ & $17.2 \%$ & $8.6 \%$ & $74.3 \%$ & \\
\hline \multirow[t]{2}{*}{ Noturno } & $\mathrm{n}$ & 113 & 83 & 720 & 916 \\
\hline & $\%$ & $12.3 \%$ & $9.1 \%$ & $78.6 \%$ & \\
\hline Total & $\mathrm{n}$ & 213 & 133 & 1153 & 1499 \\
\hline
\end{tabular}

Fonte: Questionário SOCED / Pesquisa: Cursos de pedagogia - estudos de caso e desafios à produção de qualidade do ensino fundamental.

Quando olhamos para os programas de bolsas oferecidos pela universidade (gráfico 5), percebemos que sempre há uma diferença maior entre os dois turnos, sempre com um número maior de estudantes do curso diurno que usufruem destas bolsas. 


\section{Gráfico 5 - Participação nas diferentes atividades acadêmicas oferecidas pela universidade}

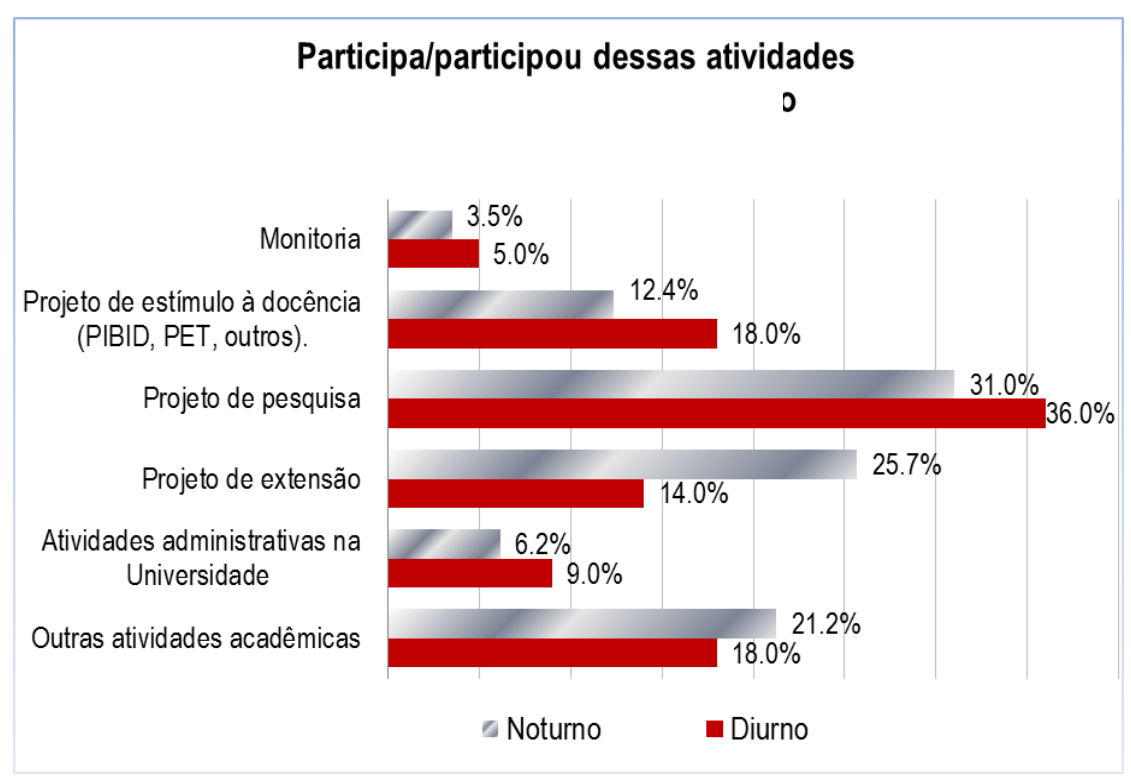

Fonte: Questionário SOCED / Pesquisa: Cursos de pedagogia - estudos de caso e desafios à produção de qualidade do ensino fundamental.

Com relação à participação em projetos de iniciação à pesquisa, percebemos que $36 \%$ dos estudantes do diurno aproveitam estas bolsas, enquanto que entre os estudantes do noturno, são $31 \%$. O único aspecto em que os estudantes do noturno possuem maior participação nas bolsas oferecidas na universidade se dá nos programas de extensão, o que parece sugerir que os estudantes do diurno, alocados mais frequentemente nos programas de iniciação científica e de estímulo a docência, procuram menos estes programas. $O$ fator que reuniu as demais atividades acadêmicas, como palestras, seminários ou demais atividades acadêmicas também aparece em porcentagem maior entre os estudantes do noturno, sugerindo que estes buscariam outras formas de se servirem da vida acadêmica, de acordo com sua disponibilidade.

A este grupo de bolsistas é facultada a experiência da vida universitária em todas as suas dimensões, ensino, pesquisa e extensão, o que como bem observa a estudante do curso diurno, acarreta importantes contribuições para sua formação acadêmica: 
Minha experiência como aluna tem sido proveitosa, pois estou fazendo estágio interno complementar, o que contribui para uma formação mais ligada à prática. Sei que não são todos os alunos que possuem as mesmas oportunidades. Eu faço estágio e tenho um tipo de experiência, mas convivo com alunos que não trabalham na área e dá para perceber a diferença com relação [à formação no] curso. [R10, estudante do diurno]

De modo geral, ainda é pequena a oferta de bolsas para participação nas diferentes atividades acadêmicas da universidade, contudo, percebemos que poucos são aqueles que, sem o objetivo de receberem bolsa, buscam participar deste tipo de atividade para enriquecimento de sua formação acadêmica.

Uma estratégia para garantir as mesmas oportunidades de formação aos estudantes dos dois turnos seria a existência, por exemplo, de bolsas de fixação na universidade, como destaca Peixoto (2004). Tais bolsas poderiam inclusive exigir uma contrapartida do estudante, como se dedicar a estágios no ensino público durante toda a formação - ou mesmo a atuação neste nível de ensino por determinado tempo após a formação -, mas elas deveriam dar condições financeiras reais para que estes estudantes possam escolher se dedicar exclusivamente ao curso, em especial à formação para a docência.

Por fim, quando perguntados sobre como percebem o nível de exigência do curso, nossos estudantes, em sua maioria, respondem que gostariam que o curso tivesse um nível de exigência maior. Entendo que quando os estudantes mencionam que gostariam que o curso exigisse mais deles, estão se referindo a este ritmo "menos intenso de trabalho" a que o professor fez referência. De modo geral, $73,6 \%$ dos estudantes gostariam que o curso cobrasse mais deles. Os valores, como vemos na Tabela 19, são bem próximos entre os dois turnos. 
Tabela 19 - Nível de exigência do curso

\begin{tabular}{|c|c|c|c|c|c|}
\hline & & \multicolumn{3}{|c|}{ Avaliação do nível de exigência do curso } & \multirow[b]{2}{*}{ Total } \\
\hline & & Deveria exigir MENOS & Deveria exigir MAIS & $\begin{array}{l}\text { Estou satisfeito(a) com o } \\
\text { grau de exigência }\end{array}$ & \\
\hline \multirow[t]{2}{*}{ Diurno } & $\mathrm{n}$ & 27 & 86 & 5 & 118 \\
\hline & $\%$ & $22.9 \%$ & $72.9 \%$ & $4.2 \%$ & $100.0 \%$ \\
\hline \multirow[t]{2}{*}{ Noturno } & $\mathrm{n}$ & 33 & 106 & 4 & 143 \\
\hline & $\%$ & $23.1 \%$ & $74.1 \%$ & $2.8 \%$ & $100.0 \%$ \\
\hline \multirow[t]{2}{*}{ Total } & $\mathrm{n}$ & 60 & 192 & 9 & 261 \\
\hline & $\%$ & $23.0 \%$ & $73.6 \%$ & $3.4 \%$ & $100.0 \%$ \\
\hline
\end{tabular}

Fonte: Questionário SOCED / Pesquisa: Cursos de pedagogia - estudos de caso e desafios à produção de qualidade do ensino fundamental.

Questiono, se as práticas docentes de leitura em classe, abandono da exigência de leitura, avaliações em grupo não estariam corroborando o nivelamento dos estudantes por baixo. Resultados de pesquisas sobre eficácia escolar comprovam a existência de tal situação na educação básica e que aqui discutimos no ensino superior. Segundo Alves e Soares (2007, p. 47), "as escolas estabelecem objetivos mais singelos para as turmas com nível mais baixo, sem perspectiva de alcançar alguma equidade". No estudo dos autores, uma professora chega a afirmar sobre uma turma: "eles estão num outro processo bem aquém, então não há como acompanhar [...] Não tem jeito. Então eu trabalho o básico" (idem). Tal prática pode ser considerada como juízo professoral (Bourdieu, 2012), por meio do qual professores realizam uma pré-avaliação dos estudantes em função de suas características de origem, bem como de suas habilidades de leitura e escrita, criando determinadas expectativas para determinados tipos de estudantes. Ou seja, se o curso exige menos porque os alunos são considerados mais fracos, estes ficam cada vez mais desestimulados e desacreditados, tendo acesso, portanto, a uma formação abaixo de suas expectativas. Esta situação acaba gerando um círculo vicioso, no qual desde sua trajetória na educação básica, esse futuro docente tem acesso a uma formação precária, chega ao ensino superior, e realiza um curso que oferece menos do que poderia/deveria oferecer, e ao atuar profissionalmente, nas escolas de educação básica - para onde boa parte destes estudantes se encontrará após sua formação -, oferecerá um ensino de qualidade inferior aos seus alunos. 
Contraditoriamente, os dados referentes ao nível de satisfação com o curso, de modo geral, são altíssimos nos dois turnos, pouco acima entre os estudantes do noturno (Tabela 20).

Tabela 20 - Nível de satisfação com o curso

\begin{tabular}{|c|c|c|c|c|c|c|}
\hline & & \multicolumn{4}{|c|}{ Nivel de satisfação com o curso } & \multirow[b]{2}{*}{ Total } \\
\hline & & $\begin{array}{l}\text { Muito } \\
\text { insatisfeita(o) }\end{array}$ & Insatisfeita(o) & Satisfeita(o) & $\begin{array}{c}\text { Muito } \\
\text { satisfeita(o) }\end{array}$ & \\
\hline \multirow[t]{2}{*}{ Diurno } & $\mathrm{n}$ & 1 & 12 & 52 & 5 & 70 \\
\hline & $\%$ & $1.4 \%$ & $17.1 \%$ & $74.3 \%$ & $7.1 \%$ & $100.0 \%$ \\
\hline \multirow[t]{2}{*}{ Noturno } & $n$ & 2 & 13 & 72 & 15 & 102 \\
\hline & $\%$ & $2.0 \%$ & $12.7 \%$ & $70.6 \%$ & $14.7 \%$ & $100.0 \%$ \\
\hline \multirow[t]{2}{*}{ Total } & $n$ & 3 & 25 & 124 & 20 & 172 \\
\hline & $\%$ & $1.7 \%$ & $14.5 \%$ & $72.1 \%$ & $11.6 \%$ & $100.0 \%$ \\
\hline
\end{tabular}

Fonte: Questionário SOCED / Pesquisa: Cursos de pedagogia - estudos de caso e desafios à produção de qualidade do ensino fundamental.

Apesar das críticas que os estudantes realizam sobre o curso, bem como do sentimento de que o curso deveria demandar mais deles, a razão para tão alto nível de satisfação com o curso, 83,7\%, poderia significar que este aluno está se acomodando a este ritmo mais fraco de estudo, que de modo geral parece ser aceito entre os formadores do curso. Por outro lado, Silva e Barbosa (2012), perceberam que estudantes de classe mais populares tendem a demonstrar alto nível de satisfação com o curso.

Neste capítulo, observamos que os estudantes de pedagogia, de modo geral, possuem condições precárias de se dedicarem ao ensino superior, condições estas que os acompanham desde sua trajetória escolar inicial. Os estudantes do curso noturno apresentam capital escolar/cultural ainda mais baixo que seus colegas que estudam pela manhã. Esses fatores refletem nas facilidades encontradas pelos estudantes do curso diurno de usufruírem das oportunidades oferecidas pela universidade, tendo condições de participar da vida acadêmica da universidade, seja utilizando os espaços de estudo e de lazer da universidade, seja participando de eventos, seja assumindo bolsas de pesquisa ou de outra modalidade, seja realizando estágios em suas áreas de formação e interesse. 
Por outro lado, os estudantes do noturno, em virtude de suas especificidades e de sua necessidade de trabalhar, nem sempre podem se valer de tais oportunidades oferecidas pela instituição de ensino. Além destes aspectos da vivência universitária supracitados, eles são ainda prejudicados pela variação na distribuição e oferta de determinados recursos da universidade e organização dos processos institucionais/acadêmicos, como se lê a seguir. 


\section{Entre a vivência da universidade e a vivência de um "aulão avançado"}

\section{1}

\section{O efeito universidade}

Os estudos sobre qualidade da educação, normalmente dedicados à educação básica, elencam inúmeros fatores intra e extra-escolares que promoveriam o sucesso escolar dos estudantes e que, apesar de versarem sobre outro nível de ensino, permitem-nos trazer algumas de suas discussões para o ensino superior.

Ressalto que nossa pesquisa interpreta o sucesso dos estudantes de pedagogia não por seu desempenho acadêmico, ou seja, através da nota final dos estudantes nas disciplinas cursadas ${ }^{6}$. Consideramos neste caso a qualidade como a possibilidade de o estudante aproveitar ao máximo seu curso de nível superior, podendo usufruir dos recursos institucionais e da vivência acadêmica que a instituição oferece, para além da sala de aula. Ou seja, a possibilidade de aproveitar os inúmeros espaços como bibliotecas, laboratórios, grupo de estudos e pesquisa, eventos culturais que acontecem na universidade ou que são promovidos por ela, assim como outros eventos acadêmicos como debates sobre conjuntura (política, greves, etc), seminários, congressos, simpósios entre outros.

Os estudos sobre os efeitos da escola sobre o desempenho de estudantes de origem social e culturalmente desfavorecida, medidos através dos resultados dos estudantes nas provas como SAEB e outras avaliações em larga escala (Andrade \& Soares, 2008), demonstram a complexidade deste tipo de análise, ao considerar que não apenas as variáveis individuais (como a origem social do aluno, trajetória escolar) influenciam em sua proficiência, mas reconhecem que o "impacto dos

\footnotetext{
${ }^{6}$ Os conceitos (notas) nos cursos de Ciências Humanas tendem a ser mais elevados do que nas áreas técnicas (ver a respeito Paes de Carvalho (2004).
} 
fatores sociais do coletivo frequentado pelo aluno, por exemplo, sua escola, no desempenho do aluno é maior do que no nível individual” (Soares et al., 2004). “O efeito-escola refletirá, portanto, a conjunção de fatores externos e internos, fundamentais para definir as oportunidades educacionais dos alunos" (Alves \& Soares, 2007, p. 31). Por tal razão, consideramos que tais estudos podem contribuir para pensarmos o que chamaremos de efeito universidade na formação desses estudantes de pedagogia, mais especificamente, o efeito turno, ao compararmos um mesmo curso oferecido nos períodos diurno e noturno, de uma mesma instituição universitária na formação destes futuros docentes.

Ao considerarmos o efeito universidade, entendemos com Franco et al. (2007, p. 280), pautados em Martimore (1991), que escola eficaz é "aquela que viabiliza que seus alunos apresentem desempenho educacional além do esperado, face à origem social dos alunos e à composição social do corpo discente da escola”. Para tanto, analisamos os fatores intraescolares do curso de pedagogia da UERJ, nos dois turnos, diurno e noturno, que definem as oportunidades educacionais ao mesmo tempo em que ampliam o universo de interesses culturais e acadêmicos, podendo promover, ou não, a superação de possíveis deficiências educacionais que os alunos tenham trazido de suas trajetórias escolares, permitindo que eles apresentem um aproveitamento melhor de seu curso.

A partir desses estudos, que destacam a influência da organização escolar no desempenho dos estudantes, o impacto do efeito enturmação neste processo (Alves \& Soares, 2007; Franco et al.; Costa, 2009) é destacado. Segundo Sousa e Silva (2007), o efeito enturmação pode ser baseado em diferentes aspectos, como na idade dos estudantes, no tamanho das turmas, na proposta pedagógica do professor, bem como na existência de turmas noturnas, ressaltando que este último aspecto acarreta "um desempenho pior do que o ensino diurno" (Sousa \& Silva, 2007, p. 3).

Embora a maioria das investigações enfoque a organização de turmas pela instituição escolar orientada por aspectos de aprendizagem ou comportamentais, nosso foco está sobre os dados recolhidos por estes estudos sobre o efeito enturmação que apontam para "diferenças nas oportunidades de aprendizagem de cada grupo" (Alves \& Soares, 2007, p. 39). Nosso material empírico permite aferir um maior impacto sobre o curso noturno das variações da organização do 
curso dentro da Faculdade de Educação, o que chamamos aqui de efeito turno. Os estudantes do curso noturno são prejudicados pelas diferenças de oportunidades de vivenciarem o ambiente universitário, que, por vezes, pode transformar seu curso em um "aulão", ou, como denomina Esteves (2007, p. 47), um ensino médio avançado.

Designamos como efeito turno as desigualdades na oferta de oportunidades de vivência do curso superior, causadas pelas diferenças de organização dos processos acadêmicos de um curso superior em seus turnos diurno e noturno na formação dos estudantes pesquisados. Apesar de os estudantes compartilharem do mesmo espaço físico, entendemos que há uma diferenciação entre a organização dos dois cursos, em especial na distribuição de professores entre os dois turnos. Como entendemos que aprendizagem não varia apenas em “função de características dos alunos, mas também em função da organização escolar e das práticas pedagógicas" (Alves \& Soares, 2007, p. 29), as várias características já elencadas aqui, promovem diferenças entre as formações de nossos estudantes dos cursos diurno e noturno. Para Bourdieu (1975), a instituição escolar, em nosso caso, a universidade, promove a desigualdade, favorecendo aqueles que já possuem um pouco mais. Nossos dados revelam que o efeito turno dentro de uma mesma instituição tem promovido desigualdades nas condições de formações de futuros docentes.

O que percebemos é que "tudo está organizado para que se operem discriminações negativas: os alunos mais favorecidos inicialmente são colocados nas melhores condições de desenvolvimento" (Crahay, 2008, p. 155). O sistema, mesmo que não intencionalmente, reserva aos alunos do curso diurno - que já possuem algumas vantagens econômico-sociais e melhores condições para se dedicarem aos estudos em relação aos seus colegas que estudam à noite - os melhores professores, as opções de disciplinas eletivas, e demais oportunidades de participação em eventos e atividades oferecidas pela universidade, este sistema, portanto, "não pode senão amplificar as desigualdades iniciais" (idem).

No relato que se segue, percebemos que os próprios estudantes são capazes de avaliar as diferenças entre os cursos diurno e noturno. 
Infelizmente, grande parte das disciplinas, recursos e professores se concentra no turno da manhã. O que faz declinar a qualidade do curso noturno e as chances de os alunos terminarem no tempo certo. Mas, apesar das dificuldades, exclusão e falta de interesse no investimento aos alunos do curso noturno, tenho conseguido, com muito 'suor' me manter na universidade e me formarei em breve (R30, oitavo período, noturno).

O relato da estudante aponta para os principais aspectos que diferenciam o curso noturno do diurno, cada um dos quais analisaremos separadamente. Entendemos ainda que,

no fundo, as concepções dos jovens permitem dar conta da existência de especificidades associadas a cada contexto institucional, caracterizadas por oportunidades e constrangimentos organizacionais que influem, positiva ou negativamente, nos percursos escolares dos estudantes. (Lopes \& Costa, 2007, p. 330).

Ao longo de nossas discussões, indicamos que as inúmeras questões relacionadas à organização dos processos acadêmicos, a distribuição dos recursos e espaços acadêmicos, bem como o próprio "clima universitário" interferem, como ressaltam Lopes e Costa (idem), positiva ou negativamente na formação de nossos estudantes. Nosso objetivo aqui é cotejar essas informações de modo a caracterizar o que seria o efeito universidade, para, ao final, levantar algumas hipóteses sobre o que chamamos de efeito-turno, identificando algumas diferenças e desigualdade de oportunidades de formação entre os turnos. 


\section{2}

\section{Organização dos processos acadêmicos}

\section{2 .1}

\section{Organização institucional e corpo docente}

O principal recurso distribuído de modo desigual entre os dois turnos do curso de pedagogia são professores. Fica evidente que a maioria dos docentes efetivos opta, com alguma exceção, por lecionar no curso diurno. A justificativa entre o professorado é que a demanda da dedicação à pesquisa favorece a manutenção de suas atividades durante o dia. Entre nossos 16 entrevistados, metade ministra aulas à noite. Curiosamente, os que atuam nesta parte do dia são aqueles que não se encontram vinculados aos programas de pós-graduação da instituição.

O número de professores substitutos é sempre maior do que o de efetivos. A nova direção tem feito um esforço pra fazer esse deslocamento de chamar os professores [efetivos] pra trabalhar à noite, mas é mais difícil. [P7, professora, atua no noturno]

\footnotetext{
Uma grande parte dos professores, não todos, não está nem está aí para a graduação. Até dão boas aulas, porque são bons docentes. Ele é um bom professor, ele dá uma boa aula, mas não tem um interesse com o curso em si. Por quê? Porque não é valorizado. O que é valorizado atualmente? É a pós. É a pesquisa. [Então fica a dicotomia entre] ensino e pesquisa. Acaba sendo isso. Eu tenho certeza que se não houvesse uma obrigatoriedade de dar aula na graduação, a maior parte dos professores não ia dar aula. Você pode ver nas formaturas, pelo menos $50 \%$ (cinquenta por cento) dos professores homenageados (ou mais) são professores substitutos. E os que são professores efetivos são sempre os mesmos. [P12, gestora, atua normalmente no ensino diurno]
}

Este é um problema de gestão da universidade e não apenas da Faculdade de Educação. Todo semestre, a Faculdade de Educação precisa realizar pedido de liberação de carga horária para os inúmeros docentes contratados. No início deste semestre letivo (2014.1), houve, inclusive, um pedido do Ministério Público (MP) para cancelamento do contrato de mais de 900 docentes em situação de professor 
substituto da UERJ, que, segundo o jornal O GLOBO (12/03/2014), representam $25 \%$ do total de professores da universidade. Na ação proposta, de acordo com o jornal, o "MP alega que 'ao invés de ser exceção, a contratação temporária tornouse regra na UERJ, o que viola a ordem jurídica'. O órgão alega que esse tipo de vínculo é feito indiscriminadamente desde, pelo menos, 1994". O MP ressalta a necessidade de permanência dos docentes através de concursos públicos.

O reitor da universidade, em resposta ao Tribunal de Justiça do Rio que deferiu a liminar determinando que a UERJ não poderia mais renovar a permanência de professores substitutos, divulgou uma nota informando que não havia impedimento legal de acordo com a legislação que regulamenta a carreira docente na instituição (Lei 5343/08). O reitor garantiu que as aulas iniciariam dentro da normalidade, com todos os professores, o que de fato ocorreu.

As pesquisas sobre a educação básica mostram que as escolas de um modo geral tratam melhor os alunos de situações mais favorecidas (Brandão et al., 2005; Brandão \& Paes de Carvalho, 2011), garantido a estes estudantes professores mais experientes e motivados, uma oferta maior de cursos, e um olhar mais motivador para com este aluno. Nas instituições que atendem a grupos menos favorecidos socialmente, geralmente há o oposto, maior instabilidade entre a equipe de docentes, e com professores menos experientes.

Percebemos que para os estudantes do curso diurno, há a garantia de professores efetivos, com melhores condições de trabalho dentro da universidade, com mais experiência, especialmente acadêmica. Como vimos no relato da professora [16], não significa, em nosso caso, que estes docentes sejam motivados a lecionar na graduação, no entanto, como ela afirma, eles dão uma boa aula porque normalmente são mais experientes em sua área de estudo.

Este é, inclusive, outro fator problemático quanto aos professores substitutos. Nem sempre eles lecionam nas disciplinas de suas áreas de estudo. Apesar de recentemente ter sido implantada a seleção com provas e títulos para o professor substituto na UERJ, este realiza provas para um departamento, podendo lecionar disciplinas muito distantes de sua experiência profissional e da área em que ele realizou a prova. 
Como você faz prova (no caso dos substitutos) para um departamento, o professor substituto acaba sendo na mão do coordenador do departamento uma força de trabalho de manobra do curso. Eu não opto pelas disciplinas A, B ou C. Mesmo que eu tenha uma predileção, quem define isso é a coordenação do departamento. [P10]

Este tipo de situação pode ser o motivo, por exemplo, das reclamações de estudantes que mencionam "os professores não cumprem a ementa" [R26, estudante do noturno, oriunda do diurno]. Uma de nossas entrevistadas, agora docente efetiva, comenta sobre sua experiência enquanto professora substituta do curso.

O que eu tinha pra trabalhar como professora substituta? Uma ementa e um conjunto de bibliografia de um universo que eu desconhecia. E de possibilidades que eu também desconhecia, então eu trabalhava com os recursos que eu trazia da minha experiência docente de outro lugar, da educação básica. [P7]

A permanência na instituição de uma equipe de docentes é, portanto, importante aspecto para o desenvolvimento do trabalho de ensino acadêmico. A transitoriedade dos professores, bem como as condições precárias em que o professor substituto trabalha dificulta, por exemplo, que haja reuniões entre a equipe pedagógica da instituição, que auxilia tais professores que estão ingressando na instituição a se informar melhor sobre a proposta do curso, sobre a ementa e concepção da disciplina que irá lecionar.

A Faculdade tem seis departamentos. E cada departamento tem as suas reuniões. Agora, a grande parte das reuniões acaba sendo gasta em questões administrativas. [P1]

A gente não consegue se reunir. É outra dificuldade que a gente tem. A gente não tem reuniões pedagógicas no ensino superior. Professor concursado chega novo, ou mesmo os que são contratados. Deveria acontecer uma reunião de professores para ele ser apresentado: Professor fulano da disciplina tal, professor fulano, professor fulano. [Isso acontece] quando muito, nas reuniões de departamento. Quando muito. (...) Mas as reuniões de departamento também são raras. São raras. Normalmente quando tem algum assunto burocrático pra resolver. [P15]

Entendemos que as reuniões para planejamento e trocas de experiência sobre o curso são essenciais, tanto para desenvolver nos professores um 
sentimento de pertencimento à instituição, especialmente no caso de professores substitutos, como para deixar claros os objetivos da proposta curricular e da própria concepção do curso. Bressoux (2003), a partir de um estado da arte na área, elenca quatro características que parecem promover um clima de sucesso escolar. Deve haver, segundo o autor, um sentimento de colaboração entre a equipe da instituição educacional. A segunda característica diz respeito ao sentimento de comunidade, ou seja, de pertencimento ao grupo. Deve haver um compartilhamento entre a equipe dos objetivos da instituição, bem como ter expectativas elevadas com relação aos alunos. Por fim, a instituição precisa ser organizada, de modo a favorecer o clima da instituição.

As características apontadas pelo autor demonstram o grau de importância de se ter uma equipe que se sinta parte do grupo, coesa nas propostas da instituição, bem como ter uma organização da instituição de maneira a criar um bom clima acadêmico. Para Tardif (2008, p. 22),

\footnotetext{
uma visão clara e partilhada, a respeito do ensino e da aprendizagem, entre a equipe de formadores e os responsáveis do programa, constitui um indicador forte de uma formação que tem efeitos positivos, não somente sobre a qualidade dos futuros docentes, mas também sobre o aprendizado dos alunos que lhes são confiados (Tardif, 2008, p. 22).
}

A partir de nossos dados podemos aferir que nem mesmo o corpo docente efetivo da instituição possui essa visão clara sobre os processos de ensino do curso de pedagogia. Em conversa informal com uma professora substituta da instituição, ela comentou sobre sua reunião inicial da disciplina que lecionaria. Várias informações sobre a concepção e procedimentos do curso, que foram a ela passados - e aos demais novos colegas também contratados - pela professora efetiva responsável pela disciplina do curso, estavam equivocados do ponto de vista da proposta oficial e ela foi, aos poucos, buscando as informações nos diferentes órgãos da instituição para repassar aos seus alunos. Tardif (2008, p. 22) menciona a partir da análise de pesquisas internacionais sobre formação de professores que "não existe uma única e boa maneira de formar docentes de qualidade", mas é essencial que se tenha uma "visão clara e partilhada a respeito do ensino e da aprendizagem, visão que transparece em cada curso teórico e em cada experiência em meio de prática" (idem). Entendemos que se entre este corpo 
docente transitório, e mesmo entre os professores efetivos, não houver essa compreensão clara a respeito do profissional que se pretende formar neste curso de pedagogia, atendendo às necessidades específicas de cada grupo e turno (diurno e noturno), a formação acadêmica profissional pode se tornar fragmentada; desta forma, este futuro profissional não terá condições de exercer adequadamente sua profissão.

Os estudos sobre qualidade da educação identificam que uma boa gestão faz diferença nas instituições educacionais (Brandão et al., 2009; Paes de Carvalho e Canedo, 2012 ). O problema enfrentado pela Faculdade de Educação com relação à contratação de grande número de professores substitutos está ligado às questões de ordem de gestão institucional e política. Cabe à Faculdade administrar essa situação de modo a cuidar para que estudantes do curso noturno não sejam prejudicados em sua formação devido a estas desigualdades na distribuição dos recursos da universidade.

\section{2 .2}

\section{Alunos do curso noturno e o sentimento de discriminação}

Nossos dados indicam de um modo geral que há certo "julgamento" dos alunos do curso de pedagogia, há certa diferenciação ao tratar o aluno do curso noturno. Podemos observar o que Bourdieu (2012) chama de julgamento professoral por parte dos professores para com os estudantes do curso analisado, em especial no período noturno. Segundo Bourdieu (ibid,p. 192) "o julgamento professoral apoia-se de fato sobre todo o conjunto de critérios difusos, jamais explicitados, padronizados ou sistematizados, que lhe são oferecidos pelos trabalhos e exercícios escolares ou pela pessoa física de seu autor". Tal julgamento é, de certo modo, internalizado e inconsciente por parte dos professores.

Os estudantes do curso noturno de pedagogia se ressentem de uma certa distinção com relação aos estudantes do curso diurno, que, como ressalta 
Bourdieu, trata-se de "diferença, separação, traço distintivo" (Bourdieu, 2011, p. 18). Tais diferenças, segundo o autor, estão relacionadas ao espaço social ocupado por cada grupo numa relação de proximidade ou mesmo de distanciamento. A comparação entre um mesmo curso de pedagogia oferecido em turnos diferentes possibilitou identificar tais diferenças e separações, mesmo com um público que em muitos aspectos se assemelham, porém que possui oportunidades frequentemente bastante distintas dentro da universidade.

Um de nossos professores entrevistados concorda que os alunos do curso noturno possuem esse sentimento de discriminação. Para ele, no entanto, a diferença entre os alunos dos dois turnos está se tornando menos clara,

ainda existe, mas vai se aproximando. A diferença está mais no que a estrutura impõe. O estudante chega à noite e passa por um monte de situações, o chope, os grandes eventos que a universidade propõe na sua agenda cultural que são noturnos, não são diurnos. E eles se sentem, muitas vezes, alguns manifestam o sentimento de serem discriminados. Achar que a gente prefere a manhã que a noite. Tem um pouco de razão. Eu repito, quando estou muito incomodado eu falo: 'Esse semestre eu vou dar um tempo [de dar aulas à noite]. Vou ver se eu consigo pegar uma coisa mais tranquila, mais light, que não me incomode tanto'. [P11]

O sentimento que parece estar entre os professores é de que o aluno do curso noturno é aquele que está mais cansado, mais desinteressado nas aulas, lê menos, se dedica menos ao curso e, assim, demanda estratégias diferenciadas de trabalho do professor, maior investimento desse no planejamento de seu curso. Essa pode ser a razão pela qual muitos professores efetivos se afastam do curso noturno. Ou seja, exigiriam muito mais tempo de dedicação e mesmo trabalho na definição de estratégias didáticas mais ativas e motivadoras. No entanto como assinalamos anteriormente, a experiência transforma o cotidiano desses estudantes em participar de um "aulão avançado".

Esse juízo dos professores pode resultar numa baixa expectativa desses com relação aos estudantes do noturno, contrariando o que Bressoux (2003) encontrou como características fomentadoras de um clima acadêmico favorável aos processos de aprendizagem. Segundo o autor, as expectativas elevadas sobre os estudantes "vai conduzi-los a níveis de sucesso elevado, enquanto o nível de 
sucesso dos alunos dos quais o professor espera pouco, vai declinar" (Bressoux, 2003, p. 28).

A partir de estudos que destacaram certas regularidades de comportamentos dos professores, percebeu-se que

em comparação com os alunos pelos quais os professores têm expectativas elevadas, os alunos pelos quais os professores têm expectativas fracas geralmente assentam-se longe do professor; são tratados mais como grupos do que como indivíduos; as interações são menos calorosas (por exemplo, menos sorrisos lhes são dirigidos); recebem menos contato visual (Bressoux, 2003, p. 32).

Muitas das características discutidas pelo autor são encontradas na fala de meus estudantes. Em conversas informais com os alunos que atualmente estão estudando no curso noturno por motivo de trabalho, mas que iniciaram o curso no período diurno, eles ressentem de um descuido maior com o curso noturno. Para eles há uma menor preocupação com o estudante, as informações não chegam até eles, os professores não são efetivos, o que gera transtornos especialmente na ocasião de realização da monografia de final de curso. Há um sentimento entre os estudantes de que eles precisam correr atrás, sem muita chance para o erro. Segundo uma aluna que já está terminando o curso (está há mais de oito períodos na universidade), à noite não há muita negociação, "é aquela data, é aquele trabalho e pronto. De manhã dá para negociar com o professor.” Além disso, ela menciona que no turno da manhã os professores são mais preocupados com o aluno, querem saber por que faltaram, dão outras oportunidades caso tenham perdido alguma atividade na aula, são mais próximos a eles.

Uma estudante do noturno relatou perceber uma contradição em seu curso:

Os professores discursam que devemos ser reflexivos, escutar os nossos alunos e sempre tentar dialogar com os mesmos, tentando buscar soluções que contemplem tanto a vontade do professor quanto a vontade do aluno. Porém o que realmente acontece nas salas de aula é uma imposição do querer do professor em oposição ao querer dos alunos. Não há acordos amigáveis e sim a prevalência da decisão do professor. [R37, estudante do sétimo período do noturno]

Outro estudante narra um exemplo dessa inflexibilidade do professor em discutir sua proposta de avaliação. Ele chega a afirmar que o professor é aberto ao diálogo, 
se você conversar, pedir uma orientação mais pessoal ele é tranquilo, mas com relação ao trabalho não. Ele passou textos em espanhol e inglês para a turma [realizar seminários a partir da leitura], sendo que é uma turma de graduação. (...) Uma aluna disse que não tinha condições de ler, pediu outro material para o professor e ele falou que não tinha, só tinha esse texto em espanhol e, se vira.

[Estudante do sétimo período do noturno]

Nesse caso, o aluno relata que a colega tentou se encaixar em outro grupo cujo texto era na língua portuguesa e o professor não aceitou, porque iria aumentar o número estabelecido de alunos por grupo. Ela 'desistiu' de realizar o seminário e pediu para fazer outro trabalho. O professor ficou de ver o que ela iria fazer. Em nossa pesquisa, essa questão é oposta à verificada por Costa e Lopes (2009). Eles perceberam que os docentes do curso noturno geralmente tendiam a estabelecer um relacionamento mais próximo aos estudantes, compreendendo as questões que envolvem o ser um 'trabalhador-estudante do curso noturno, tendo uma atitude mais compreensiva com relação a estes estudantes. Em nosso estudo, os estudantes relatam certa inflexibilidade nas negociações, especialmente relativas às avaliações do curso.

Após uma entrevista, acompanhei a professora que leciona no turno da manhã até a saída da universidade. Antes, ela foi deixar um material na mecanografia e encontrou uma aluna. Ela a chamou pelo nome, abraçaram-se e conversaram. Ao final, a professora mencionou que a aluna passou por questões familiares e que quis saber como ela estava, e completou "alguns alunos gostam disso, de abraço" [P8], destacando o lugar das relações afetivas no processo de aprendizagem. Costa e Lopes (2009) identificaram que uma boa relação entre professores e estudantes é um aspecto bastante positivo na formação desses últimos. No estudo dos autores, até a memorização dos nomes dos estudantes pelos professores é importante, pois promove um sentimento de que a presença do aluno é reconhecida e cria uma sensação de "conforto e segurança, que os motiva mais para as disciplinas lecionadas" (Costa \& Lopes, 2009, p. 340). Para Bressoux (2003, p. 41), "os alunos desfavorecidos têm necessidade de mais encorajamento do que os outros".

Os alunos do noturno ressaltam sentir uma diferenciação no tratamento pelos professores em seu processo educacional. Eles sentem falta de uma relação mais próxima com esses docentes. Podemos avaliar esta questão pelo fato de 
existir esse "juízo professoral” normalmente negativo com relação às condições e possibilidades dos estudantes do curso noturno, e mesmo, uma expectativa menor com relação a estes estudantes. Neste caso, os professores tenderiam a adotar práticas mais rígidas, talvez no entendimento de que assim, esses alunos darão conta de adquirir um mínimo de conhecimentos. Tais práticas mais rígidas, no entanto, não significam processos de aprendizagem diferenciados, que poderiam motivar os estudantes para a prática de estudo.

O contraditório dessa situação é que são estes estudantes que demandariam que os docentes acreditassem neles, tendo altas expectativas sobre o desenvolvimento desses alunos, de modo a adotar um "comportamento que incentiva seus alunos a fazerem melhor e os convencendo de que eles podem se sair bem" (Bressoux, 2003, p. 55). Nos estudos sobre escolas eficazes, quando o professor cria altas expectativas para seus estudantes, ele consegue, por exemplo, adotar um ritmo rápido durante as aulas - aspecto este que foi queixa de nossos professores -, conseguindo, assim, aumentar os conteúdos trabalhados em seu curso, e, ainda, segundo Bressoux (2003), garantindo a melhora na atenção dos alunos.

Falta, portanto, que professores reconheçam a condição do aluno do curso noturno, acreditem em seu crescimento durante o curso superior e repensem estratégias de trabalho que possam contribuir para a melhor preparação desses estudantes no curso, considerando as dificuldades que este aluno traz da formação escolar e enfrenta cotidianamente. Além disso os docente precisam de um trabalho mais integrado com os outros colegas para pensarem estratégias diferencias para os problemas que surgirem.

\section{2 .3}

\section{Ensino, extensão e pesquisa}

As questões a que chamamos de efeito universidade são interligadas. O problema decorrente da gestão da instituição universitária, que mantém há anos a contratação de docentes substitutos, chegando a concentrar mais de $50 \%$ dos 
destes docentes no curso de pedagogia, como vimos, cria inúmeras dificuldades como as que já analisamos, mas interfere ainda em outro fundamento da universidade, a inextricável relação entre ensino, extensão e pesquisa.

Estudos já identificaram a problemática desta relação, na qual o ensino nas instituições universitárias, especialmente aqueles voltados à formação docente, é menos valorizados que a pesquisa. Candau (1989), a partir de estudos sobre cursos de licenciatura, já apontava para um modelo de formação universitária que destinava um lugar secundário à formação de professores, criando uma hierarquia acadêmica, onde no topo encontravam-se os profissionais que se dedicavam à pesquisa, seguidos pelos que realizavam pesquisa e ensino e depois pelos que cuidavam do ensino e da formação de professores.

Tal situação ainda hoje é comum nas universidades brasileiras, sobretudo porque as avaliações da Coordenação de Aperfeiçoamento de Pessoal de Nível Superior (CAPES) focam a produção em pesquisa dos docentes universitários, e não apenas suas atividades de ensino, como bem destacou a gestora do curso.

Para Esteves (2010, p. 47), o que "melhor distingue as formações superiores de quaisquer outras será o fato de, nas primeiras, se verificar uma aliança inextrincável entre ensino e investigação realizados, um e outra, por verdadeiras comunidades de estudantes". O fato de haver mais de 50\% de professores substitutos lecionando no curso de pedagogia, em especial, no curso noturno, como vimos, rompe essa relação entre ensino e pesquisa. Ressaltamos que não estamos questionando a formação desses docentes nem sua prática profissional, mesmo porque muitos são mestres e doutores, e de acordo com muitos estudantes, "são até melhores que professores efetivos, especialmente na didática de sala de aula" [estudante do curso noturno, $7^{\circ}$ período]. No entanto, as condições de trabalho desse profissional são bastante precárias. Ele vai para a universidade, dá sua aula e vai embora. Quando muito, fica na sala dos professores, preparando a próxima aula durante as longas "janelas" que ele possui entre uma aula e outra em seu cronograma de trabalho.

Este profissional não possui condições de desenvolver um trabalho de pesquisa junto aos estudantes, de modo a fazer a articulação entre ensino e pesquisa na universidade. Todos os professores efetivos desenvolvem seus 
projetos de pesquisa e têm condições de fazer esta articulação. Muitos oferecem bolsas de iniciação à pesquisa, de extensão, de monitoria, entre outras, de maneira a envolver os estudantes na pesquisa acadêmica. Há também estudantes voluntários que participam destes grupos. Além disso, os professores efetivos normalmente lecionam apenas as disciplinas ligadas às suas áreas de estudo, o que permite que eles realizem a conexão entre as pesquisas de seu campo de estudo e sua prática docente. Uma aluna ressalta que "o contato com professores que são importantes nas suas áreas é um ponto positivo do curso" [R7, estudante do curso diurno]. Na fala da estudante, entendemos que ser importante em sua área está ligado a essa relação entre ensino e pesquisa. $\mathrm{O}$ professor tem reconhecimento em sua área de conhecimento, e ao compartilhar seus estudos com os estudantes, contribui para a formação acadêmica deles.

Essa questão vai ao encontro de outra dificuldade encontrada pelos estudantes do curso noturno. Como somente os professores efetivos podem orientar monografias de conclusão de curso, dentro de sua área de pesquisa, os estudantes do curso noturno possuem dificuldades de encontrar professores orientadores. Como vimos, a maioria destes professores trabalha no turno diurno, logo, os estudantes do diurno conhecem esses professores, pois geralmente tiveram aula com eles, já se identificam com suas áreas de estudo, já os procuram para orientação da monografia antes mesmo de cursarem a primeira disciplina de monografia. Quando os estudantes do curso noturno procuram estes docentes, muitos já estão com a carga horária para dedicação às orientações saturadas. Duas de nossas professoras entrevistadas ressaltam que chegaram a orientar dez estudantes por semestre, mas que são exceções entre os demais docentes.

Como destaca Esteves, "temos como certo que um ensino universitário dispensado/desligado da investigação e seu mero consumidor passivo tende a não ser mais do que um ensino secundário avançado" (Esteves, 2010, p. 47). Por tal razão, compreendemos que os estudantes do curso noturno saem prejudicados com a diferenciação entre a oferta de recursos que a eles são destinados, como a possibilidade de criação de um ambiente incentivador de estudo e de pesquisa. Por mais que estes estudantes não tenham as condições ideais para se dedicarem aos estudos, ou mesmo ingressarem nos projetos de estudos dos professores, o convívio com docentes que incentivem práticas de investigação e que coloquem 
seus alunos "em contato direto e pessoal com a cultura geral e científica própria do campo educativo e da pesquisa em ciências sociais e humanas e em ciências da educação (Tardif, 2008, p. 40)" contribuirá para a formação intelectual e dos conhecimentos teóricos essenciais à profissão docente, bem como de uma postura de pesquisa desses estudantes.

\section{2 .4}

\section{Articulação entre universidade e escola de educação básica}

A literatura sobre formação de professores enfatiza a parceria entre a universidade e a escola de educação básica como importante caminho na preparação de docentes (Foerste, 2004; Guimarães, 2008; Canário, 2007; Nóvoa, 2007; Tardif, 2008; Perrenoud, 1999). Ao discutir a melhor preparação do futuro professor por meio do estágio supervisionado, minha investigação no mestrado realçou a relevância da relação entre estas duas instituições de ensino na preparação docente, de modo a articular teoria e prática neste processo de formação. (Rodrigues, 2009; 2010; 2012)

Os estudantes em tela mencionaram exatamente a falta que sentem em seu curso da relação entre a teoria estudada e a prática profissional para a qual estão se preparando, evidenciando, pois, a ausência do desenvolvimento de parcerias entre universidade e escola.

Sinto muita falta em ter experiências que envolvam mais a prática no cotidiano escolar, o que é essencial para uma boa atuação profissional. [R16, estudante do diurno].

Falta mais prática no curso, principalmente para quem não fez curso médio normal. [R35, estudante do noturno]

Apesar de o estágio ajudar a ver como é a sala de aula, acho que visitas a diferentes escolas [de modo] a conhecer suas realidades, ajudaria. [R20, estudante do diurno]

Tive muitas dificuldades e decepções com professores que não conheciam praticamente nada sobre o conteúdo das disciplinas que ministravam e outros que não haviam tido nenhum contato com a escola básica, o que acabava separando a teoria do que acontece na prática. [R2, estudante do oitavo período do noturno, originária do diurno]. 
Independentemente dos excelentes conhecimentos que construímos e debatemos, não somos preparados para exercer a docência. A universidade não nos prepara de forma alguma para dar aula ou encarar uma turma, seja de educação infantil ou de fundamental I; muito menos nos prepara para a coordenação pedagógica. [R23, estudante do noturno].

Os relatos acima, além de destacarem o desejo de maior relação entre teoria e prática, considerando-a como fundamental para a atuação profissional, tocam em outras questões que permeiam essa relação. Primeiro, a falta da vivência da prática escolar por estudantes que não fizeram ensino médio normal. Segundo, as poucas possibilidades de visitas a diferentes instituições escolares durante o curso, atividade geralmente reservada apenas para os estágios. Em terceiro, a falta de conhecimento dos professores universitários sobre as práticas escolares, já que a maioria nunca passou por este nível de ensino, ou, se passaram, isso ocorreu há muito tempo atrás. Por fim, a última estudante, que cursou ensino médio normal e atua como professora, avalia seu curso, ressaltando que esse não dá conta nem da formação do professor, nem do pedagogo, como a atuação na área de coordenação pedagógica.

Há tempos a comunidade educacional vem discutindo esse que é considerado o principal problema da formação de professores, o gap existente entre universidade e escola. Candau (1989) destacou que um dos problemas se dava pelo fato de parte dos professores universitários não possuir, em geral, qualquer vivência neste nível de ensino. Por tal razão, os estudos apontam a necessidade da criação de parcerias fortes entre estas duas instituições de ensino ressaltam que elas possibilitariam que o estudante tivesse condições de vivenciar o ambiente escolar durante a sua formação, com acompanhamento de um professor experiente da prática. Neste caso, as duas instituições de ensino participariam efetivamente da formação profissional deste aluno.

Por outro lado, nossos dados indicam que aqueles estudantes que passaram pelo ensino médio normal ou que já atuam como professores parecem possuir melhores condições de fazerem essa articulação entre teoria e prática, haja vista alguma experiência da sala de aula obtida previamente. Os demais estudantes demandariam, por conseguinte, estratégias formativas que os possibilitasse vivenciar melhor o ambiente escolar. 
Entendemos que as estratégias pedagógicas de trabalho com estes estudantes de pedagogia se beneficiariam da articulação entre os conceitos teóricos e a prática de sala de aula, ambos fundamentais à prática profissional do professor.

Mesmo que as visitas escolares promovidas durante o horário das aulas constituem uma relevante estratégia, essas ficam restritas aos estudantes do curso diurno. Por sinal, durante minha graduação na mesma universidade em pauta, a professora de estágio montou um cronograma de visitas a diferentes instituições com propostas educacionais bastante variadas, o que foi bastante enriquecedor a nós estudantes, especialmente porque éramos acompanhados por ela, que nos ajudava a realizar algumas observações e questionamentos. Tais propostas poderiam ser desenvolvidas semelhantemente com alunos do curso noturno, com dias programados, de modo que cada estudante pudesse se organizar durante o semestre para tais atividades práticas.

Outra estratégia seria aproveitar melhor a experiência deste estudante a ponto de trazê-la para as discussões das aulas. Relembro que cerca de $60 \%$ dos estudantes que trabalham, de ambos os turnos, o fazem como professores ou na área de educação, e se beneficiariam, portanto, de uma formação que dialogasse com sua prática profissional cotidiana, ao discutir na universidade os problemas por eles enfrentados no dia a dia da escola. Essa articulação entre os conhecimentos da universidade e da escola possibilitaria também que muitos estudantes considerassem a docência como opção profissional. Minha experiência enquanto estudante de pedagogia serve como exemplo. Fui "cooptada", para usar o termo de nossos professores entrevistados, para a docência a partir de uma experiência bem sucedida de estágio na educação infantil. Durante a graduação, tive uma professora de estágio que conseguiu realizar essa articulação entre esses dois espaços de formação, de maneira a possibilitar que eu vivenciasse mais de perto a experiência da prática docente, o que me levou a decidir pela profissão de professora, na qual atuo.

Uma de nossas entrevistadas recorda sua formação no curso normal, sugerindo essa articulação.

Eu acho que psicologia da educação tinha que ser como eu estudei no curso normal. Ah, vamos fazer observação, acompanhar o desenvolvimento pedagógico de uma criança, psicológico, como é que ele evoluiu. Vamos ver se o que Piaget diz funciona, se o que Vygotsky diz funciona (...) Além de ser um ano inteiro, a 
gente tinha que, no nosso estágio, escolher uma criança e observar esta criança o ano inteirinho, e fazer registros da aprendizagem dessa criança. Além do estágio de prática de ensino. Existe isso hoje? A escola da vida e a vida da escola são completamente diferentes. Eu acho que esse curso normal da minha geração não tem comparação com a pedagogia de hoje ${ }^{7}$.

Essa professora ainda destaca que os estudantes de pedagogia "detestam" o curso de psicologia da educação, por se tratar de um curso completamente desvinculado da realidade por ele discutida. Contrapondo à experiência por ela vivenciada, a professora ainda menciona que em seu curso de psicologia da educação no ensino médio normal "era tudo acompanhando, quer dizer, não era decoreba só não". Essa estratégia de trabalho possibilitava a discussão de casos reais, de situações reais que seriam vivenciadas pelos futuros docentes, e, que em nosso caso, iria trazer benefícios tanto aos estudantes que estão na prática de sala de aula, ou na área da educação, como àqueles que apesar de cursarem pedagogia na expectativa de atuarem em outras áreas, tivessem uma oportunidade de conhecer melhor a profissão de professor. A articulação entre teoria e prática, que sempre esteve em destaque nas discussões sobre formação de professores, é, sem dúvida, um "gargalo" da área. Para Nóvoa (2002, p. 29) tal articulação deve ser enfrentada com a consequência de que "trabalhar e formar não sejam atividades distintas". Em estudo realizado com professoras-estudantes, ou seja, professoras que estavam cursando o ensino superior, Santos e Dias (2012) identificaram que para elas o curso possibilitou um repensar de sua prática profissional, entretanto, os estágios não foram de grande valia devido a sua tradicional organização.

Roldão (2007) enfatiza a necessidade de se garantir a qualidade científica na formação profissional de docentes, de forma que o professor assegure uma especificidade no saber de sua área. A autora reforça que cabe à formação centrarse na ação profissional, a fim de organizar o curso "em torno da sua função e do saber necessário ao desempenho profissional" (Roldão, 2007, p. 40). Para tanto, considero ser fundamental efetivar esta relação entre a teoria e a prática a partir da articulação entre as vivências da escola e as discussões teóricas fomentadas pela

\footnotetext{
${ }^{7}$ Muitos professores que realizaram a formação de professores no ensino médio normal tendem a fazer esta comparação entre curso normal e curso de pedagogia. Cruz (2011) realiza esta discussão ao entrevistar professores de pedagogia que se formaram no curso entre as décadas de 1930 e 1960. Todos, na ocasião, já mencionavam que entendiam que a formação que tiveram no curso normal era mais sólida em comparação ao curso de pedagogia por eles vivenciado.
} 
universidade, transformando situações de trabalho em situações de formação (Canário, 2001). Para Roldão (2007, p. 37), a articulação entre os saberes pedagógicos e científicos promoveria uma "sólida construção de um saber científico-profissional integrador de todos os saberes que se mobilizam para a prática da ação de ensinar enquanto fazer aprender alguma coisa a alguém”. Aspecto este essencial à formação docente.

Em nosso entendimento, "é a profissão que deve servir de base à formação e não, por exemplo, as disciplinas, os módulos ou os campos de conhecimento" (Tardif, 2008, p. 31). Destarte, a prática profissional se elege como a base da formação. 


\section{Considerações finais}

Há escassa produção de conhecimento/pesquisa dedicada a analisar as questões gerais e mais específicas dos cursos superiores noturnos, uma escassez que se amplia quando se trata de comparar as peculiaridades do mesmo curso em diferentes turnos. A realização de tais estudos permitiria identificar as possíveis dificuldades dentro da proposta de formação, bem como as estratégias desenvolvidas com cada grupo, de forma a atender às especificidades na formação dos estudantes dos dois turnos. De modo geral, a partir do conhecimento disponível e de estudos de alguns cursos específicos, há certo consenso de que normalmente os turnos noturnos recebem alunos de nível social mais baixo e que possuem menores condições de se dedicarem à formação universitária. Esses resultados, entretanto, não são suficientes para a formulação de generalizações.

Nossa pesquisa constata a existência de posições divergentes sobre as vantagens (maturidade dos alunos, experiência profissional) e as desvantagens (condições precárias para a dedicação ao estudo, dupla jornada de trabalho e de estudo, etc.) dos estudantes de curso noturno. Um dos maiores problemas e diferenças estariam, nas desigualdades de estrutura e organização institucional e acadêmica no curso de pedagogia, objeto desta pesquisa, o que designamos como efeito universidade. Identificamos algumas diferenças relativas às desigualdades de oportunidades de formação nos dois turnos, o que consideramos como efeito turno. Como se trata de estudo de caso, destaco, todavia, que esta pesquisa também não permite generalizações, mas apresenta indícios que mereceriam maiores investigações em outros cursos e instituições.

A Lei de Diretrizes e Bases da Educação, em capítulo que versa sobre a educação superior, no artigo 47, parágrafo quarto, garante que "as instituições de educação superior oferecerão, no período noturno, cursos de graduação nos mesmos padrões de qualidade mantidos no período diurno, sendo obrigatória a oferta noturna nas instituições públicas, garantida a necessária previsão orçamentária” (Brasil, 1996). 
Observamos, contudo, que na instituição analisada há distribuição desigual dos recursos e espaços da universidade para os estudantes do noturno: os horários de atendimento dos serviços e das aulas são reduzidos; a maioria dos eventos acadêmicos ocorre durante o dia; as disciplinas eletivas que parecem ser de maior interesse dos estudantes são ofertadas também no diurno; entre outros aspectos. Ainda assim, o maior problema encontrado está na distribuição desigual de professores entre as disciplinas e turnos. Pelo fato de o curso de pedagogia analisado ser um dos maiores no estado do Rio de Janeiro, o corpo docente efetivo do curso tem dificuldade em atendê-lo de modo pleno, lecionando todas as disciplinas oferecidas nos dois turnos. Esse é, inclusive, um problema geral da universidade, a qual, como já exposto, contrata anualmente cerca de 1/3 do número de seus docentes na condição de professores substitutos.

Tais professores, em situação precária de trabalho em função do status temporário de sua atuação, são alocados geralmente no turno da noite. A precariedade se verifica ainda na carência de espaço de trabalho definido na instituição, na usual ausência às reuniões de planejamento do curso, bem como na falta de condições de interações formais com os pares, sem mencionar os baixos salários pagos a esta categoria. Além disso, eles são locados nas disciplinas em razão das necessidades de se preencher espaços didáticos muitas vezes sem relação com sua área de especialização. Professores substitutos ainda não podem orientar as monografias de final de curso, o que acarreta dificuldades crescentes aos alunos do turno noturno de encontrar orientadores.

Os estudantes, além das já mencionadas dificuldades de se conseguir orientação por parte dos docentes efetivos e das poucas opções de disciplinas optativas, lidam também com a escassa flexibilidade na organização curricular. Com muitas disciplinas por semestre, mais os estágios curriculares, torna-se mais difícil a quem estuda dar conta de concluir seu curso no tempo mínimo previsto. Esses estudantes se ressentem também de uma aproximação dos professores e de maior abertura para negociação dos processos acadêmicos, como as avaliações.

A desarticulação entre teoria e prática, problema crônico na área de formação de professores, apresenta-se como problemática adicional à formação desses alunos, especialmente aqueles que estão longe das atividades de docência na educação básica. Sozinhos, eles enfrentam o desafio de fazer a necessária 
articulação entre as reflexões teóricas e a realidade de sua profissão, sobretudo pelas poucas oportunidades de vivência prática orientada que o curso oferece. Os estágios, cumpridos usualmente como atividades burocráticas, sem uma orientação mais próxima da universidade por meio de programas de acompanhamento deste estudante, são deixados para o final do curso e pouco contribuem para oferecer a estes futuros professores um ambiente propício à experimentação de sua prática profissional.

Aliados a este aspecto, se encontram o desconhecimento e a falta de condições de os professores relacionarem as questões abordadas pelas disciplinas à experiência de magistério dos alunos. Nossos dados indicaram que mais da metade dos estudantes dos dois turnos trabalha ou faz estágios na área de educação; logo, a experiência profissional deles poderia ser valorizada e trazida para a sala de aula. Tal estratégia pedagógica proporcionaria uma formação com maior diálogo entre teoria e prática, além de motivar a profissão de professor nestes estudantes. Com experiências mais próximas do campo profissional, todos os estudantes, mesmo aqueles mais distantes da escola, se beneficiariam com exemplos da prática de sala de aula sendo articulados à teoria estudada.

Apesar de todas as dificuldades enfrentadas durante a experiência acadêmica, para quem tem baixo capital escolar, a vivência universitária traz um ganho para a vida destes estudantes, significando uma ampliação da estrutura de capitais (capital simbólico, cultural/escolar) com repercussão na trajetória social, em especial nas condições profissionais.

A universidade, por sua vez, precisa atentar para que a organização dos processos institucionais e acadêmicos ofereça oportunidades iguais a todos os alunos, independentemente de seus horários de estudo. Além disso, espera-se desta instituição de ensino o cumprimento de seu papel como fomentadora de um "clima universitário" que se traduza em um ambiente favorecedor de atividades acadêmicas, culturais e sociais para seus estudantes.

Destacamos, por fim, o caráter exploratório e preliminar da presente pesquisa, circunscrita à comparação entre os cursos diurno e noturno de formação de professores, disponível aos estudantes de pedagogia. Sugerimos a realização de mais estudos sobre os problemas dos atuais cursos de pedagogia, destinados especificamente às características diferenciais dos cursos diurno e noturno no nível superior, buscando identificar, assim como esta tese verificou, se haveria tais 
diferenciações na oferta de oportunidade nas condições de formação em outros contextos. 


\section{Referências bibliográficas}

ALVES, Maria \& SOARES, José Francisco. Efeito-escola e estratificação escolar: o impacto da composição de turmas por nível de habilidade dos alunos. Educ. rev. [online]. 2007, n.45, pp. 25-59.

ANDRADE, Renato Júdice de; SOARES, José Francisco. O efeito da escola brasileira. Estudos em Avaliação Educacional, São Paulo, v. 19, n. 41, p. 379406, 2008.

BOURDIEU, P. A distinção: crítica social do julgamento. Porto Alegre, RS: Zouk, 2006.

BOURDIEU, P. Coisas ditas. Trad. Cássia R. da Silveira e Denise Moreno Pegorim. São Paulo: Brasiliense, 2004.

BOURDIEU, P. Escritos de educação. Seleção, organização, introdução e notas de Maria Alice Nogueira e Afrânio Catani. 13ª ed. Petrópolis: Vozes, 2012.

BOURDIEU, P. Razões práticas: sobre a teoria da ação. $11^{\mathrm{a}} \mathrm{ed}$. Trad. Mariza Corrêa. Campinas: Papirus, 2011.

BOURDIEU, P; PASSERON, J. C. A reprodução. Elementos para uma teoria do sistema de ensino. Rio de Janeiro: Francisco Alves, 1975.

BOURDIEU, Pierre \& PASSERON, Jean-Claude. O tempo e o espaço no mundo estudantil. Tad. Narciso Teixeira e Luís Cláudio Figueiredo. In: BRITO, Sulamita (org.). Sociologia da juventude, IV - Movimentos juvenis. Rio de Janeiro: Editora Zahar, 1968.

BOURDIEU, Pierre. A ilusão bibliográfica. In: FERREIRA, Marieta de Moraes \& AMADO, Janaina (org.). Usos e abusos da História Oral. Rio de Janeiro: FGV, 1996, p. 183-191.

BRANDÃO, Z. Operando com conceitos: com e para além de Bourdieu. Educação e Pesquisa (USP. Impresso), v. 36, p. 227-241, 2010.

BRANDAO, Zaia e CARVALHO, Cynthia Paes de. Processos de produção das elites escolares. Educ. Soc. [online]. 2011, vol.32, n.115, pp. 507-522 .

BRANDÃO, Zaia. Cursos de pedagogia - estudos de caso e desafios à produção de qualidade do ensino fundamental. Projeto de Pesquisa, CNPq, 2011. 
BRANDAO, Zaia; MANDELERT, Diana and PAULA, Lucília de. A circularidade virtuosa: investigação sobre duas escolas no Rio de Janeiro. Cad. Pesquisa. [online]. 2005, vol.35, n.126, pp. 747-758 .

BRASIL. Conselho Nacional de Educação. Resolução $n^{\circ}$ 1/2006. Diretrizes curriculares de Pedagogia. Diário Oficial da União, no 92, seção 1, p. 11-12, 16 de maio de 2006.

BRASIL. Lei $\mathrm{n}^{\circ}$ 9.394, de 20 de dezembro de 1996. Lei de diretrizes e bases da educação Nacional. Brasília: Casa Civil da Presidência da República Federativa do 51 Brasil/Subsecretaria para Assuntos Jurídicos, 1996. Disponível em: <http://www.planalto.gov.br/ccivil_03/Leis/L9394.htm>. Acesso em 23, set.,2013.

BRESSOUX, Pascal. As pesquisas sobre o efeito-escola e o efeito professor. Educação em Revista, Belo Horizonte, n. 38, dez. 2003. p. 17-88.

BRITO, Márcia. ENADE 2005: Perfil, desempenho e razão da opção dos estudantes pelas licenciaturas. Avaliação, Campinas; Sorocaba, SP, v. 12, n. 3, p. 401-443, set. 2007.

BROOKE, Nigel \& SOARES, José (orgs). Pesquisa em eficácia escolar: origem e trajetórias. Belo Horizonte: Editora UFMG, 2008.

CANÁRIO, Rui. A escola tem futuro? Das promessas às incertezas. Porto Alegre: Artmed, 2006.

CANÁRIO, Rui. A prática profissional na formação de professores. In: PAIVA, Bartolo. Formação profissional de professores no ensino superior. Porto: Porto Editora, 2001, p. 31-45.

CANÁRIO, Rui. Formação e desenvolvimento profissional dos professores. Comunicações da conferência: desenvolvimento profissional de professores para a qualidade e para a equidade da aprendizagem ao longo da vida. Portugal: Presidência Portuguesa do Conselho da União Européia, 2007, p. 68-81. Disponível em: <http://d.scribd.com/docs/1k5w5s3n5dkfovkuc1v1.pdf> Acesso em $15 / 01 / 2013$.

CANDAU, Vera. Novos rumos da licenciatura. Pesquisa. Brasília: INEP/PUCRio, 1988.

CARRANO, Paulo. Jovens Universitários: acesso, formação, experiências e inserção profissional. In: SPOSITO, M. (coord.). Estado da Arte sobre juventude na pós-graduação brasileira: educação, ciências sociais e serviço social (1999-2006), volume 1. Belo Horizonte, MG: Argvmentvm, 2009.

CARVALHO, Wirla. Da alvorada ao acaso. Estudo de caso da avaliação da aprendizagem em cursos de pedagogia diurno e noturno em uma instituição de ensino superior pública. Dissertação de mestrado, Universidade do Ceará FACED, Fortaleza: 2012.

CAZELLI, S. Ciência, cultura, museus, jovens e escolas: quais as relações? 
Tese - Departamento de Educação - PUC-Rio, 2005.

CHARLOT, Bernard. Relação com o saber, formação de professores e globalização: questões para a educação hoje. Porto Alegre, Artmed, 2005.

COLLINS, Randhal, Estratificação situacional: uma teoria micro-macro da desigualdade. Trad.: Ralph Ings Bannell. Boletim Soced, 2008, v. 6. Disponível em: http://www.maxwell.lambda.ele.puc-rio.br/soced.php?strSecao=input.

COMIN, Álvaro \& BARBOSA, Rogério. Trabalhar para estudar: sobre pertinência da noção de transição escola-trabalho no Brasil. Novos Estudos, n.9, Nov. 2011. p. $75-95$.

COSTA, Marcio da \& KOSLINSKI, Mariane C.. Prestígio escolar e composição de turmas: explorando a hierarquia em redes escolares. Est. Aval. Educ. [online]. 2008, vol.19, n.40 [citado 2014-05-17], pp. 305-330.

COULON, Alain. A condição de estudante: a entrada na vida universitária. Trad. Georgina dos Santos e Sônia Sampaio. Bahia: EDUFBA, 2008.

CRAHAY, Marcel. Poderá a escola ser justa e eficaz? Da igualdade das oportunidades à igualdade dos conhecimentos. Tradução de Vasco Farinha. Lisboa: Instituto Piaget, 2002. (Horizontes Pedagógicos, 92). [Original 2000]

CRUZ, Giseli. Curso de pedagogia no Brasil: história e formação com pedagogos primordiais. Rio de Janeiro: Wak Editora, 2011.

DIAS, Talita.; et al. Cursos diurnos e noturnos: fatores de aprovação no vestibular da UFMG. Cadernos de Pesquisa, v. 38. n. 133, p. 127-146, jan./abr. 2009.

ELIAS, Norbert. A sociedade dos indivíduos. Rio de Janeiro: Jorge Zahar Editor, 1994.

ESTEVES, Manuela. Para a excelência pedagógica do ensino superior. Sísifo: Revista de Ciências da educação, nº 7, set./dez. 2008.

FACULDADE DE EDUCAÇÃO. Programa UERJ de formação de professores para a educação básica: a reformulação do curso de pedagogia da Faculdade de Educação. UERJ: Rio de Janeiro, setembro de 2002.

FALDINI, et al. Comparação do perfil de alunos do curso de engenharia química dos períodos diurno e noturno de uma escola particular. São Paulo, BRAZIL: Anais: International Conference on Engineering and Computer Education, mar, $16-19,2003$.

FERLIN, Edson \& TOZZI, Marcos. Turno diurno x noturno: um estudo de caso na engenharia da computação. Anais: XXXIII - Congresso Brasileiro de Ensino de Engenharia, 2005. Disponível em: http://www.abenge.org.br/ CobengeAnteriores /2005/artigos/PR-1-72877480968-111756969 3013.pdf 
FOERSTE, Erineu. Parceria na formação de professores. São Paulo: Cortez, 2005.

FRANCO, Creso et al. Qualidade e eqüidade em educação: reconsiderando o significado de "fatores intra-escolares". Ensaio: aval.pol.públ.Educ. [online]. 2007, vol.15, n.55 [cited 2014-05-17], pp. 277-298 .

GATTI, B.; BARRETO, Elza.; coords. A atratividade da carreira docente no Brasil. São Paulo: Fundação Victor Civita e Fundação Carlos Chagas, 2009.

GATTI, B.; NUNES, coords. Relatório final: estudo dos cursos de licenciatura no Brasil: letras, matemática e ciências biológicas. Rio de Janeiro: Fundação Carlos Chagas, 2008.

GATTI, Bernadete Angelina e BARRETO, Elba Siqueira de Sá (Coord). Professores do Brasil: impasses e desafios. Brasília: UNESCO, 2009.

GATTI, Bernardete. Formação de professores no Brasil: características e problemas. Educ. Soc., Campinas, v. 31, n. 113, p. 1355-1379, out.-dez, 2010.

GATTI, Bernardete; BARRETO, Elba \& ANDRÉ, Marli. Políticas docentes no Brasil: um estado da arte. Brasília: UNESCO, 2011.

GIMENES, Diesse G; PULLIN, Elsa M.M.P. Estratégias de leitura utilizadas por licenciandos de áreas distintas para lerem textos de estudo. Semina: Ciências Sociais e Humanas, Londrina, v. 31, n. 1, p. 111-121, 2010. Disponível em: <http://www.uel.br/revistas/uel/index.php/seminasoc /article/view/8653/8491>. Acesso em: 9 mar. 2012.

GOMES, Candido. A escola de qualidade para todos: abrindo as camadas da cebola. Ensaio: Avaliação em políticas públicas. Rio de Janeiro, v. 13, n. 48, p. 281-306, jul./set. 2005.

GUIMARÃES, Valter. Parceria entre instituições formadoras e escolas na formação de novos professores - perspectivas e recomendações de cautela. In: XIV Encontro Nacional de Didática e Prática de Ensino, Porto Alegre: Anais do XIV ENDIPE, 2008. p. 683-701.

LEITE, Carlinda (org). Sentidos da pedagogia no ensino superior. Porto: Legis Editora, 2010. (Coleção Ciências da Educação)

LIEBERMAN, Ann. "Real-life view: An interview with Ann Lieberman", Journal of Staff Development, vol. 20, $\mathrm{n}^{\circ}$ 4, 1999. Disponível em: http://www.pps.k12.or.us/files/district-eadership/Read_Life__ View An_Interview_with_Ann_Lieberman_Dennis_Sparks.pdf

LOPES, João; COSTA, António. Os estudantes e os seus trajectos no Ensino Superior: Sucesso e Insucesso, Factores e Processos, Promoção de Boas Práticas, Relatório final de Pesquisa, Portugal: 2009.

MELLO, Guiomar. e REGO, T. C. Formação de professores na América Latina e no Caribe: a busca por inovação e eficiência. In: Ofício de Professor na América Latina 
e Caribe: Trabalhos apresentados na Conferência Regional O Desempenho dos Professores na América Latina e no Caribe, Novas Prioridades, Brasília, julho de 2002. São Paulo: Fundação Victor Civita; Brasília: UNESCO, Brasília, 2004.

MENEZES-FILHO, N. e RIBEIRO, F. Os determinantes da melhoria do rendimento escolar. Em: VELOSO, Fernando.; et al. Educação Básica no Brasil: construindo um país do futuro. Rio de Janeiro: Elsevier, 2009.

MINISTÉRIO DA EDUCAÇÃO. Comunicações da conferência: desenvolvimento profissional de professores para a qualidade e para a equidade da aprendizagem ao longo da vida. Portugal: Presidência Portuguesa do Conselho da União Européia, 2007, p. 21-28.

NERI, Marcelo. O paradoxo da evasão e as motivações dos sem escola. In: VELOSO, Fernando.; et al. Educação Básica no Brasil: construindo um país do futuro. Rio de Janeiro: Elsevier, 2009.

NOGUEIRA, Cláudio Marques Martins. \& NOGUEIRA, Maria Alice. A sociologia da educação de Pierre Bourdieu: limites e contribuições. Educação e Sociedade, ano XXIII, n. 78, Abril, 2002.

NÓVOA, António. O regresso dos professores. Comunicações da conferência: Desenvolvimento profissional de professores para a qualidade e para a equidade da aprendizagem ao longo da vida. Portugal: Presidência Portuguesa do Conselho da União Européia, 2007, p. 21-28.

NUNES, Edson (org.). Educação superior no Brasil: estudos, debates, controvérsias. Rio de Janeiro: Garamond, 2012.

O GLOBO. Apesar de proibição da Justiça, Uerj renova com professores substitutos. Disponível em: http://oglobo.globo.com/sociedade/educacao/apesarde-proibicao-da-justica-uerj-renova-com-professores-substitutos-11858145.

Acesso em 17/03/14.

OLIVEIRA, Romualdo. Da universalização do ensino fundamental ao desafio da qualidade: uma análise histórica. Educ. Soc., Campinas, vol. 28, n. 100 Especial, p. 661-690, out. 2007.

PAES DE CARVALHO, Cynthia. ; CANEDO, M. L. . Estilos de Gestão, Cultura Organizacional e Qualidade de Ensino. Educação e Cultura Contemporânea, v. 9, p. 78-98, 2012. PEIXOTO, Maria. Ampliação da oferta de cursos noturnos estudos comparativos: cursos diurnos e noturnos. Relatório. UFMG - Diretoria de avaliação institucional: 2004.

PEREIRA, Luiz. O magistério primário numa sociedade de classes. São Paulo: Livraria Pioneira Editora, 1969.

PERRENOUD, Philippe. Formar professores em contextos sociais em mudança: prática reflexiva e participação crítica. Revista Brasileira de Educação. n. 12, set-dez, 1999. p. 5-21. 
PERRENOUD, Philippe. Formar professores em contextos sociais em mudança: prática reflexiva e participação crítica. Revista Brasileira de Educação. n. 12, set-dez, 1999. p. 5-21.

RODRIGUES, Priscila Andrade Magalhães. Anatomia e fisiologia de um estágio. Dissertação de Mestrado - Departamento de Educação, Pontifícia Universidade Católica do Rio de Janeiro, 2009.

RODRIGUES, Priscila Andrade Magalhães; Lüdke, Menga. O estágio como porta de entrada para o trabalho docente. In: CORDEIRO, A.; HOBOLD, M.; AGUIAR, M. (orgs.). Trabalho docente: formação, práticas e pesquisa. Joinville: Editora Univille, 2010, p. 29-46.

RODRIGUES, Priscila Andrade Magalhães. Uma proposta de colaboração entre universidade e escola na formação de professores através do estágio supervisionado. In: RODRIGUES, Priscila Andrade Magalhães et al. (orgs.). Escritos de pesquisa: educação, seus atores e instituições. Curitiba: Editora CRV, 2012.

ROLDÃO, Maria do Céu. Formar para a excelência profissional — pressupostos e rupturas nos níveis iniciais da docência. Educação e Linguagem, ano 10, v. 1, n. 15, São Bernardo do Campo, SP: UMESP, pp. 18-42, jan-jun. 2007. p. 18-42.

RUIZ, Valdete. Estratégias motivacionais: estudo exploratório com universitários de um curso noturno de administração. Psicologia Escolar e Educacional, Volume 8, Número 2, 167-177, 2004.

SANTOS, Lucíola \& DIAS, Regina. Trajetórias escolares e prática profissional de docente das camadas populares. Revista Brasileira de Educação, v. 18, n. 52, jan./mar. 2003.

SETTON, M.G.J. A divisão interna do campo universitário: uma tentativa de classificação. Revista Brasileira de Estudos Pedagógicos, Brasília, DF, v. 80, n. 196, p. 451-471, set./dez. 1999.

SETTON, Maria da Graça Jacintho. Um novo capital cultural: pré-disposições e disposições à cultura informal nos segmentos com baixa escolaridade. Educ. Soc. [online]. 2005, vol.26, n.90, pp. 77-105.

SILVA, Nelson \& BARBOSA, Maria Ligia. Desempenho individual e organização escolar na realização educacional. Sociologia\&antropologia, v.02.04: 159-184, 2012.

SOUZA, Alberto \& SILVA, Gabriel. Considerações sobre a importância da turma no desempenho dos alunos em escolas municipais. REICE - Revista Electrónica Iberoamericana sobre Calidad, Eficacia y Cambio en Educación, 2007, Vol. 5, No. 2e.

SPOSITO, Marilia Pontes (coord.). Juventude e escolarização (1980/1998), Série Estado do conhecimento, número 7, Brasília, MEC/INEP, Comped, 2002. 
TARDIF, M. Princípios para guiar a aplicação dos programas de formação inicial para o ensino. Anais do XIV ENDIPE, Porto Alegre: EDIPUCRS, 2008. v. 1. p. $17-46$.

TINTO, Vincent. Student retention and graduation: facing the truth, living with the consequences. Occasional Paper, Washington, DC: The Pell Institute, 2004.

UERJ. Ementário. Disponível em: http://www.ementario.uerj. $\mathrm{br} /$ cursos/pedagogia.html.

VANDENBERGHE, Frédéric. "O real é relacional": uma análise epistemológica do estruturalismo gerativo de Pierre Bourdieu. Trad. Gabriel Peters. S.E.: S.D.

VARGAS, Hustana; PAULA, Maria. A inclusão do estudante-trabalhador e do trabalhador-estudante na educação superior: desafio público a ser enfrentado. Avaliação, Campinas; Sorocaba, SP, v. 18, n. 2, p.459-485, jul. 2013.

VELOSO, Fernando.; et al. Educação Básica no Brasil: construindo um país do futuro. Rio de Janeiro: Elsevier, 2009.

VIANA, José. Et al. Curso noturno de licenciatura em química - uma década de experiência na UFMS. QUÍMICA NOVA, 20(2) 212 - 218, 1999.

ZAGO, N. Do acesso à permanência no ensino superior: percursos de estudantes universitários de camadas populares. Revista Brasileira de Educação, São Paulo, v. 11, n. 32, p. 226-237, 2006.

ZAGO, Nadir. A condição do estudante: um estudo sobre o acesso ao ensino superior. Anais do XII Congresso Brasileiro de Sociologia. Belo Horizonte, maio - jun, 2005. |link para este trabalho|

ZANARDI, Maria \& LIMA, João. Aprendizado de Cálculo Diferencial e Integral II: curso noturno versus curso diurno integral na FEG/UNESP. Anais do CNMAC, v. 2, 2010. Disponível em: http://www.sbmac.org.br/eventos/ cnmac/xxxiii_cnmac/pdf/690.pdf. Acesso em 22/09/2013. 


\section{ANEXOS}

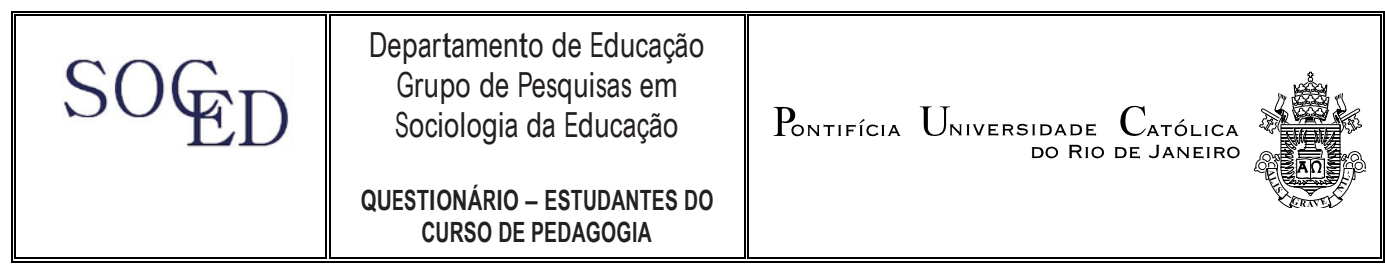

\section{Prezado estudante,}

O Grupo de Pesquisa em Sociologia da Educação (SOCED / PUC-Rio) está desenvolvendo a pesquisa Cursos de pedagogia estudos de caso e desafios à produção de qualidade do ensino fundamental que tem por objetivo avaliar características de alguns cursos de pedagogia em universidades do Rio de Janeiro, e levantar subsídios para pensar estratégias visando a melhoria da qualidade da escola pública.

Nesta etapa do estudo queremos ouvir sua opinião sobre o curso, suas condições para se dedicar ao estudo e também conhecer o perfil socioeconômico e cultural do estudante que cursa pedagogia.

As respostas a cada questionário serão trabalhadas coletivamente, garantindo assim, o sigilo de cada participante.

Obrigada por sua colaboração,

Zaia Brandão

Professora Titular da PUC-Rio Coordenadora do SOCED 


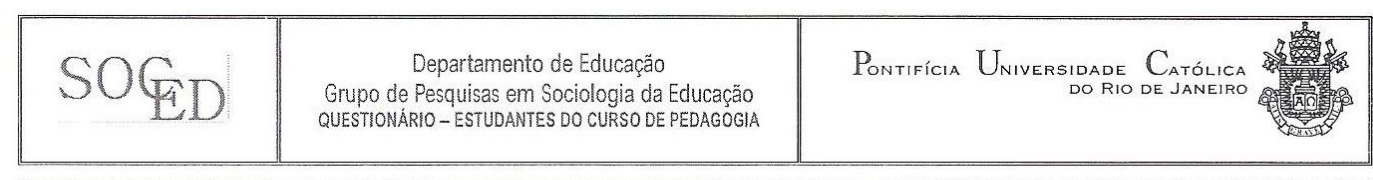

\section{ETIQUETA DE IDENTIFICAÇÃO}

\section{TRAJETÓRIA ESCOLAR}

\begin{tabular}{|c|c|c|c|}
\hline $\begin{array}{l}\text { 1. Em que tipo de instituição você cursou a maior parte do: } \\
\text { [Circule o numbro correspondente a sua resposta] }\end{array}$ & $\begin{array}{c}\text { Pública } \\
\text { (municipal/estadual) }\end{array}$ & $\begin{array}{l}\text { Pública } \\
\text { (federal) }\end{array}$ & Privada \\
\hline A. Ensino fundamental $\mathrm{I}: 1^{\circ}$ ao $5^{\circ}$ ano (antiga $1^{\mathrm{a}}$ a $4^{\mathrm{a}}$ série)? & (1) & (2) & (3) \\
\hline B. Ensino fundamental II: $6^{\circ}$ ao $9^{\circ}$ ano (antiga $5^{\mathrm{a}}$ a $8^{\mathrm{a}}$ série)? & (1) & (2) & (3) \\
\hline C. Ensino Médio? & (1) & (2) & (3) \\
\hline
\end{tabular}

\begin{tabular}{|l|}
\hline 2. Qual tipo de ensino médio você concluiu: \\
\hline (1) Ensino Médio - Curso Normal ou Magistério. \\
(2) Ensino Médio Regular (antigo $2^{\circ}$ grau). \\
(3) Ensino Médio - Curso Técnico / Profissionalizante. \\
(4) Ensino Médio - Educação de Jovens e Adultos (EJA)/Supletivo. \\
\hline
\end{tabular}

\begin{tabular}{|l|}
\hline 3. Em que turno você cursou o ENSINO MÉDIO? \\
\hline (1) Todo no diurno. \\
(2) Todo no noturno. \\
(3) Maior parte no diurno \\
(4) Maior parte no noturno.
\end{tabular}

\begin{tabular}{|c|c|c|}
\hline \multicolumn{3}{|c|}{ 4. Em que ano e semestre você ingressou no curso de PEDAGOGIA? } \\
\hline \multicolumn{3}{|c|}{ a) Ano de inicio do curso de Pedagogia: } \\
\hline b) Semestre: & (1) $1^{\circ}$ semestre & (2) $2^{\circ}$ semestre \\
\hline
\end{tabular}

\begin{tabular}{|c|c|c|}
\hline $\begin{array}{l}\text { 5. Em que turno você cursa PEDAGOGIA? [Circule o número } \\
\text { correspondentes a sta resposta] }\end{array}$ & Sim & Não \\
\hline A. Manhã & (1) & (2) \\
\hline B. Tarde & (1) & (2) \\
\hline C. Noite & $(1)$ & (2) \\
\hline
\end{tabular}

\begin{tabular}{|c|c|c|}
\hline $\begin{array}{l}\text { 6. Por que você escolheu o curso de PEDAGOGIA? [Chroule o numero } \\
\text { correspondente a sua regposta] }\end{array}$ & Sim & Não \\
\hline A. Influência da familia/amigos. & $(1)$ & (2) \\
\hline B. Já atuo/quero atuar na área de educação. & (1) & (2) \\
\hline C. Sou/quero ser professor. & (1) & (2) \\
\hline D. Menor relação candidato/vaga. & (1) & $(2)$ \\
\hline E. Admiração por antigo professor & (1) & $(2)$ \\
\hline F. Para obter diploma de curso superior. & (1) & $(2)$ \\
\hline G. Para ter outra opção profissional. & $(1)$ & (2) \\
\hline
\end{tabular}




\begin{tabular}{|l|}
\hline 7. A escolha pelo curso de PEDAGOGIA foi sua primeira opção? \\
\hline $\begin{array}{l}\text { (1) Sim (pule para pergunta 9). } \\
\text { (2) Não. }\end{array}$ \\
\hline
\end{tabular}

\begin{tabular}{|l|}
\hline 8. Se não, qual foi sua primeira opção? \\
\hline
\end{tabular}

\begin{tabular}{|c|c|c|}
\hline $\begin{array}{l}\text { 9. Você pretende trabalhar em que área? [Circule o número } \\
\text { correspondente a sua resposta] }\end{array}$ & Sim & Nãc \\
\hline A. Educação Infantil. & (1) & (2) \\
\hline B. Primeiro segmento do ensino fundamental $\left(1^{\circ}\right.$ ao $5^{\circ}$ ano). & (1) & (2) \\
\hline C. Outras áreas dentro da Pedagogia. & (1) & (2) \\
\hline \multicolumn{3}{|l|}{ 9.1 Qual: } \\
\hline D. Outras áreas fora da Pedagogia. & (1) & (2) \\
\hline 9.2 Qual: & & \\
\hline
\end{tabular}

\begin{tabular}{|l|}
\hline 10. Você é cotista? \\
\hline (1) $\operatorname{Sim}$ \\
(2) Não
\end{tabular}

CONTEXTO ESCOLAR

\begin{tabular}{|l|}
\hline 11. Se você tivesse oportunidade e condiçōes, mudaria de curso? \\
\hline (1) Sim \\
(2) Não (pule para pergunta 13).
\end{tabular}

12. Se SIM, para qual curso você mudaria?

\begin{tabular}{|l|c|c|c|c|}
\hline $\begin{array}{l}\text { 13. Avalie a relevância das disciplinas abaixo para sua formação: [Circule } \\
\text { o número correspondente a sua resposta] }\end{array}$ & $\begin{array}{c}\text { Sempre é } \\
\text { relevante }\end{array}$ & $\begin{array}{c}\text { Muitas } \\
\text { vezes é } \\
\text { relevante }\end{array}$ & $\begin{array}{c}\text { Poucas } \\
\text { vezes é } \\
\text { relevante }\end{array}$ & $\begin{array}{c}\text { Nunca é } \\
\text { relevante }\end{array}$ \\
\hline A. Fundamentos da Educação (História; Psicologia; Filosofia; Sociologia; etc.). & (1) & (2) & $(3)$ & $(4)$ \\
\hline B. Didáticas/Metodologias de ensino. & (1) & $(2)$ & $(3)$ & $(4)$ \\
\hline C. Estágios/Práticas de ensino (PPPs). & (1) & (2) & (3) & (4) \\
\hline D. Áreas de formação especifica (Ed. Infantil; Ed. Especial; EJA; etc.). & (1) & (2) & (3) & (4) \\
\hline
\end{tabular}

14. Como você avalia o domínio do conteúdo da disciplina ministrada pelos seus professores. [Circule o número correspondente a sua resposta, utilizando a escala de 1 a 10. Considere (1) se nenhum professor domina o conteúdo da disciplina e (10) se todos os professores dominam o conteúdo das disciplinas].

\begin{tabular}{cccccccccc}
$(1)$ & $(2)$ & $(3)$ & $(4)$ & $(5)$ & $(6)$ & (7) & (8) & (9) & $(10)$ \\
\hline (nenhum) & & & & & & & & (todos)
\end{tabular}




\begin{tabular}{|c|c|c|c|c|}
\hline $\begin{array}{l}\text { 15. Indique a frequência dos seguintes tipos de avaliaçăo no seu curso } \\
\text { de PEDAGOGIA: [Círcule o número correspondente a sua resposta] }\end{array}$ & Sempre & $\begin{array}{l}\text { Muitas } \\
\text { vezes }\end{array}$ & $\begin{array}{c}\text { Poucas } \\
\text { Vezes }\end{array}$ & Nunca \\
\hline A. Trabalhos/provas em grupos/seminários. & (1) & (2) & (3) & (4) \\
\hline B. Trabalho / prova individual. & (1) & (2) & (3) & (4) \\
\hline C. Participação nas aulas. & (1) & (2) & (3) & (4) \\
\hline D. Autoavaliaçäo. & (1) & (2) & (3) & (4) \\
\hline $\begin{array}{l}\text { 16. Indique a frequência do uso dos seguintes tipos de materiais durante } \\
\text { as aulas de Didática e de Metodologia de Ensino: [Circule o número } \\
\text { correspondente a sua resposta]. }\end{array}$ & Sempre & $\begin{array}{l}\text { Muitas } \\
\text { vezes }\end{array}$ & $\begin{array}{c}\text { Poucas } \\
\text { Vezes }\end{array}$ & Nunca \\
\hline A. Livros infantis. & (1) & (2) & (3) & (4) \\
\hline $\begin{array}{l}\text { B. Material concreto (material dourado, réguas de cousinaire, blocos lógicos e } \\
\text { outros) }\end{array}$ & (1) & (2) & (3) & (4) \\
\hline C. Livros didáticos. & (1) & (2) & (3) & (4) \\
\hline D. Fantoches. & (1) & (2) & (3) & (4) \\
\hline
\end{tabular}

\begin{tabular}{|l|c||c|c|}
\hline $\begin{array}{l}\text { 17. Você participa/participou dessas atividades abaixo relacionadas? } \\
\text { [Circule o número correspondente a sua resposta]. }\end{array}$ & $\begin{array}{c}\text { Sim, } \\
\text { COM bolsa }\end{array}$ & $\begin{array}{c}\text { Sim, } \\
\text { SEM bolsa }\end{array}$ & Não \\
\hline A. Projeto de extensäo. & $(1)$ & $(2)$ & $(3)$ \\
\hline B. Projeto de pesquisa. & $(1)$ & $(2)$ & $(3)$ \\
\hline C. Projeto de estimulo à docência (PIBID, PET, outros). & $(1)$ & $(2)$ & $(3)$ \\
\hline D. Monitoria. & $(1)$ & $(2)$ & $(3)$ \\
\hline E. Outras atividades acadêmicas. & $(1)$ & $(2)$ & $(3)$ \\
\hline F. Atividades administrativas na Universidade. & $(1)$ & $(2)$ & $(3)$ \\
\hline
\end{tabular}

\begin{tabular}{|l|}
\hline 18. Como você avalia o nivel de exigência do curso? \\
\hline (1) Deveria exigir MENOS. \\
(2) Deveria exigir MAIS. \\
\hline
\end{tabular}

\begin{tabular}{l}
\hline $\begin{array}{l}\text { 19. Você acredita que o seu curso desenvolve/desenvolveu um conjunto de competências que irão facilitar sua atuação como } \\
\text { professor? }\end{array}$ \\
\hline (1) Sim. \\
(2) Não. \\
\hline
\end{tabular}

\begin{tabular}{|l|c|c|c|}
\hline $\begin{array}{l}\text { 20. Indique se esses problemas influenciam a sua formação. } \\
\text { [Circule APENAS UMM numero em cada linha] }\end{array}$ & $\begin{array}{c}\text { Sim, } \\
\text { mas não foi grave }\end{array}$ & $\begin{array}{c}\text { Sim, } \\
\text { e foi muito } \\
\text { prejudicial }\end{array}$ & Năo \\
\hline A. Falta de recursos financeiros. & $(1)$ & $(2)$ & $(3)$ \\
\hline B. Falta de base escolar. & $(1)$ & $(2)$ & $(3)$ \\
\hline C. Falta de tempo para dedicar aos estudos. & $(1)$ & $(2)$ & $(3)$ \\
\hline D. Falta de apoio pedagógico (monitoria). & $(1)$ & $(2)$ & $(3)$ \\
\hline E. Falta de recursos pedagógicos. & $(1)$ & $(2)$ & $(3)$ \\
\hline F. Faltas por parte de professores. & $(1)$ & $(2)$ & $(3)$ \\
\hline G. Greve de professores. & $(1)$ & $(2)$ & $(3)$ \\
\hline H. Insuficiência de pessoal administrativo. & $(1)$ & $(2)$ & $(3)$ \\
\hline
\end{tabular}


21. Em relação ao curso de PEDAGOGIA, de forma global, você está:

(1) Muito insatisfeita(o)

(2) Insatisfeita(0).

(3) Satisfeita(0)

(4) Muito satisfeita(o).

PRÁTICAS DE ESTUDO

\begin{tabular}{|l|}
\hline 22. Você tem o hábito de estudo? \\
\hline (1) Sim. \\
(2) Năo.
\end{tabular}

\begin{tabular}{|c|c|c|c|}
\hline $\begin{array}{l}\text { 23. Indique os } 3 \text { (três) ambientes que você MAIS utiliza para estudar? } \\
\text { [Circule o número correspondente de apenas } 3 \text { dos ambientes listados } \\
\text { EM ORDEM DE MAIOR UTILIZAÇĀO] }\end{array}$ & $\begin{array}{c}1^{\circ} \text { opçäo } \\
\text { mais utilizada }\end{array}$ & $\begin{array}{c}2^{\circ} \text { opção } \\
\text { mais utilizada }\end{array}$ & $\begin{array}{l}3^{\circ} \text { opção } \\
\text { mais } \\
\text { utilizada }\end{array}$ \\
\hline A. Residência & (1) & (2) & (3) \\
\hline B. Local de trabalho & (1) & (2) & (3) \\
\hline C. Biblioteca & (1) & (2) & (3) \\
\hline D. Sala de estudo na universidade & (1) & (2) & (3) \\
\hline E. Ônibus / trem / metrô & (1) & (2) & (3) \\
\hline F. Lan house & (1) & (2) & (3) \\
\hline G. Ambientes públicos & (1) & (2) & (3) \\
\hline
\end{tabular}

24. Quanto tempo POR SEMANA você dedica ao estudo acadêmico?

horas minutos.

assisto às aulas.

(888) Não há uma regularidade. Só estudo em véspera de prova e para fazer os trabalhos.

25. Na internet, existem sites em que você busca informaçōes para seus estudos com mais frequência?

(1) $\operatorname{Sim}$

(2) Não (pule para pergunta 27).

26. Quais? [Por favor, tente citar ao menos 2 sites utilizados]

\begin{tabular}{|l|l|l|}
\hline $\begin{array}{l}\text { 27. Indique se você tem dificuldade em: } \\
\text { [Circule o número correspondente a sua resposta]. }\end{array}$ & Sim & Não \\
\hline A. Compreender os textos das disciplinas. & (1) \\
\hline B. Escrever os trabalhos. & (1) & (2) \\
\hline C. Anotar a informação dada nas aulas. & (1) & (2) \\
\hline D. Entregar os trabalhos no prazo. & (1) & (2) \\
\hline E. Ler previamente os textos indicados para as aulas. & (1) & (2) \\
\hline F. Apresentar trabalhos. & (1) & (2) \\
\hline G. Tirar dúvidas com o professor. & (1) & (1) \\
\hline
\end{tabular}


PRÁTICAS CULTURAIS/SOCIAIS

\begin{tabular}{|l|c|c|}
\hline $\begin{array}{l}\text { 28. Qual a sua atitude em relação à leitura? } \\
\text { [Circule o número correspondente a sua resposta]. }\end{array}$ & Sim & Não \\
\hline A. Só leio o que é necessário. & (1) \\
\hline B. Ler é um das minhas diversões preferidas. & (1) & (2) \\
\hline C. Acho dificil ler livros até o fim. & (1) & (2) \\
\hline D. Ler é uma perda de tempo. & (1) \\
\hline E. Adoro ir a uma livraria ou a uma biblioteca. & (1) & (2) \\
\hline \hline
\end{tabular}

\begin{tabular}{||l||}
\hline 29. Cite 3 livros que você leu, nos últimos 2 anos e gostou bastante: \\
\hline 1. \\
\hline 2. \\
\hline 3. \\
\hline
\end{tabular}

30. Você já comprou algum livro para o seu curso de PEDAGOGIA?

(1) $\operatorname{Sim}$

(2) Não (pule para pergunta 32).

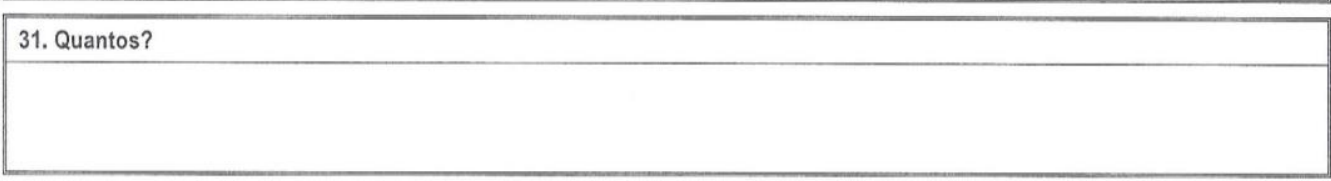

\begin{tabular}{|c|c|c|c|}
\hline $\begin{array}{l}\text { 32. Indique os } 3 \text { (três) tipos de programas de televisäo que você assiste } \\
\text { com mais frequência. } \\
\text { [Circule o numero correspondente, de } 3 \text { tipos de programas, EM ORDEM } \\
\text { DE PREFERENCIA]. }\end{array}$ & $1^{\circ}$ lugar & $2^{\circ}$ lugar & $3^{\circ}$ lugar \\
\hline A. Documentário & (1) & (2) & (3) \\
\hline B. Entrevista & (1) & (2) & (3) \\
\hline C. Esportes & (1) & (2) & (3) \\
\hline D. Filmes e/ou seriados & (1) & (2) & (3) \\
\hline E. Humoristico & (1) & (2) & (3) \\
\hline F. Jornais e noticiários & (1) & (2) & (3) \\
\hline G. Novelas & (1) & (2) & (3) \\
\hline H. Programas de auditório & (1) & (2) & (3) \\
\hline I. Reality show & (1) & (2) & (3) \\
\hline J. Religioso & (1) & (2) & (3) \\
\hline K. Shows/musicais & (1) & (2) & (3) \\
\hline
\end{tabular}




\begin{tabular}{|l|c|c|}
\hline $\begin{array}{l}\text { 33. Indique se você participa de alguma dessas atividades: } \\
\text { [Circule o número correspondente a sua resposta]. }\end{array}$ & Sim & Não participo \\
\hline A. Sindicatos. & (1) \\
\hline B. Associações (alunos, estudantes, pais, moradores). & (1) & $(2)$ \\
\hline C. Trabalho voluntário. & $(1)$ & $(2)$ \\
\hline D. Organização religiosa. & $(1)$ & $(2)$ \\
\hline E. Outro. & (1) & $(2)$ \\
\hline 33.1) Qual? (especificar o outro) & \multicolumn{2}{|}{} \\
\hline
\end{tabular}

\begin{tabular}{|l|c|c|c|c|}
\hline $\begin{array}{l}\text { 34. Com que frequência você vai aos lugares ou participa dos eventos } \\
\text { apresentados abaixo: [Clircule um número em cada linha]. }\end{array}$ & Sempre & Às vezes & Raramente & Nunca \\
\hline A. Cinema? & $(1)$ & $(2)$ & $(3)$ & $(4)$ \\
\hline B. Museus e centros culturais? & $(1)$ & $(2)$ & $(3)$ & $(4)$ \\
\hline C. Teatro? & $(1)$ & $(2)$ & $(3)$ & $(4)$ \\
\hline D. Espaços religiosos? & $(1)$ & $(2)$ & $(3)$ & $(4)$ \\
\hline E. Shows de música popular? & $(1)$ & $(2)$ & $(3)$ & $(4)$ \\
\hline F. Eventos eruditos (ópera, ballet, concertos)? & $(1)$ & $(2)$ & $(3)$ & $(4)$ \\
\hline G. Eventos esportivos? & $(1)$ & $(2)$ & $(3)$ & $(4)$ \\
\hline
\end{tabular}

\begin{tabular}{|l|}
\hline 35. Você já viajou para o exterior? \\
\hline (1) Sim. \\
(2) Não.
\end{tabular}

\begin{tabular}{|l|}
\hline 36. Qual o seu domínio da lingua inglesa? \\
\hline (1) Falo, escrevo e leio. \\
(2) Leio, mas năo falo nem escrevo. \\
(3) Praticamente nenhum. \\
\hline
\end{tabular}

\section{DADOS SOBRE A RESIDÊNCIA, FAMÍLIA E RELAÇÕES SOCIAIS}

\begin{tabular}{|l|}
\hline 37. Qual nivel de ensino seu pai concluiu? \\
\hline (1) Nenhuma escolaridade. \\
(2) Ensino fundamental: $1^{\circ}$ ao $5^{\circ}$ ano (antiga $1^{\mathrm{a}}$ à $4^{\mathrm{a}}$ série). \\
(3) Ensino fundamental: $6^{\circ}$ ao $9^{\circ}$ ano (antiga $5^{\mathrm{a}}$ à $8^{\mathrm{a}}$ série). \\
(4) Ensino médio. \\
(5) Ensino superior. \\
(6) Pós-graduação.
\end{tabular}

\begin{tabular}{|l|}
\hline 38. Qual nivel de ensino sua mãe concluiu? \\
\hline (1) Nenhuma escolaridade. \\
(2) Ensino fundamental: $1^{\circ}$ ao $5^{\circ}$ ano (antiga $1^{\mathrm{a}}$ à $4^{\mathrm{a}}$ série). \\
(3) Ensino fundamental: $6^{\circ}$ ao $9^{\circ}$ ano (antiga $5^{\mathrm{a}}$ à $8^{\mathrm{a}}$ série). \\
(4) Ensino médio. \\
(5) Ensino superior. \\
(6) Pós-graduação. \\
\hline
\end{tabular}


39. Qual a renda mensal de sua familia? [Considere a renda de todos os que moram com você].

(1) Até 1 salário minimo $(R \$ 678,00)$

(2) Até 1,5 salário mínimo (até R\$1.017,00).

(3) Acima de 1,5 até 3 salários mínimos (R\$ 1.017,00 a R\$2.034,00).

(4) Acima de 3 até 4,5 salários minimos ( $R \$ 2.034,00$ a R\$ $3.051,00$ ).

(5) Acima de 4,5 até 6 salários mínimos ( $R \$ 3.051,00$ a $R \$ 4.068,00)$.

(6) Acima de 6 até 10 salários mínimos (R\$ 4.068,00 a R\$ 6.780,00).

(7) Acima de 10 (mais de $R \$ 6.780,00$ ).

\begin{tabular}{l}
\hline 40. Quem é o (a) principal responsável financeiro (a) de sua familia? \\
(1) Você mesmo(a) \\
(2) Cônjuge \\
(3) Pai \\
(4) Mãe \\
(5) Pai e Mãe \\
(6) Outra pessoa (siga para a questão 40.1). \\
\hline
\end{tabular}

40.1. Se você marcou outra pessoa, por favor, especifique quem é o responsável:

41. Até que nivel de ensino o principal responsável financeiro de sua familia estudou?

(1) Nenhuma escolaridade.

(2) Ensino fundamental: $1^{\circ}$ ao $5^{\circ}$ ano (antiga $1^{\mathrm{a}}$ à $4^{\mathrm{a}}$ série).

(3) Ensino fundamental: $6^{\circ}$ ao $9^{\circ}$ ano (antiga $5^{\mathrm{a}}$ à $8^{\mathrm{a}}$ série).

(4) Ensino médio.

(5) Ensino superior.

(6) Pós-graduação.

42. Em relação ao custeio dos seus estudos:

(1) Sou inteiramente responsável (pule para pergunta 44).

(2) Recebo bolsa.

(3) Sou financiado por familiares (pule para pergunta 44).

(4) Outros (especificar): (pule para pergunta 44).

\begin{tabular}{|l|}
\hline 43. Se você recebe/recebeu bolsa de estudo, por quantos semestres você recebeu? \\
\hline semestre(s)
\end{tabular}

\begin{tabular}{|l|}
\hline 44. Você é casada (o)? \\
(1) Sim. \\
(2) Não. \\
\hline
\end{tabular}

\begin{tabular}{|l|}
\hline 45. Você tem filhos? \\
\hline (1) Sim. (Siga para a questão 45.1) \\
(2) Não.
\end{tabular}




\title{
45.1. Quantos?
}

46. Quanto tempo de conduçăo você gasta por dia?

[Calcule o tempo médio de translado diário completo, de ida e volta de casa para o trabalho elou para a universidade].

horas minutos.

47. Quantas pessoas moram com você?

\begin{tabular}{|c|c|c|}
\hline $\begin{array}{l}\text { 48. Qual é a sua situação atual de moradia? } \\
\text { [Circule um número em cada linha]. }\end{array}$ & Sim & Não participo \\
\hline A. Moro sozinho & (1) & (2) \\
\hline B. Com o pai & (1) & (2) \\
\hline C. Com a mãe & (1) & (2) \\
\hline D. Com o cônjuge & (1) & (2) \\
\hline E. Com os filhos & (1) & (2) \\
\hline \multicolumn{3}{|l|}{ 48.1. Quantos? } \\
\hline F. Em casa de familiares & (1) & (2) \\
\hline G. Residência de estudantes & (1) & (2) \\
\hline H. Com irmã(o) & (1) & $(2)$ \\
\hline \multicolumn{3}{|l|}{ 48.2. Quantos? } \\
\hline I. Outros. & (1) & (2) \\
\hline
\end{tabular}

49. Qual a data do seu nascimento?

$I / 19$

\begin{abstract}
50. Qual é o seu sexo?
(1) Feminino

(2) Masculino
\end{abstract}

51. A sua cor ou raça é:

(1) Branco

(2) Preto

(3) Amarelo

(4) Pardo

(5) Indigena

52. Qual é o CEP da sua residência? [Se você não souber indique a rua, bairro e cidade] 


\begin{tabular}{|c|c|c|c|c|c|}
\hline \multicolumn{6}{|c|}{$\begin{array}{l}\text { 53. Aponte a quantidade dos seguintes itens existentes na sua casa: } \\
\text { [Circule um número em cada linha]. }\end{array}$} \\
\hline \multirow[b]{2}{*}{ A. Televisão } & \multicolumn{5}{|c|}{ Quantidade } \\
\hline & (0) & (1) & (2) & (3) & $(4 \mathrm{ou}+)$ \\
\hline B. Rádio & (0) & (1) & (2) & (3) & $(4 \mathrm{ou}+)$ \\
\hline C. Banheiro & (0) & (1) & (2) & (3) & $(4 \mathrm{ou}+)$ \\
\hline D. Automóvel & (0) & (1) & (2) & (3) & $(4 \mathrm{ou}+)$ \\
\hline E. Computador & (0) & (1) & (2) & (3) & $(4 \mathrm{ou}+)$ \\
\hline F. Máquina de lavar & (0) & (1) & (2) & (3) & $(4 \mathrm{ou}+)$ \\
\hline G. DVD & (0) & (1) & (2) & (3) & $(4$ ou +$)$ \\
\hline H. Geladeira & (0) & (1) & (2) & (3) & $(4 \mathrm{ou}+)$ \\
\hline I. Freezer (independente ou em geladeira duplex) & (0) & (1) & (2) & (3) & $(4 \mathrm{ou}+)$ \\
\hline
\end{tabular}

SITUAÇÃO PROFISSIONAL ATUAL

\begin{tabular}{|l|}
\hline 54. Você faz estágio? \\
\hline (1) Não. \\
(2) Sim, NÄO remunerado. \\
(3) Sim, remunerado. \\
\hline
\end{tabular}

\title{
55. Você trabalha?
}

(1) Sim.

(2) Não [Fim do questionário. Obrigado].
56. Em qual área?
(1) Sou professor (a). (pule para pergunta 58)
(2) Trabalho na área de educação fora da sala de aula. (pule para pergunta 58)
(3) Trabalho em outra área. 56.1. Qual?

\author{
57. Qual seu regime de trabalho? \\ (1) Tempo parcial. \\ (2) Tempo integral.
}

\section{Obrigado por sua colaboraçäo!}

